US Army Corps

of Engineers

Construction Engineering

Research Laboratories

\title{
REMR Management SystemsC BREAKWATER Computer Program User Manual (Version 1.0)
}

by Ricardo Aguirre

U.S. Army Construction Engineering

Research Laboratories

Don Plotkin

U.S. Army Construction Engineering

Research Laboratories 


\section{REMR Management SystemsC BREAKWATER Computer Program User Manual (Version 1.0)}

by Ricardo Aguirre

Research Assistant

U.S. Army Construction Engineering Research Laboratories

PO Box 9005

Champaign, Illinois 61826-9005
Don Plotkin

Civil Engineer

U.S. Army Construction Engineering

Research Laboratories

PO Box 9005

Champaign, Illinois 61826-9005

Approved for public release; distribution is unlimited.

Prepared for U.S. Army Corps of Engineers

Washington, DC 20314-1000

Under

Civil Works Research Work Unit 32673

Monitored by Maintenance Management and Preservation Division U.S. Army Construction Engineering Research Laboratories

PO Box 9005, Champaign, IL 61826-9005 


\section{Contents}

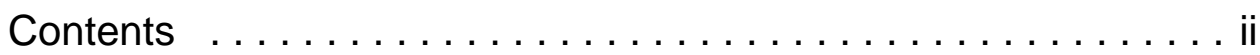

Preface $\ldots \ldots \ldots \ldots \ldots \ldots \ldots \ldots \ldots \ldots \ldots \ldots$ iv

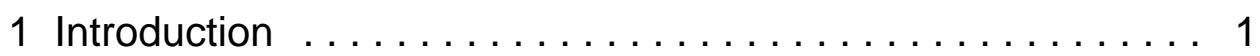

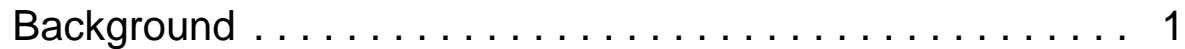

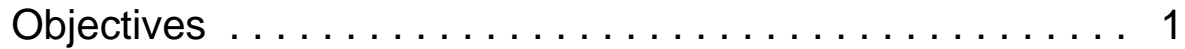

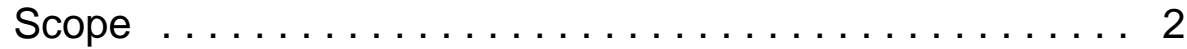

Approach .......................... 2

Mode of Technology Transfer ................ 2

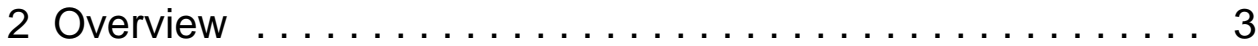

Program Description ................. 3

Breakwater's Major Components ............. 3

General Program Operation and Arrangement ........ 5

Manual and Program Conventions .............. 7

Program Operation Keys: Functions and Conventions .... 8

Program Help: The F1 Key $\ldots \ldots \ldots \ldots \ldots \ldots \ldots$

Using a Mouse $\ldots \ldots \ldots \ldots \ldots \ldots \ldots \ldots \ldots \ldots$

Multiple Program Operation $\ldots \ldots \ldots \ldots \ldots \ldots \ldots .10$

3 Program Installation and Setup $\ldots \ldots \ldots \ldots \ldots \ldots \ldots \ldots \ldots$

Introduction ................... 11

Hardware Requirements $\ldots \ldots \ldots \ldots \ldots \ldots \ldots \ldots 11$

Computer Configuration $\ldots \ldots \ldots \ldots \ldots \ldots \ldots \ldots \ldots 12$

Installing BREAKWATER $\ldots \ldots \ldots \ldots \ldots \ldots \ldots \ldots \ldots \ldots$

Starting BREAKWATER $\ldots \ldots \ldots \ldots \ldots \ldots \ldots \ldots \ldots 13$

BREAKWATER Setup Options $\ldots \ldots \ldots \ldots \ldots \ldots \ldots .13$

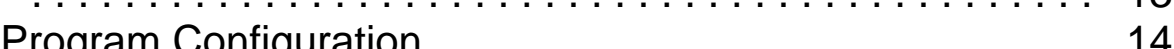

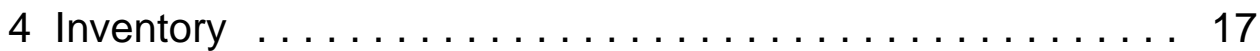

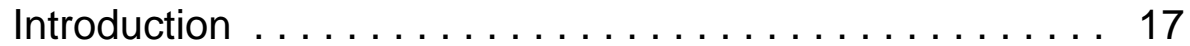

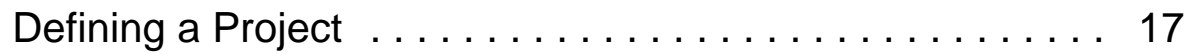

Editing/Deleting a Project $\ldots \ldots \ldots \ldots \ldots \ldots \ldots \ldots \ldots$

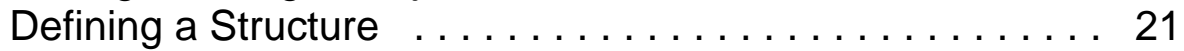

Editing and Deleting a Structure $\ldots \ldots \ldots \ldots \ldots \ldots 23$

Defining a Reach ...................... 24

Editing/Deleting a Reach . . . . . . . . . . . . 26 


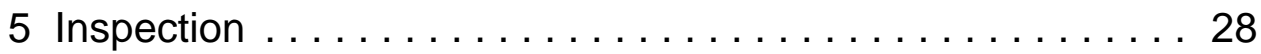

Adding Inspection Data $\ldots \ldots \ldots \ldots \ldots \ldots \ldots 28$

Modifying Inspection Data . . . . . . . . . . . . . 32

Modes ............................. 32

Change Modes $\ldots \ldots \ldots \ldots \ldots \ldots \ldots \ldots \ldots \ldots \ldots \ldots \ldots \ldots$

Comments ........................ 33

Structural Data . . . . . . . . . . . . . . . . 34

Reach Stations, Suggested Actions, Comments . . . . . . 36

Additional Data . . . . . . . . . . . . . . . . . . 37

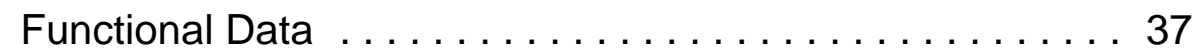

Other Functions $\ldots \ldots \ldots \ldots \ldots \ldots \ldots \ldots \ldots \ldots \ldots$

6 Reports and Forms .................... 40

General Organization and Operation . . . . . . . . . . 40

District Inventory Summary . . . . . . . . . . . . . . 41

Condition Index Calc: Reach . . . . . . . . . . . . 41

Historical Rating Summary $\ldots \ldots \ldots \ldots \ldots \ldots \ldots \ldots 42$

Comment Report: Reach . . . . . . . . . . . . . . . 43

Missing Information Report $\ldots \ldots \ldots \ldots \ldots \ldots \ldots \ldots 44$

Print Inspection Forms $\ldots \ldots \ldots \ldots \ldots \ldots \ldots \ldots .44$

7 Database Administration $\ldots \ldots \ldots \ldots \ldots \ldots \ldots \ldots$

Introduction ....................... 46

Selecting a Database . . . . . . . . . . . . . 46

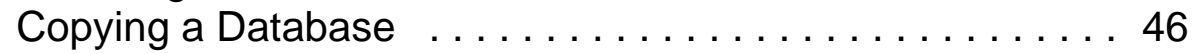

Deleting a Database ................... 48

Merging Two Databases . . . . . . . . . . . . 48

Reorganizing a Database $\ldots \ldots \ldots \ldots \ldots \ldots \ldots . \ldots 49$

Creating a Database ................... 50

Appendix A: Reports . . . . . . . . . . . . . . 51

Appendix B: Forms $\ldots \ldots \ldots \ldots \ldots \ldots \ldots \ldots \ldots \ldots 9$ 


\section{Preface}

The computer program described herein was authorized by Headquarters, US Army Corps of Engineers (HQUSACE), as part of the Operations Management problem area of the Repair, Evaluation, Maintenance, and Rehabilitation (REMR) Research Program. This work was performed as part of Civil Works Research Work Unit 32673 "Development of M\&R Guidelines and Management Systems for Civil Work Structures" Mr. Don Plotkin is the Principal Investigator and Mr. Harold Tohlen (CECW-O) is the REMR technical monitor for this work.

Mr. David B. Mathis (CERD-C) is the REMR Coordinator at the Directorate of Research and Development, HQUSACE; Mr. Tohlen and Dr. Tony C. Liu (CECW-EG) serve as the REMR Overview Committee; Mr. William McCleese (CEWES-SC-A), US Army Engineer Waterways Experiment Station (WES), is the REMR Program Manager; Dr. Paul Howdyshell is the Problem Area Leader for the Operations Management problem area.

This work was conducted by the US Army Construction Engineering Research Laboratories, Facilities Technology Laboratory, Maintenance Management and Preservation Division (FL-P). Dr. Simon Kim is FL-P Division Chief.

The authors gratefully acknowledge the assistance of the Coastal Structure Advisory Group and many others throughout the Corps' coastal community whose excellent ideas helped guide this work.

COL James A. Walter is Commander of USACERL, and Dr. Michael J. O'Connor is Director. 


\section{Introduction}

\section{Background}

In an effort to improve maintenance techniques and practices for inland waterway and coastal structures, the U.S. Army Corps of Engineers (USACE) established the Repair, Evaluation, Maintenance, and Rehabilitation Research (REMR) program. Within the REMR program is a group of projects dedicated to the development of computerized maintenance management systems for coastal and inland waterway navigational structures. The general intent of these REMR Management Systems is to provide maintenance managers at all levels with tools to promote easier and more effective maintenance and budget planning. Additional objectives are to create uniform procedures for assessing the condition of structures and to create assessment methods that will allow the condition of structures, and their parts, to be expressed numerically to take best advantage of the benefits available from the use of microcomputers in maintenance management.

The computer program described here is the initial version of the computer program for maintenance management of coastal structures. This version is a companion program for the Condition and Performance Rating Procedures for Rubble Breakwaters and Jetties, developed as part of REMR Work Unit 32672.

\section{Objectives}

The objectives of this phase of the project were to produce a computer program which would:

1. Allow the establishment of a database of rubble breakwaters and jetties.

2. Allow the collection of structure inspection and rating information, as required by the condition and performance rating procedures for rubble breakwaters and jetties developed under REMR Work Unit 32672.

3. Calculate Structural Index (SI), Functiponal Index (FI), and Condition Index (CI) values.

4. Produce a selection of reports showing inventory, inspection, and index data.

This manual describes the operation of the BREAKWATER program, version 1.0, which contains the basic features described in items (a) through (d) above. 


\section{Scope}

The computer program described here represents the first stage in developing a maintenance management system for coastal navigation and protection structures. The computer software (currently called BREAKWATER) is a DOS-based program intended to handle the most basic maintenance management functions and calculate the required index values.

This initial program concentrates on breakwaters and jetties of rubble construction with either rock or concrete armor units. Future efforts will include system features for breakwaters and jetties of nonrubble construction and also seawalls, bulkheads, and revetments, as well as other desired management functions. Future versions of the program will be Windows-based and otherwise consistent with the most current operating and network systems in use at that time.

\section{Approach}

As a companion program to the condition and performance rating procedures for rubble breakwaters and jetties (developed under REMR Work Unit 32672), the program screens were made to closely match the inspection and rating forms developed for the field and office ratings and analysis. The method for calculating the index values is as described in the manual on "Condition and Performance Rating Procedures for Rubble Breakwaters and Jetties."

\section{Mode of Technology Transfer}

This manual is the primary means of technology transfer. As time and funding permit, program demonstrations and short classes will occasionally be conducted. 


\section{Overview}

\section{Program Description}

This is the initial version of BREAKWATER - the REMR management system computer program for coastal structures. It was developed as part of the REMR (Repair, Evaluation, Maintenance, and Rehabilitation) research program (Work Unit 32673) sponsored and guided by the U.S. Army Corps of Engineers Directorate of Civil Works - Operations and Readiness Division.

This initial DOS-based version handles basic structural and functional information, reporting, and Condition Index (CI) calculations for rubble (or primarily rubble) breakwaters and jetties, with either rock or concrete armor units. It is a companion program for the manual on Condition and Performance Rating Procedures for Rubble Breakwaters and Jetties, also produced under the REMR program.

It is intended that future versions of BREAKWATER will be expanded to cover other types of coastal structures and to incorporate other modules and features needed to assist with maintenance management of these structures. Future versions will also include updated software.

\section{Breakwater's Major Components}

There are four components to the BREAKWATER Program.

\section{Inventory}

Inventory is the set of data that describes the location, dimensions, and general construction characteristics of each structure. It also indicates the division of the structures into reaches, the functions each structure (or reach) is intended to perform, and which Corps project the structure is part of. For each structure, a completed inventory data set defines that structure within the program so that all subsequent inspection and condition information can be properly associated with it. Details are in Chapter 3.

\section{Inspection}

Inspection is data that describes the physical condition and functional performance of a structure. Most inspection entires are either structural and functional numerical ratings (from which the 
program calculates Condition Indexes) or comments that explain the rating choices and document other observations about the structure. Screens in the Inspection component follow the same format as the structural and functional rating forms used by inspectors and engineers. Details are in Chapter 4.

\section{Reports and Forms}

The reports and forms component offers the user a series of reports summarizing or detailing past inspections and pre-headed blank structural and functional rating forms for the next inspection and rating for a reach or structure. The Reports option contains the following five choices:

\section{District Inventory Summary}

2. Condition Index Calculation for Reaches

3. Historical Rating Summary

4. Comment Report for Reaches

5. Missing Information Report.

The Forms option contains the following five choices:

1. Blank Inspection Form

2. Date Selected Inspection Form

3. Project Selected Inspection Form

4. Structure Selected Inspection Form

5. Reach Selected Inspection Form

The forms are the same as those shown in the rating procedures manual. Details are in Chapter 5.

\section{Database Administration}

A database is a set of data for a group of coastal projects and thus typically contains data on many structures. In practice, it is expected that each Corps District will maintain one database for its structures, although smaller databases (as for Area Offices) are also possible.

The Database Administration component allows the user to perform these operations with databases:

1. Create databases (essentially giving them a name that defines them in the computer).

2. Select a database to work with.

3. Copy databases.

4. Merge databases (creates a Division database from two or more District databases). 
5. Reorganize databases (restores them in the computer to occupy disk space most efficiently).

6. Delete databases.

All of these options can be performed on databases that are on a floppy disk, a hard drive, or a network drive. Details are in Chapter 6.

\section{General Program Operation and Arrangement}

\section{Working with Data}

Before any data can be entered, viewed, or edited, a database must be chosen or created. Do this by choosing (5) Database Administration from the main menu and then choose either (1) Select a Database or (6) Create a Database from the Database Administration menu.

\section{The Two Menu Types}

BREAKWATER is menu driven; that is, most operations are initiated by choosing a selection from a menu (or list) of options. There are two types of menus in the program. They appear in the following general formats:

$\begin{array}{cc}1 & 2 \\ \text { [A] Option 1 } & \text { Main Menu } \\ \text { [B] Option 2 } & \text { Submenu } \\ \text { [C] Option 3 } & \text { Submenu 2 }\end{array}$

In either type an option may be selected by:

1. Using the arrow keys to highlight the desired option and pressing the key labeled [ENTER], or

2. Pressing the key designated as the trigger.

In column 1, the triggers are $\mathbf{A}, \mathbf{B}$, and $\mathbf{C}$. In column 2 the triggers are $\mathbf{M}, \mathbf{S}$, and $\mathbf{2}$.

\section{Entering Data}

Data entry is handled in two ways:

1. A Pop-up Menu system, where the appropriate data may be selected by the two methods described above. 
2. Typing in the information, where the size of the box indicates the amount of data that can be entered (the maximum number of characters).

\section{The Main Menu}

The program begins with the Main Menu, which provides the following options:

- $\quad$ Add/Edit Project \& Structure Inventory

- Modify/View/Delete Inspection Data

- $\quad$ Add Inspection Data

- Reports and Forms

- Database Administration

- Machine Configuration.

\section{Add/Edit Project \& Structure Inventory}

This option is used for defining structure inventory. It allows the user to describe the location, dimensions, and general construction characteristics of the projects, the structures, and the reaches. This option also allows the user to edit already defined projects, structures, and reaches.

\section{Modify/View/Delete Inspection Data}

This option (to modify, view, or delete inspection data) is a supplement to Add Inspection Data and can only be used after inspection data has been entered. This option is also useful for quickly viewing calculated Condition Index values for individual reaches and their respective structures. The user should be careful, however, when choosing Delete as there is no retrieving feature to recover data after it is deleted.

\section{Add Inspection Data}

This option is used for entering inspection data. It can only be used after the project and structure inventory have been completely defined.

\section{Reports and Forms}

This option is used for obtaining reports and forms. Reports provides organized formats for viewing or printing inventory or inspection data, comments, missing information, structural and functional ratings, and the related calculated Condition Index values. Forms provides field inspection sheets that can have blank headings or be pre-labeled with the project, structure, reach, and inspection date headings. 


\section{Database Administration}

This option is used for managing the program's databases. As with Modify/View/Delete

Inspection Data, the user should be careful when using the delete mechanism in this option; once deleted, a database cannot be recovered.

\section{Machine Configuration}

This option is used for adjusting screen colors, printer options, and program sounds. It allows the user to create a comfortable setting for working with this program and provides printing options for various printers.

\section{Manual and Program Conventions}

\section{Manual Convention}

Throughout the manual it is assumed that most entries are actuated by pressing the ENTER key. Therefore, this step will not be shown in the manual. Any exceptions will be noted.

\section{Program Conventions}

The following conventions are used with BREAKWATER:

1. The box at the bottom of the screen is the key information box. Available keys and their functions are noted in that box.

2. Most data fields must be completed to allow the program to calculate condition indexes; optional data fields are usually apparent.

3. Incomplete data sets may be saved.

4. The F10 (Done) key:

- $\quad$ May be used at any time during the operation of the program.

- $\quad$ During data entry and modification the F10 key will prompt the user to Save the data and return, Abort the data and return, or Continue editing the current data set. Upon completion of the Save or Abort, the system returns the user to the previous screen.

- $\quad$ At non-data entry and modification screens, the F10 key simply returns the user to the previous screen. 


\section{Program Operation Keys: Functions and Conventions}

\section{The Three Operation Key Types}

There are three types of keys available for use throughout BREAKWATER:

1. Data Entry Keys

2. Editing Keys

3. Specialty Keys

The functions of each type are discussed below:

\section{Data Entry Keys}

The data entry sections of BREAKWATER use a number of keys for cursor movement, data selection, and special functions. The system employs two different methods for data entry. The first involves selection of data from a pop-up menu (Type 1). The second requires the user to key in the data (Type 2). Key availability and function is displayed in a box at the bottom of the screen.

\begin{tabular}{|c|c|c|c|}
\hline Key Name & Symbol & \multicolumn{2}{|c|}{ Function } \\
\hline Enter Key & [ENTER] & \multicolumn{2}{|c|}{ Accepts the data and moves cursor to the next data field. } \\
\hline Home Key & Home & \multicolumn{2}{|c|}{ Places cursor on the first data entry field. } \\
\hline End Key & End & \multicolumn{2}{|c|}{ Places cursor on the last data entry field. } \\
\hline \multirow[t]{2}{*}{ Up Arrow Key } & $\uparrow$ & Type 1: & Moves the highlight bar up one menu option. \\
\hline & & Type 2: & Places the cursor on the data entry field above the current field. \\
\hline \multirow[t]{2}{*}{ Down Arrow Key } & $\downarrow$ & Type 1: & Moves the highlight bar down one menu option. \\
\hline & & Type 2: & Places the cursor on the data entry field below the current field. \\
\hline \multirow[t]{2}{*}{ Right Arrow Key } & $\rightarrow$ & Type 1: & Moves the highlight bar down or to the right one menu option. \\
\hline & & Type 2: & Places the cursor on the next data entry field. \\
\hline \multirow[t]{2}{*}{ Left Arrow Key } & $\leftarrow$ & Type 1: & Moves the highlight bar up or to the left one menu option. \\
\hline & & Type 2: & Places the cursor on the previous data entry field. \\
\hline F1 Key & F1 & \multicolumn{2}{|c|}{ Displays help screen. } \\
\hline F2 Key & F2 & \multicolumn{2}{|c|}{$\begin{array}{l}\text { Functions as a Type } 2 \text { up arrow key, and a Type } 1 \text { and Type } 2 \text { entry only on those } \\
\text { screens that apply. }\end{array}$} \\
\hline F3 Key & $\mathbf{F 3}$ & \multicolumn{2}{|c|}{$\begin{array}{l}\text { Functions as a Type } 2 \text { down arrow key, and a Type } 1 \text { and Type } 2 \text { entry only on those } \\
\text { screens that apply. }\end{array}$} \\
\hline F10 Key & F10 & \multicolumn{2}{|c|}{ F10 always exits the current process and returns the user to the previous one. } \\
\hline
\end{tabular}




\section{Editing Keys}

The following editing keys are used mainly when making changes to the data already entered into the program:

\begin{tabular}{lll} 
Key Name & Symbol & Function \\
\hline Backspace Key & $\leftarrow$ & Backward one space (erases characters as it moves) \\
Delete Key & DEL & Deletes the character at the cursor position \\
Insert Key & INS & Toggles the Insert Mode on / off \\
Left Arrow Key & $\leftarrow$ & Backward one space (moves without erasing characters) \\
Right Arrow Key & $\rightarrow$ & Forward one space (moves without erasing characters) \\
\hline
\end{tabular}

\section{Specialty Keys}

Function Keys F2, F3 and F4 perform different actions at different locations in the system. During the editing process they function as described above. At other times the actions are listed at the bottom of the screen in the key box.

\section{Program Help: The F1 Key}

Program Help was created for user convenience, and supports most screens in the BREAKWATER program. When activated, the F1 Key provides the user with a description of the highlighted option displayed on the current screen. If F1 Help is activated on a menu screen, such as the main menu of the program, it will remain on until an option is chosen. This allows the user to scroll down the menu to see a description of each option.

If a screen is not supported by F1 help, then pressing the F1 key defaults to the system help box. The system help box gives a listing of the Breakwater and computer program definitions. In addition to the definitions, the system help provides tutorials on the major procedures for inventory and inspection. The user may want to skim the system help box and review the provided tutorials for brief step by step procedures on how to input data into this system.

\section{Using a Mouse}

The mouse acts as a supplement to the keyboard, and can be used in almost all of the screens. The mouse has the same point and click features in this program as all other Windows type programs. However, the cursor for the mouse will not be an arrow like most windows programs, but rather a block that takes up the space of one character. Like other Windows-type programs, 
you are able to point anywhere in a screen and click to insert your entry or select a menu option. In some screens, however, the mouse is not activated.

\section{Multiple Program Operation}

Due to the origination and development as a DOS based program, Breakwater is best run with few or no resident programs open. Lack of memory might cause the BREAKWATER program to produce a fatal error if too many other computer programs are being run at the same time. 


\section{Program Installation and Setup}

\section{Introduction}

This chapter will explain the steps required prior to entering data into BREAKWATER. The following topics will be covered:

- Hardware Requirements

- Computer Configuration

- Installing BREAKWATER

- $\quad$ Starting BREAKWATER

- $\quad$ BREAKWATER Setup Options.

\section{Hardware Requirements}

BREAKWATER was developed for operation on an IBM ('Thternational Business Machines Corp.) compatible personal computer that runs at least MS-DOS 3.3 (TMicrosoft Corp.). A hard disk drive is required with a recommended 20 megabytes or higher free storage capacity. 4 megabytes of Extended Memory is required to run this version of the program. 640K RAM memory is also required.

If the computer has memory resident utilities such as Sidekick or PC Tools loaded into memory, they may need to be unloaded before BREAKWATER can be run.

If BREAKWATER is to be run on an older (slower) PC, a system for disk caching is highly recommended. There are many utilities, shareware and otherwise, available which can improve disk performance substantially. We warrant no caching system to perform with this program other than SMARTDRIVE. 


\section{Computer Configuration}

A file called CONFIG.SYS must be present in the root directory of the PC with the following commands for this program to run properly.

\section{BUFFERS $=25$}

FILES $=25$

The CONFIG.SYS file can be detected by typing DIR CONFIG.SYS in the root directory. If the file exists, the PC will list the file name, size and date created. If you do not have a CONFIG. SYS file, use a text editor (not a word processor unless the information can be saved in text format) to create one with the above commands. Place the file in the root directory of the PC. After creating a new CONFIG.SYS, restart the PC (CTRL-ALT-DEL). To ensure that the PC has at least $640 \mathrm{~K}$ of available RAM memory, type the command CHKDSK at the C:l> prompt to receive a disk and memory status report. The last two lines displayed on the screen should read:

\section{\# BYTES TOTAL MEMORY \\ \# BYTES FREE}

The number of bytes total memory should be at or near $640 \mathrm{~K}$. The number of bytes free should be near $511 \mathrm{~K}$ or greater. If it is not, check for the presence of a memory resident utility. For further explanation concerning CONFIG.SYS, BUFFERS, and FILES commands, consult a DOS manual.

\section{Installing BREAKWATER}

BREAKWATER will be supplied on floppy disk. All the files will be copied onto the local hard drive when the program is installed. A summary of the install procedure follows (while in DOS):

1. Insert the floppy disk labeled Disk \#1 into the PC's A: drive.

2. Type A:install at the $\mathrm{C}: \mathrm{l}>$ prompt.

3. Follow the instructions displayed on the screen. Choose BRKWATR as your subdirectory.

When the install process is complete BREAKWATER is on your local hard drive in a directory called BRKWATR, as you have chosen. 


\section{Starting BREAKWATER}

When you are ready to access BREAKWATER, you must be in the BRKWATR directory.

1. Access the BREAKWATER directory. At the system prompt type:

C:I>CD BRKWATR

2. Type the command BWMAIN after the system prompt.

C:|BRKWATR>

The first BREAKWATER screen will now appear.

\section{BREAKWATER Setup Options}

After BREAKWATER is invoked with the command C:IBRKWATR> BWMAIN, and a password is given, the main menu is displayed. All options begin at this menu.

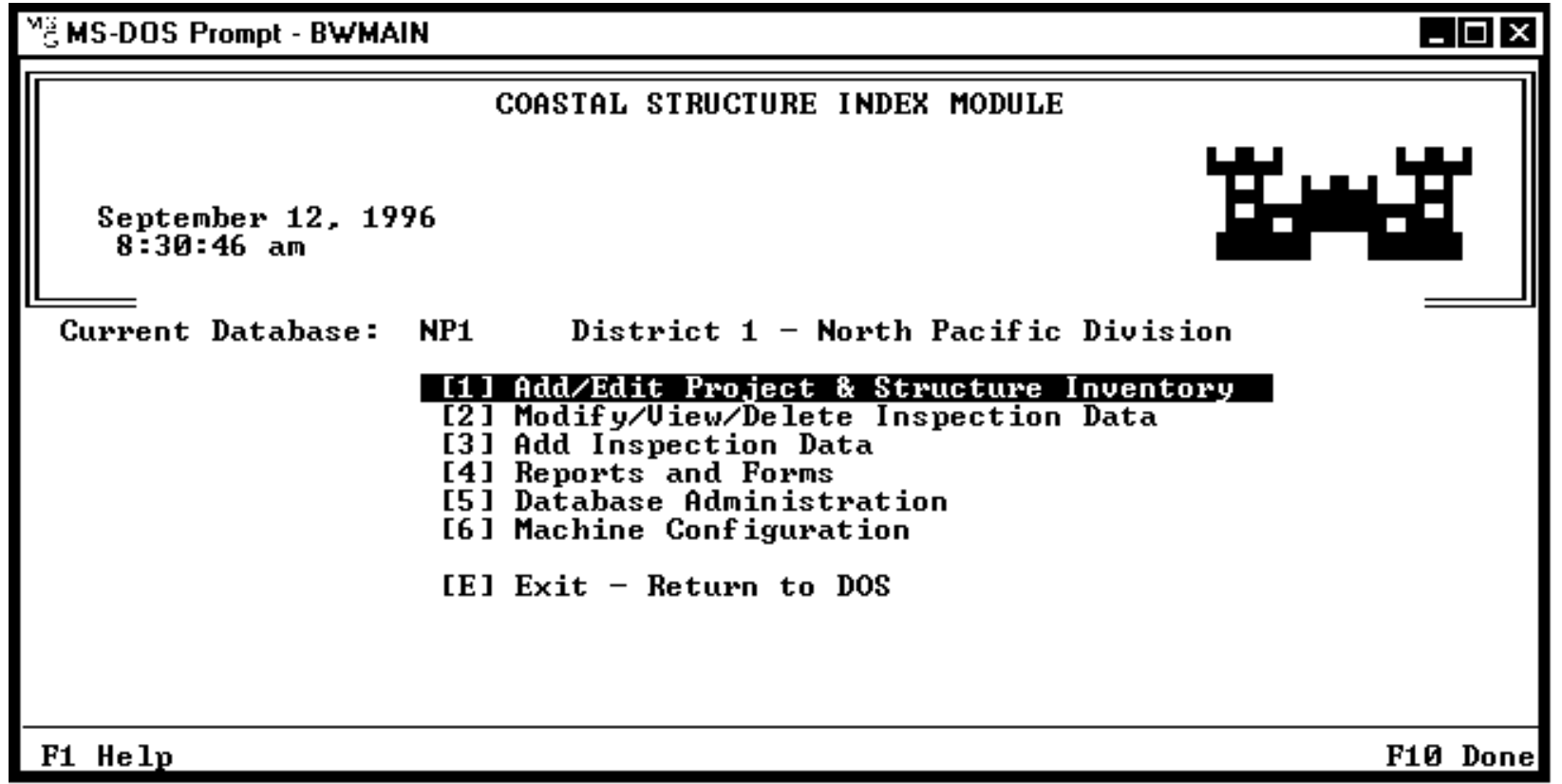




\section{Program Configuration}

When using BREAKWATER on a color monitor, the ability to specify foreground and background colors, as well as printer types has been provided in the Machine Configuration, option 6 , from the main menu. The machine configuration option provides a menu driven method for the user to modify the default settings for a number of different display characteristics. When the Machine Configuration Menu of each new selection is displayed, the current setting is shown as the default.

\section{-Breakwater PC Configuration Menu}

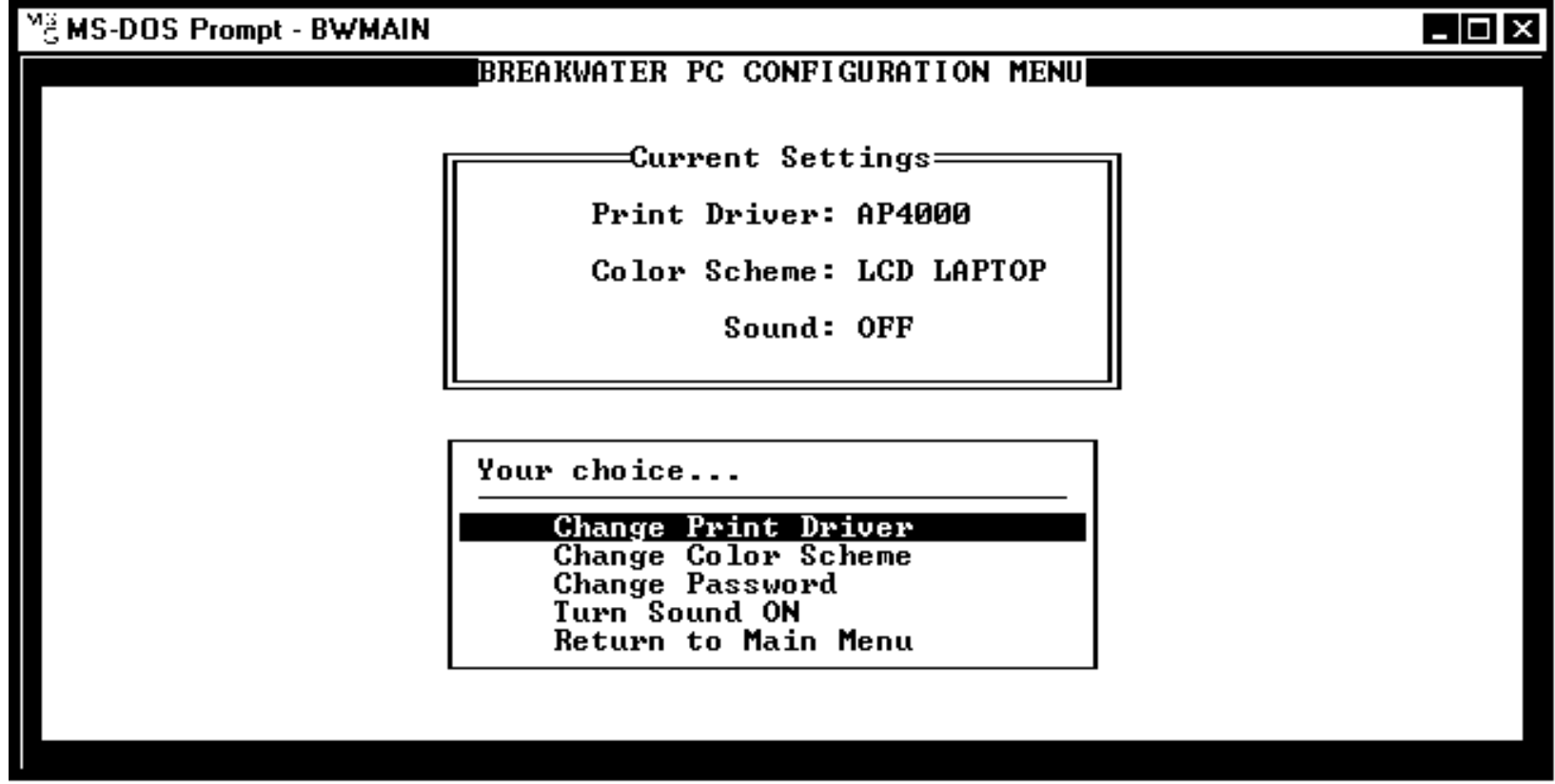




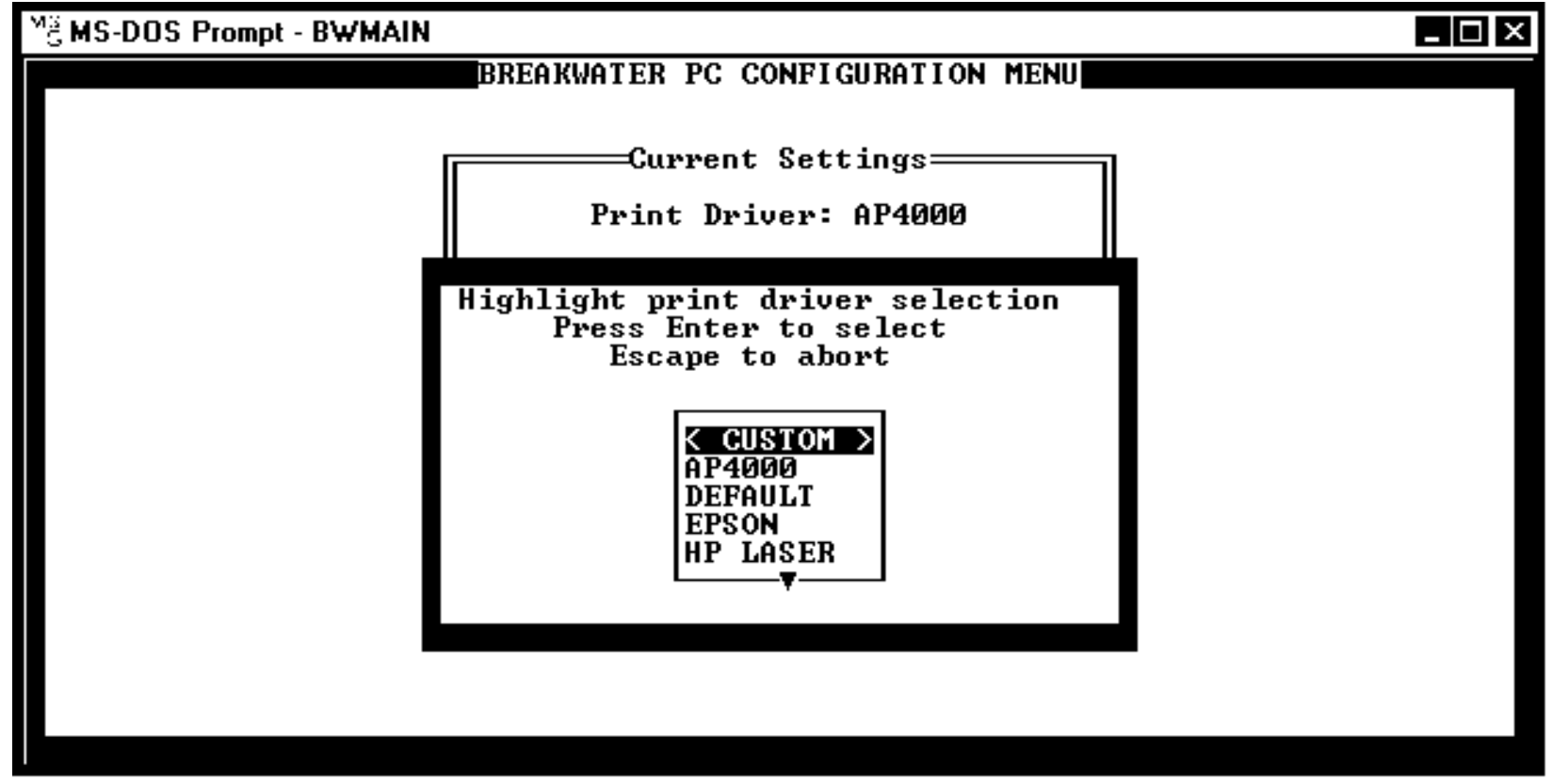

The system must be configured for the proper printer to print the reports and forms.

BREAKWATER provides the parameters for six predefined printers. These are: HP LaserJet, Epson, Null, AP4000, Okidata, and an IBM printer. If the appropriate printer is not available in the above listing, a fifth option, CUSTOM is provided. When selecting CUSTOM the user must supply the system with two pieces of information about the printer. First, a user defined printer name is necessary for reference by the program (i.e., 'IBM PROPRINTER'). Second, you must enter the printer codes manually. See your Printer Operating Manual for instructions on how to do this.

\section{- $\quad$ Screen Configuration}

The system has the ability to work with color or monochrome screens. These can be selected via the screen configuration menu.

\section{- $\quad$ Screen Colors}

The foreground and background colors may be specified for the following displays: titles, boxes, text, highlighted text, error messages, pop-up boxes, triggers, data, highlight (menu) bars, and fields. The possible color choices are selected from a menu. They are: Blue/Gold, Blue/Green, Blueline, Gas Plasma, Green/Gray, LCD Laptop, Monochrome, and Rainbow. The user should try out each color scheme to see which one is the most preferable.

The arrow keys are used to maneuver the menu bar over the desired color scheme, and the carriage return is used to select it. Also, the user is able to select any color scheme by clicking on it with the left mouse button. As the colors are changed the main selection menu acts as a 
sample box, and reflects the user's new choices. Upon completion, the new colors may be stored by pressing the F10 key and answering $\mathbf{Y}$ to the store changes prompt. From this point forward the Coastal Structure Module will reflect the new colors chosen by the user.

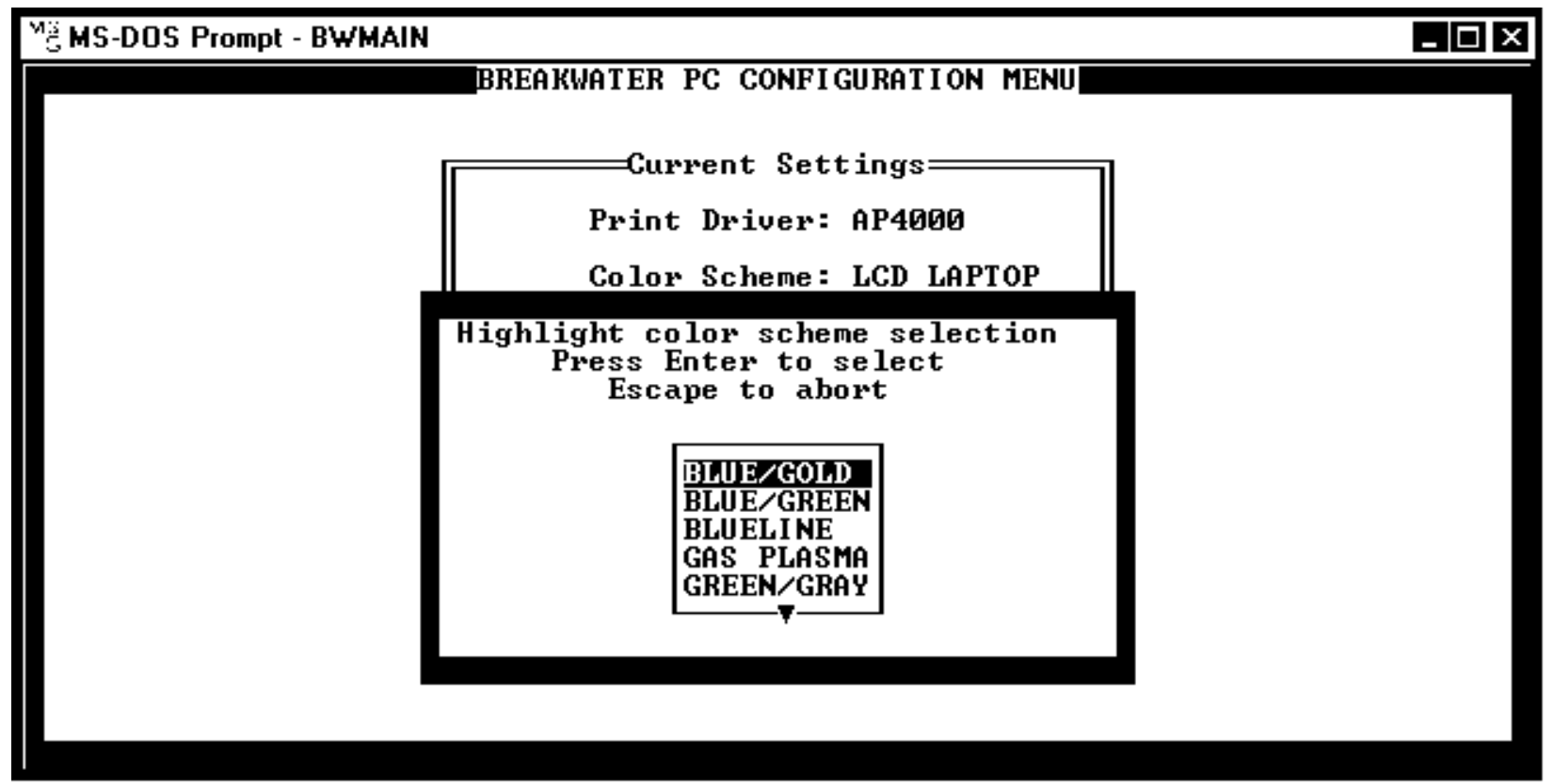




\section{Inventory}

\section{Introduction}

Inventory information defines the projects and structures within the program database. This information must be entered before any inspection data can accepted by the program. Inventory is divided into these three types of data:

- $\quad$ Project Data

- Structure Data

- $\quad$ Reach Data

\section{Defining a Project}

To add (define) a project:

- $\quad$ Select Add/Edit Project \& Structure Inventory, option 1, from the Main Menu.

The following screen will appear-the Project/Structure/Reach Menu.

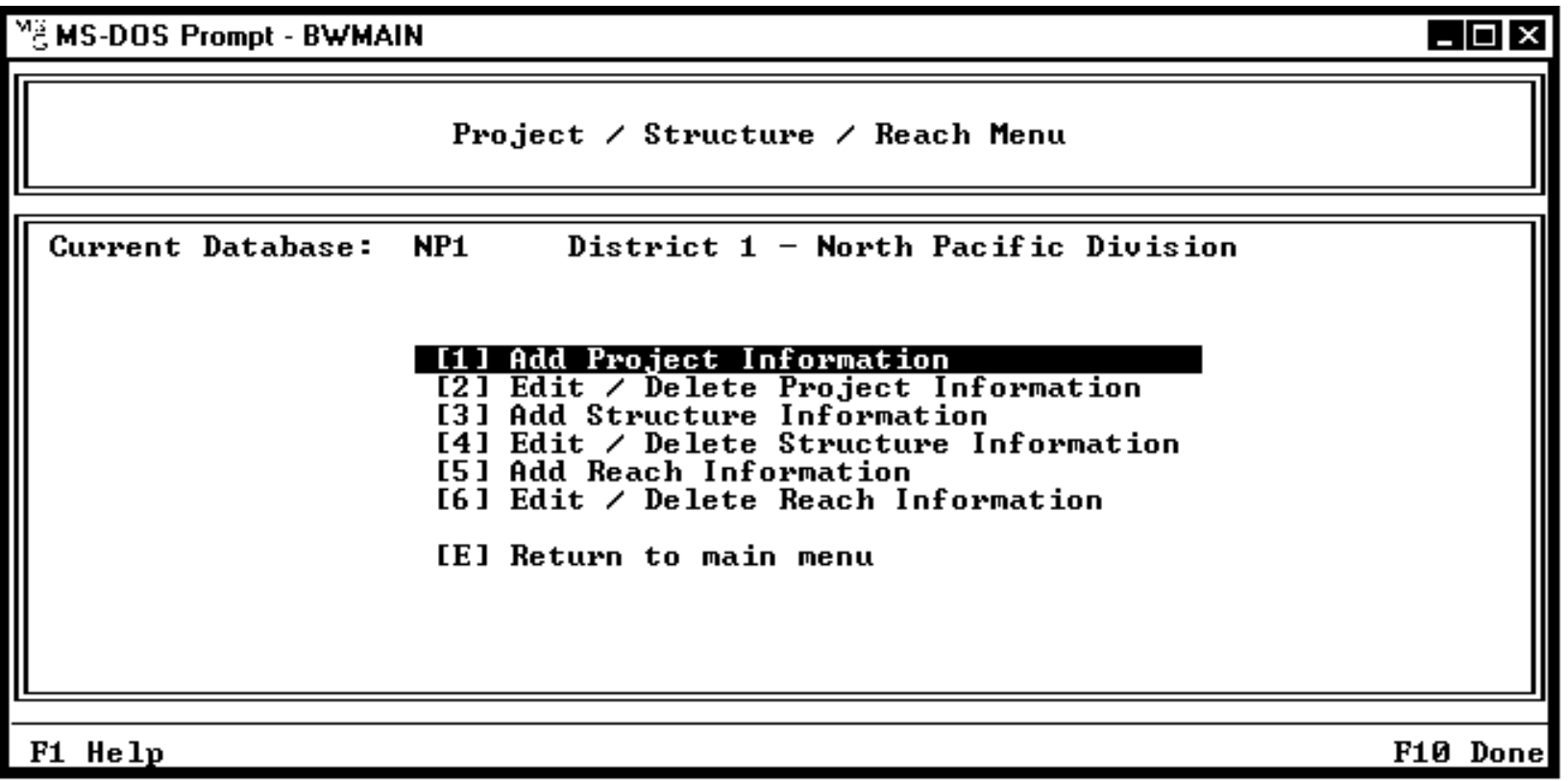

- $\quad$ Select Add Project Information, Option 1. 
The Add Project screen will appear.

MË MS-DOS Prompt - BW/MAIN

\section{Add Project}

Project Name: -

Project Number:

\section{District :}

City:

Protected Waters:

Authority:

office File:
Division:

State:

Owner:

Congress:

F1 Help F2 †Fld F3 ŁFld

The following data should be entered for each project:

Project Name: Name of project. It is the name under which the structures are listed.

Project Number: The number that corresponds to the project and distinguishes it from other projects.

District: $\quad$ The USACE district where the project is located.

Division: $\quad$ A three-letter abbreviation of the division where the project is located. (i.e. SPD - South Pacific Division).

City: $\quad$ The city where the structure is located.

State: $\quad$ The state where the structure is located.

Protected Waters: The body of water that the structure is protecting: harbor, channel, etc.

Authority: The legislative authority that led to the construction and maintenance of the project.

Owner: The owner of the project may be a public or government agency.

Office File: The number that corresponds to an office file of the project. 
Congress: $\quad$ The congressional district where the project is located. This field has two parts. The first part is automatically entered by BREAKWATER and is the two-letter state abbreviation supplied in the State field. The second part is a three digit number. This number is user-supplied.

The following keys can be used to move the cursor on the screen:

Arrow Keys Move the cursor from field to field around the screen.

Home/End Moves the cursor to the first / last field on the screen.

F2 Acts the same as the up arrow key.

F3 Acts the same as the down arrow key.

After entering the Congressional District Number, BREAKWATER will automatically save the record if all the information was entered correctly. If data is missing in the Project Name field or the Project Number field or both, a warning box pops up and the user is allowed to go back and enter the missing information.

If F10 is pressed before the Congressional District Number is entered, a box pops up and asks whether to (A)ccept, (M)odify or (E)xit. Exit will stop and not save the current data. Modify will allow editing of the current data, and/or additional data to be entered. Accept will record the current entry and return to the previous menu.

\section{Editing/Deleting a Project}

\section{To Edit a Project}

- $\quad$ Select Add/Edit Project \& Structure Inventory, option 1, from the Main Menu.

- Select Edit/Delete Project Information, option 2, from the Project/Structure/Reach Menu. 
The Select a Project to Edit screen will appear.

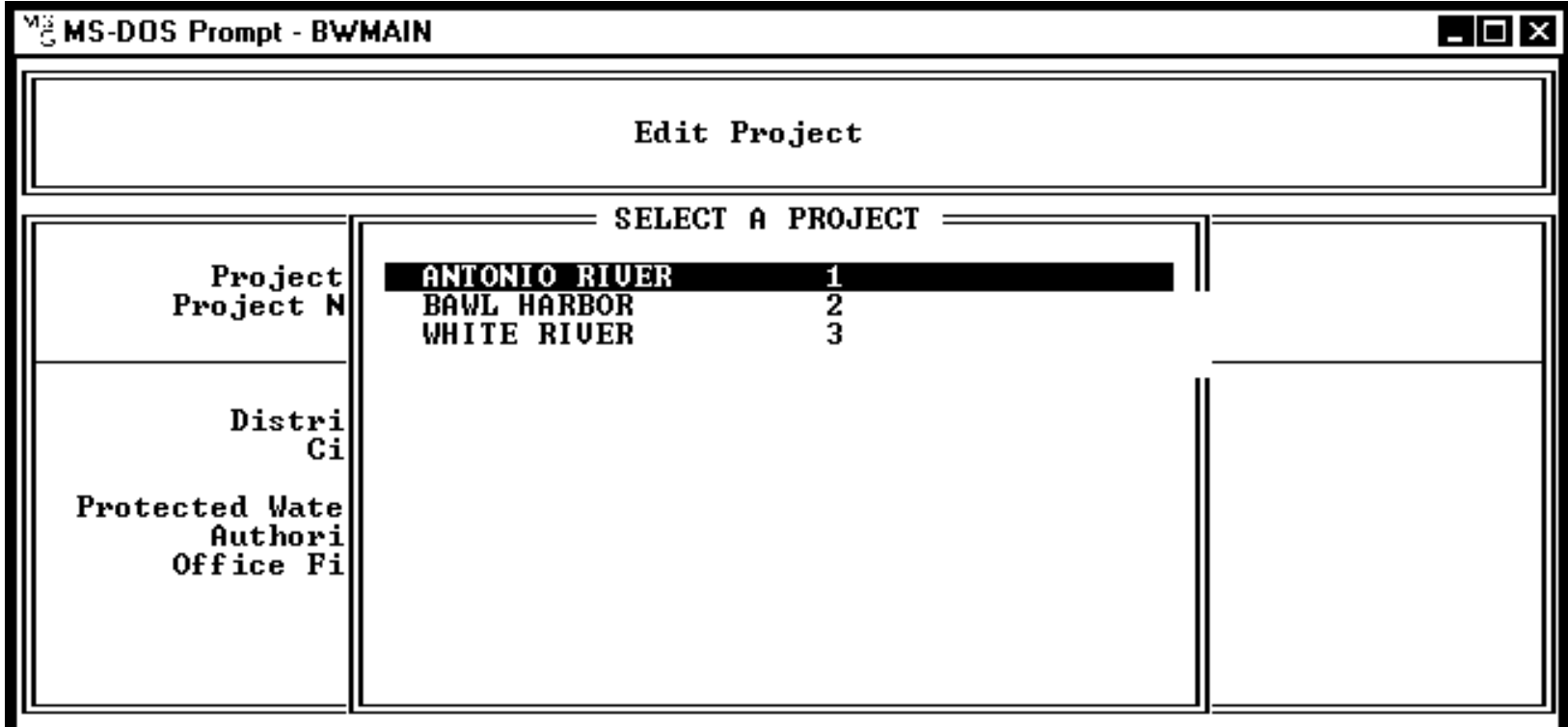

F1 Help F2 Del F3 Rest

F10 Done

After a short pause, a large bounce-bar menu appears within a box labeled Select a Project. Inside the box is the list of projects that have been defined. The project in the top row is highlighted. The arrow keys will move the highlight bar up or down as desired.

The list can be longer than that shown on the screen. The page down (PGDN) and page up (PGUP) keys may be used to flip to the next (or previous) screen.

Press [ENTER] to select the highlighted record for editing. At this point the user is ready to edit a previously defined project. The data entry screen will appear with the previously entered data next to the field names. The user may now step through each field in the same manner as when originally entered.

One exception is at the last field, Congress. The [ENTER] key will complete this entry and prompt the user with a small box to Save Record (Y/N)? After answering appropriately, the screen stays in the edit mode. F10 can also be used to indicate that the user is done editing the screen. When F10 is pressed the user will get an Accept, Modify, or Exit pop-up box. If no changes were made to the project record, the user will be returned to the previous menu after hitting F10. 


\section{To Delete a Project}

From the Select a Project to Edit box, pressing F2 for a highlighted project will mark that project for deletion. After pressing F2, the user is asked to confirm the deletion, by answering the prompt:

$$
\langle<\mathrm{No}\rangle>\quad\langle\text { Yes }>
$$

By pressing $\mathbf{Y}$ the user confirms the removal of the project data. The $\mathbf{N}$ key will abort the command and not delete the data. The user will be returned to the Select a Project box and can proceed to mark other records for deletion.

The user should note that records marked for deletion are denoted with a "D" to the left of the Project Name. Pressing F3 while the highlight bar is on a marked record will restore the record from deletion. The user is asked to confirm the restore with a $\langle<\mathbf{N o}\rangle\rangle\langle$ Yes $\rangle$ prompt. Records can be marked and unmarked for deletion as often as desired before the F10 key is pressed.

The F10 key is used to signal that the user is done and the message "packing ...." appears briefly on the screen. The program returns to the previous menu.

NOTE: When records are marked for deletion, if the user attempts to edit a record by pressing the [ENTER] key the records will be permanently deleted, just as though F10 had been pressed.

\section{Defining a Structure}

\section{To add (define) a structure}

- Select Add/Edit Project \& Structure Inventory, option 1, from the Main Menu.

The screen that appears is the Project/Structure/Reach Menu, shown under the Defining a Project section earlier in this chapter.

- $\quad$ Select Add Structure Information, option 3, from the Project/Structure/Reach Menu.

The Select a Project screen will appear enabling the user to select a project under which to add a structure. 


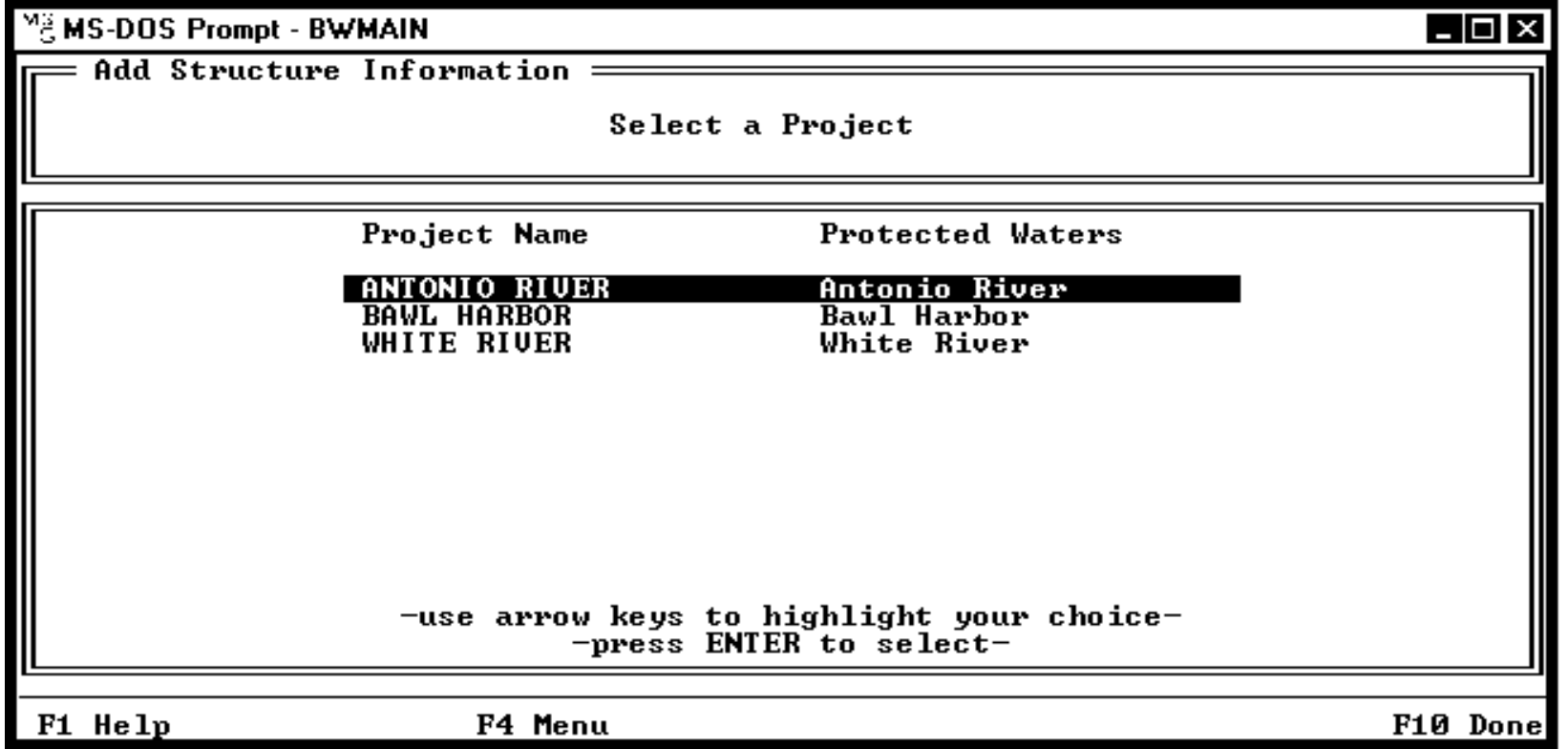

Use the arrow keys to highlight a Coastal Project.

- $\quad$ Press [ENTER] to select a project.

(Note: If the user decides not to add a project at this time, pressing $\mathbf{F 4}$ will return to the previous menu).

The Add Structure data entry screen will then appear. The following data should be entered for each structure:

Structure Name: The name corresponding to the structure.

Total Length: The total length of the structure to the nearest foot.

Structure Intent: The purpose of the structure.

Year Completed: The year that the structure was completed and fully operational.

Structure Type: Pick one: Breakwater or Jetty.

Connection Type: Pick one: Shore-connected or Offshore.

Structural Elevs.: Pick one: Overtopping or Nonovertopping.

Armor - Crest: $\quad$ The type of material of which the crest / cap is composed.

Armor - Sea Side: The type of material of which the seaside slope of the structure is composed.

Armor - Channel/

Harbor Side: The type of material of which the channel/harbor side slope of the structure is composed.

Foundation: $\quad$ The type of material of which the foundation of the structure is composed.

Crest Width: The total width of the crest to the nearest foot.

Auxiliary: The auxiliary structures that exist on the structure. (i.e. navigation lights, hand railing, etc.) 
Head Reach: $\quad$ The designation or label to indicate which reach is a structure head. (an offshore breakwater typically will have two head reaches)

The structure type fields are each filled in with a pop-up menu that appears with the appropriate options available. To select, use the arrow keys to highlight the proper choice and press

[ENTER]. For the index calculations to be done properly, the system requires the following fields be filled in: Structure Name, Breakwater/Jetty, and Total Length.

NOTE: The Structure Name field must be completed. If left blank, a pop-up box will give a warning message, and the user is then returned to editing that structure.

- $\quad$ Press F10 when done entering structures. A pop-up box will then appear with the choices [A]ccept, [M]odify, or [E]xit. Choose Accept, or hit return on the last data field and all of your input will automatically be retained.

\section{Editing and Deleting a Structure}

\section{To Edit a Structure}

- Select Add/Edit Project \& Structure Inventory, option 1, from the Main Menu.

- Select Edit / Delete Structure Information, option 4, from the Project/Structure/Reach Menu.

- $\quad$ Select a project, same as when Adding a Structure.

A box will appear that lists the structures under the selected project. Use the arrow keys to highlight a structure and press [ENTER]. 


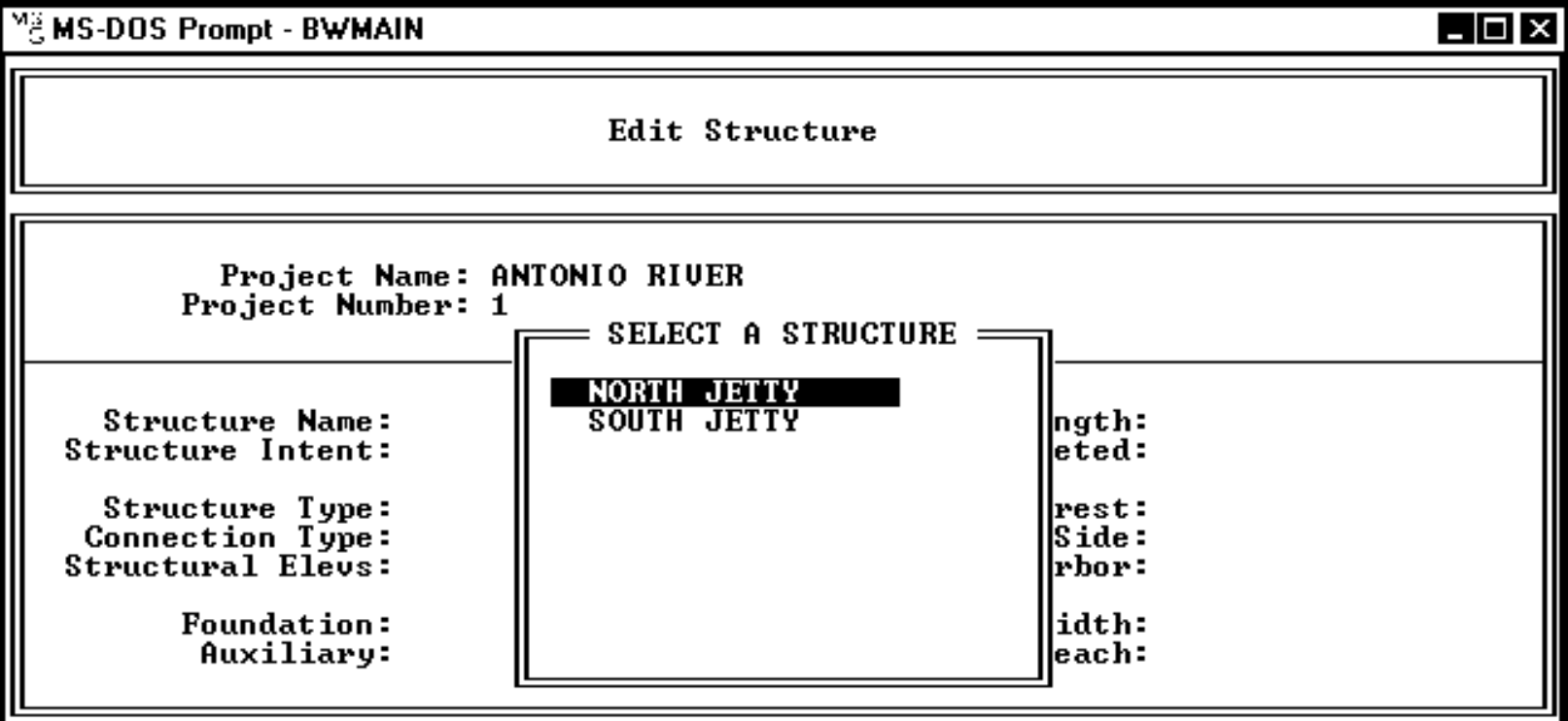

F1 Help F2 Del F3 Rest

- The system will then display the current data for editing.

- If F10 is pressed when the cursor is at any field on the screen after entering data, the user will be prompted to [A]ccept, [M]odify or [E]xit the record. Choose Accept. Entering data consists of pressing the [ENTER] key when completing a data field.

\section{To Delete a Structure}

Follow the same procedures as for editing a structure. At the Select a Structure box, use the F2 key to mark that structure for deletion. The deletion procedure works the same as when deleting a project. See the Deleting a Project section earlier in this chapter for more details.

\section{Defining a Reach}

\section{To Add a Reach}

- $\quad$ Select Add/Edit Project \& Structure Inventory, option 1, from the Main Menu.

- Select Add Reach, option 5, from the Project/Structure/Reach Menu.

As for adding a structure, the user must first select a project in which to add a reach. Use the arrow keys to highlight the project and press [ENTER] to select. After selecting a project, the user must select a structure under which to define a reach. The Select a Structure screen is very similar to the Select a Project screen. Use the arrow keys to highlight the desired structure and 
press [ENTER] to select. After selecting a structure the Add Reach screen is available for data entry.

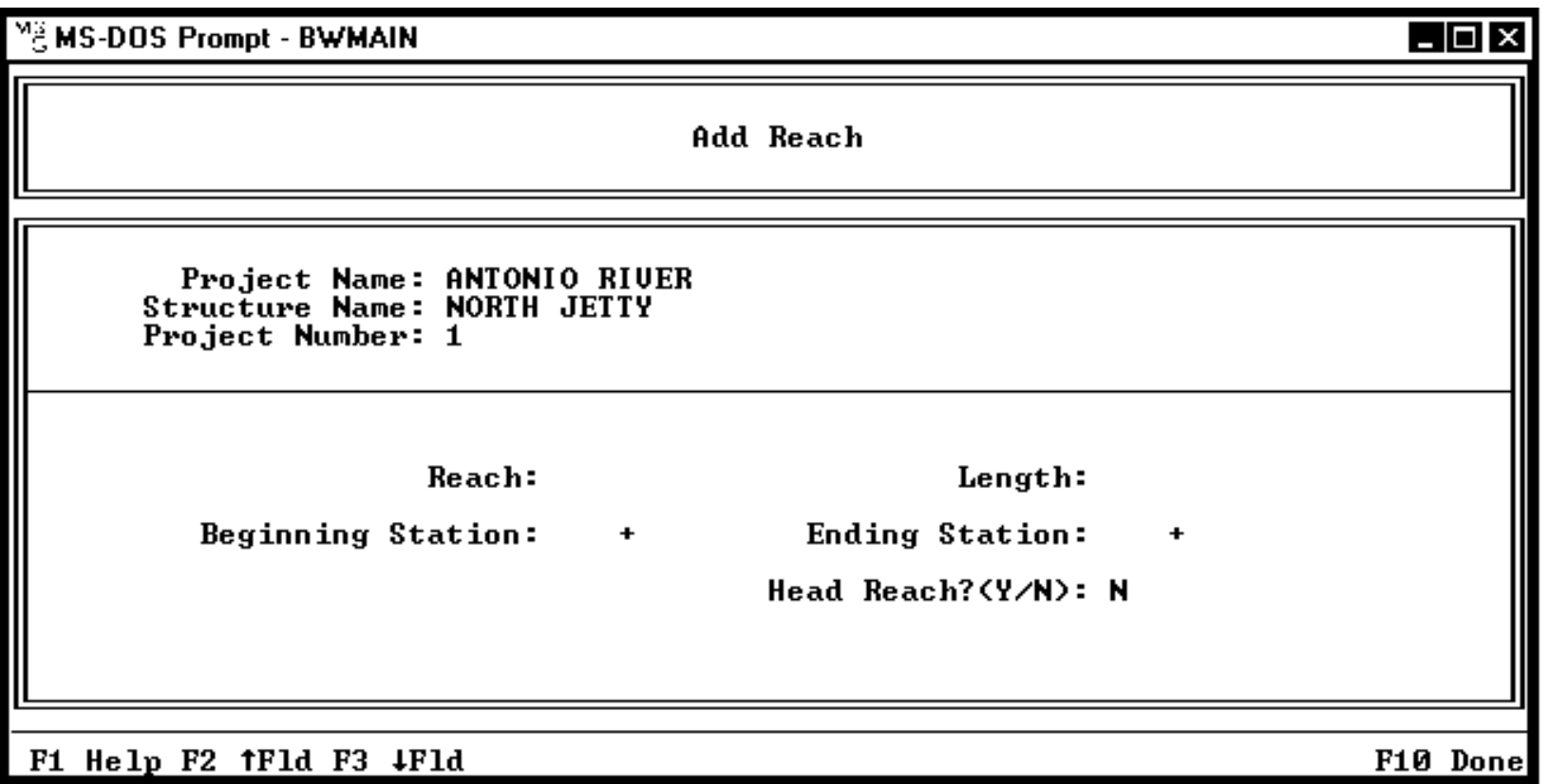

The following data should be entered for each reach:

Reach: $\quad$ The reach designation (reach number).

Length: The length of the reach in feet.

Beginning Station: The surveyor's station number at the start of the reach. (i.e. $25+04$ represents $2504 \mathrm{ft}$. - from the beginning of the structure).

Ending Station: The surveyor's station number at the end of the reach.

Head Reach?(Y/N): If the reach is a head reach, answer [Y] for yes, otherwise, [N]

After data entry for the reach is complete, the user is able to continue adding reaches under the selected project and structure.

- $\quad$ Press F10 when finished adding reaches. The program then returns to the Select a Structure screen which must be selected to add more reaches under a different structure. Press F10 to return to Selecting a Project. Press F10 one more time to return to the Project/Structure/Reach Menu. 


\section{Editing/Deleting a Reach}

\section{To Edit a Reach}

- $\quad$ Select Add/Edit Project \& Structure Inventory, option 1, from the Main Menu.

- Select Edit/Delete Reach, option 6, from the Project/Structure/Reach Menu.

As for adding a reach, the user must select a project and a structure. If no reaches have been defined for the selected project and structure, a pop-up box will appear and the user will be able to select another structure. A similar pop-up box will appear if no structures have been defined under the selected project. The user may then select another project.

After a project and a structure have been selected, the Select a Reach box will pop up, as shown in the sample screen below.

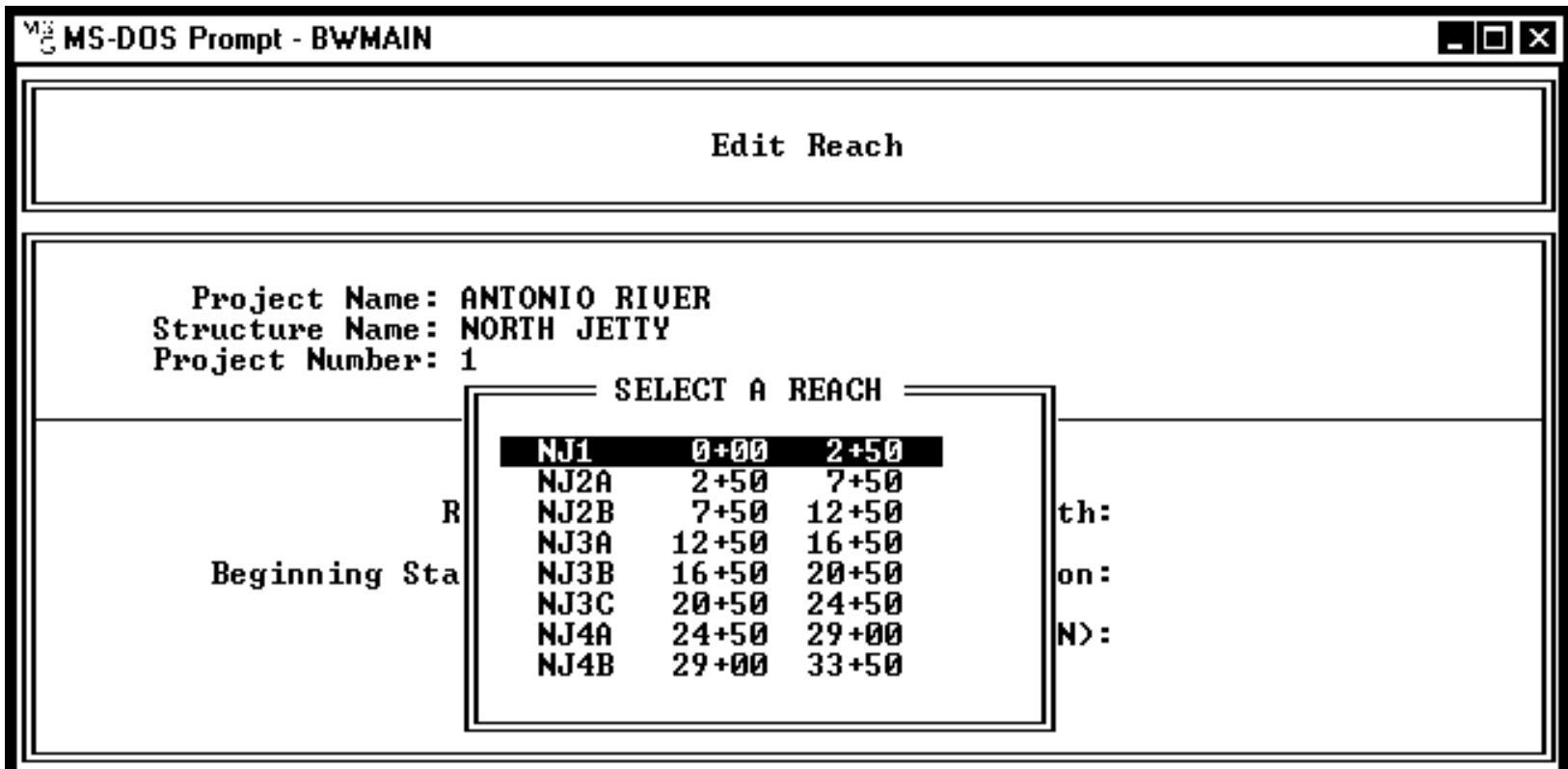

F1 Help F2 Del F3 Rest

Use the UP arrow and DOWN arrow to highlight the desired reach, then press [ENTER] to select. Reaches are listed by their name,and beginning and ending stations.

After selecting a reach, the user can edit the data that defines the reach by using the arrow keys and the F2 and F3 keys to navigate the screen. Pressing the UP arrow when on the first field will scroll to the previous reach, which can then be edited. Pressing the DOWN arrow when on the last field will scroll to the following reach, which can then be edited. 
If F10 is pressed when the cursor is at any field on the screen after entering data, the user will be prompted to [A]ccept, [M]odify or [E]xit the record. Choose Accept to save the edited data.

Entering data into the program occurs when the [ENTER] key is pressed after completing a data field. After saving the changes, the program returns the user to Project/Structure/Reach Menu.

\section{To Delete a Reach}

Follow the same path as for editing a reach, up to the Select a Reach box. At this point, the F2 key can be used to toggle to the choice for deleting a reach. For more details, see the Deleting a Project section in this chapter. 


\section{Inspection}

\section{Adding Inspection Data}

The process of adding Inspection Data begins at the Main Menu. Select option 3, Add Inspection Data, and a list of coastal projects is presented:

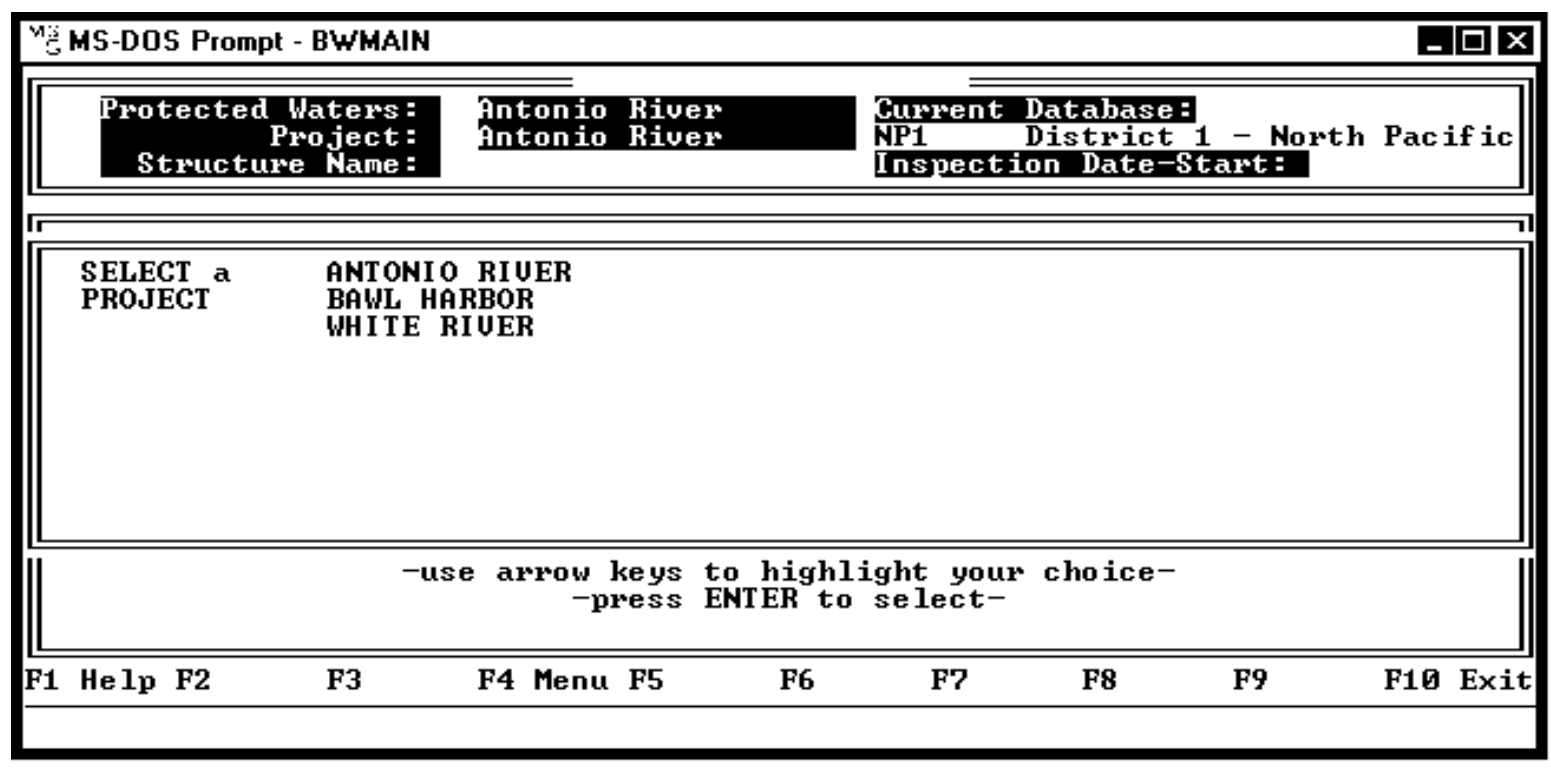

Using the arrow keys, highlight the project to be selected and press [ENTER]. The user will then be presented with the structures associated with that project:

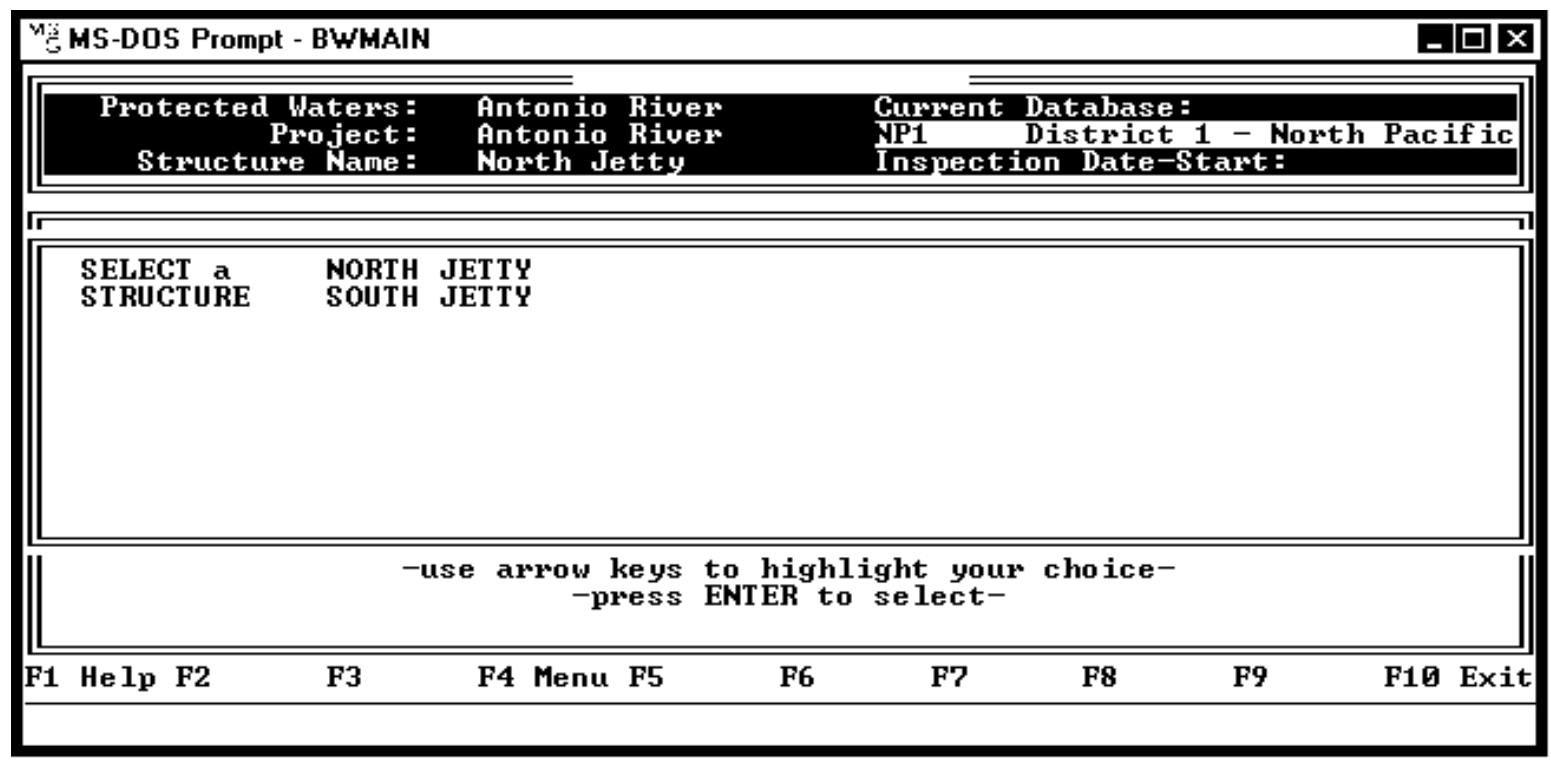


The list may be longer than what is shown on the screen. The page down (PGDN) and page up (PGUP) keys may be used to see the next (or previous) screen. Highlight the desired structure and press [ENTER]. The screen will then show dates for inspections that have been recorded for that structure:

\begin{tabular}{|c|c|}
\hline \multicolumn{2}{|l|}{ MS-DOS Prompt - BW/MAIN } \\
\hline $\begin{array}{r}\text { Protected Waters: } \\
\text { Project: } \\
\text { Structure Name: }\end{array}$ & $\begin{array}{ll}\text { Antonio River } & \text { Current Database: } \\
\text { Antonio River } & \text { NP1 } \\
\text { North Jetty } & \text { Inspection Date-Start: }\end{array}$ \\
\hline $\begin{array}{l}\text { SELECT an } \\
\text { INSPECT I ON DATE }\end{array}$ & $\begin{array}{l}\text { New Inspection Date }<-- \text { Create a New Inspection Date } \\
\text { o5 } / 27 / 1990 \\
\text { or select a date previously } \\
\text { entered. }\end{array}$ \\
\hline F1 Help F2 & F4 Menu F5 \\
\hline
\end{tabular}

With the arrow keys, the user may select one of the dates shown or enter a new inspection date by selecting New Inspection Date.

NOTE: It is important for the user to enter the Inspection Start Date by structure and not by each individual reach. Use the date that the first reach was inspected as the date for inspection of all reaches within the structure, even if inspection of some reaches was not actually completed (or started) that day. Inspection data for the reaches will not be associated with a complete inspection of the structure if different dates are entered for each reach.

After the date is entered, a pop-up screen (as on the next page) gives the user the list of reaches within that structure. The user may scroll with the scroll keys to select a reach. The reaches were defined in option 1 (Add/Edit Project \& Structure Inventory) in the Main Menu. Note: Reaches must be defined before any inspection data for them can be entered. 


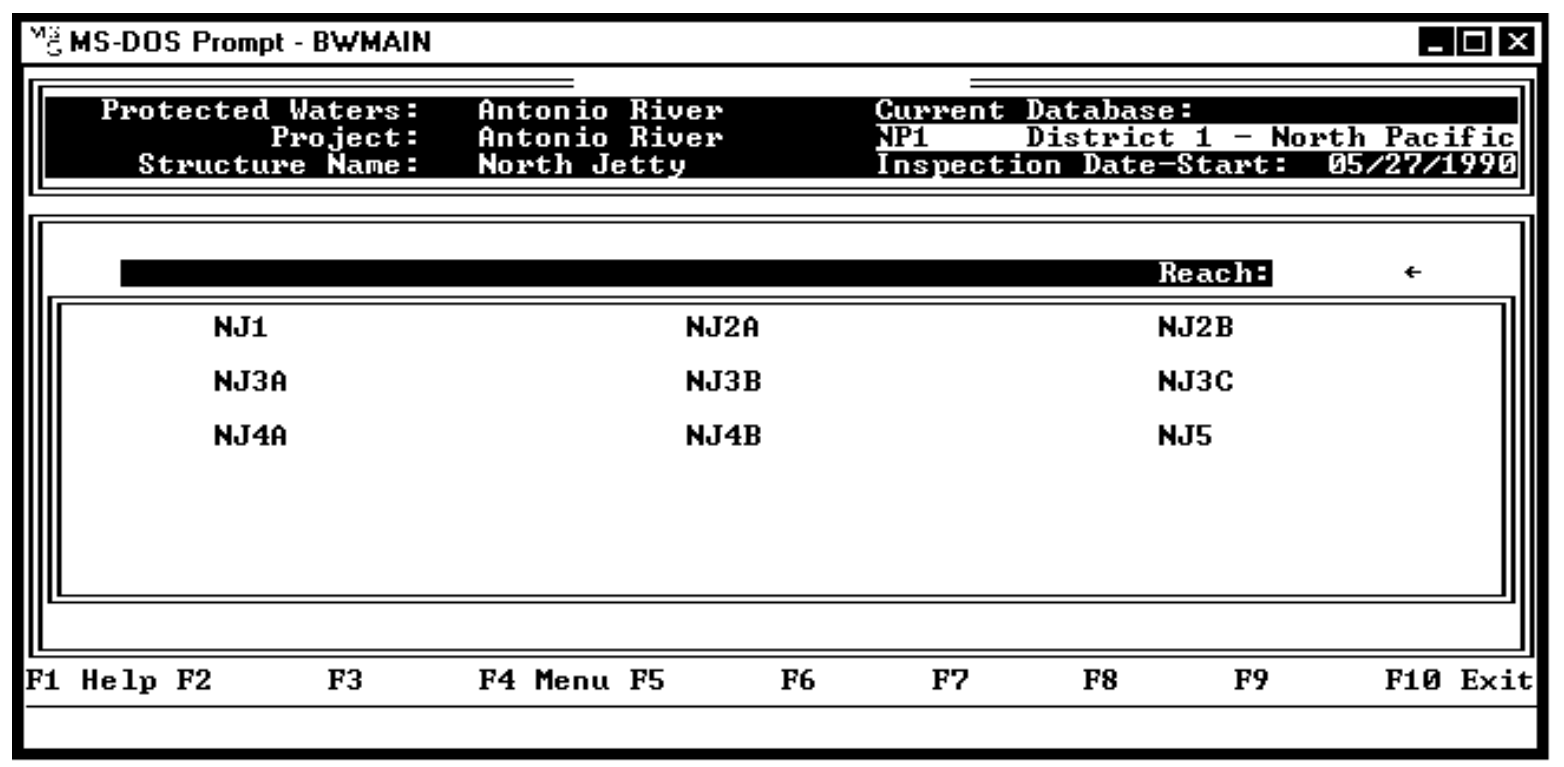

Inspection Date- Current and Inspection Time are entered next. This is the date and time that the selected reach is inspected. If data already exists for this date and structure, a message is displayed, offering the user an opportunity to modify the existing data:

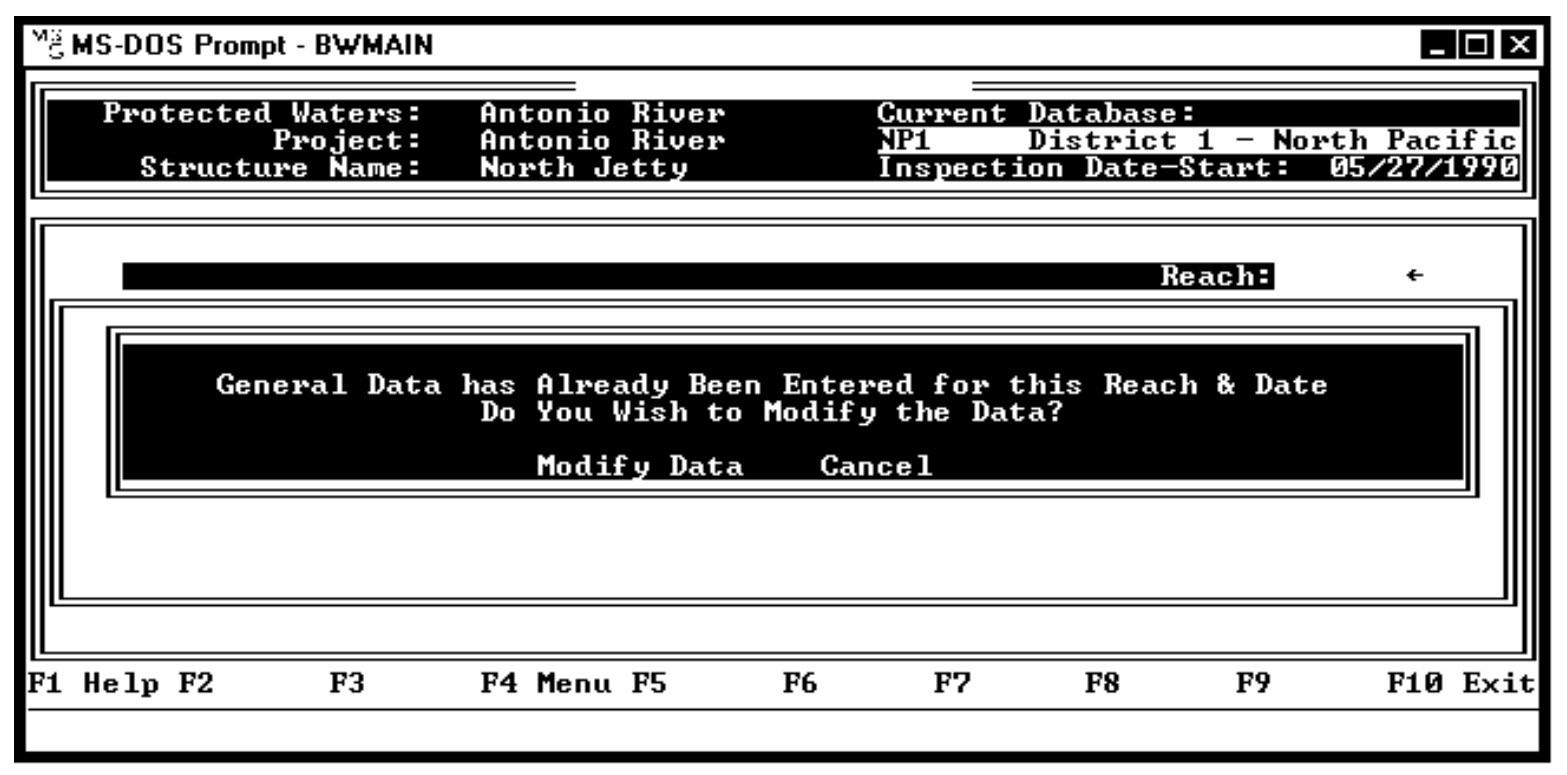


When the Date and Time are completed, the Inspection Team Data pop-up box is displayed. The team is a listing of the Inspectors, Addresses, and Office Symbols:

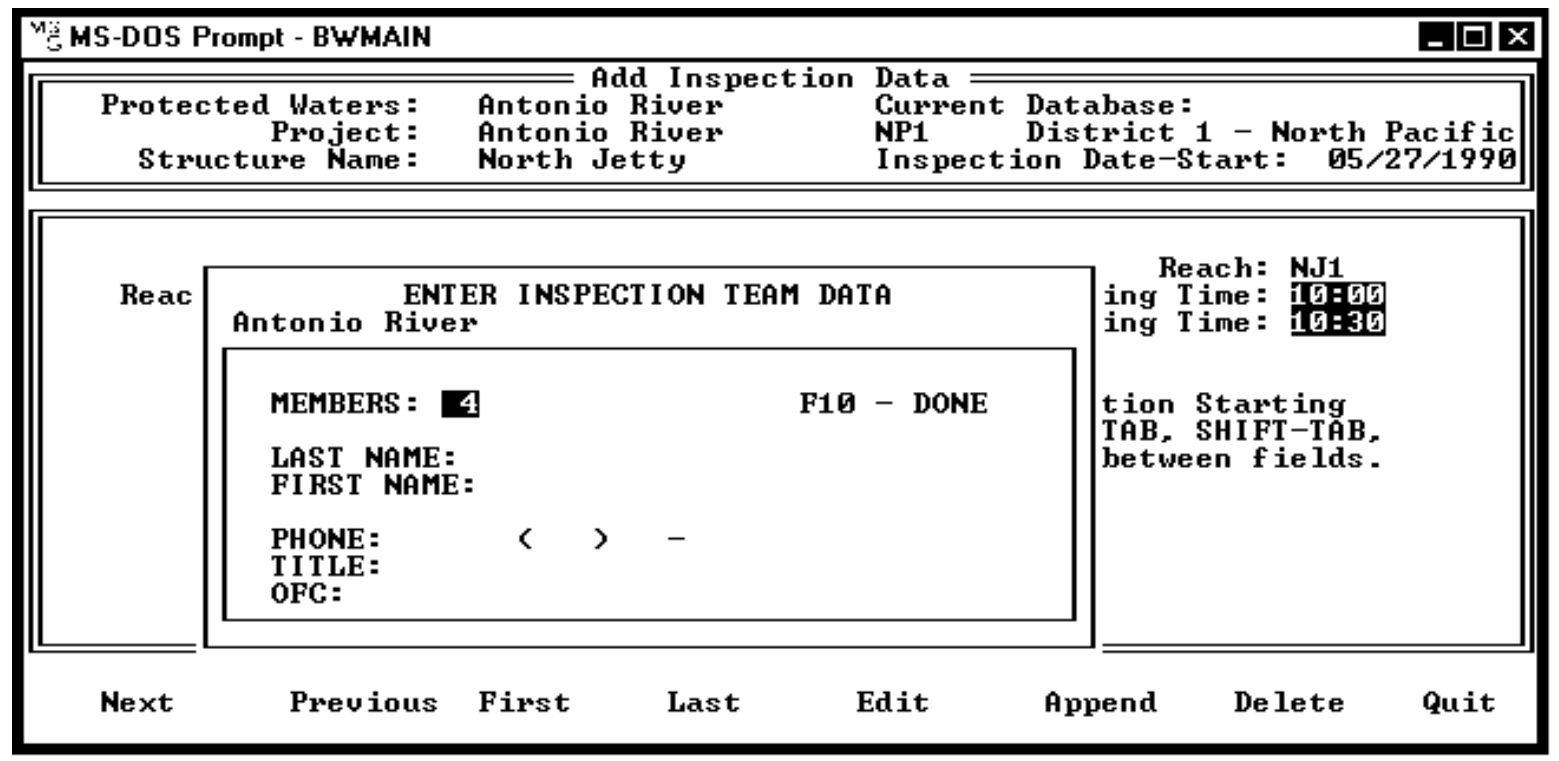

The menu at the bottom of the screen provides the capability to see additional Team Data that may exist for the structure. Highlight the NEXT, PREVIOUS, FIRST and LAST options to view the various records. To EDIT, APPEND and DELETE data, highlight the appropriate option and press [ENTER].

After the Inspection Team Data is completed, choose $\mathbf{Q}$ for Quit. The next screen allows you to input the Sea and Weather Conditions on the day of the Inspection for the selected reach. Highlight the appropriate condition and press [ENTER], or input the appropriate values using the keyboard:

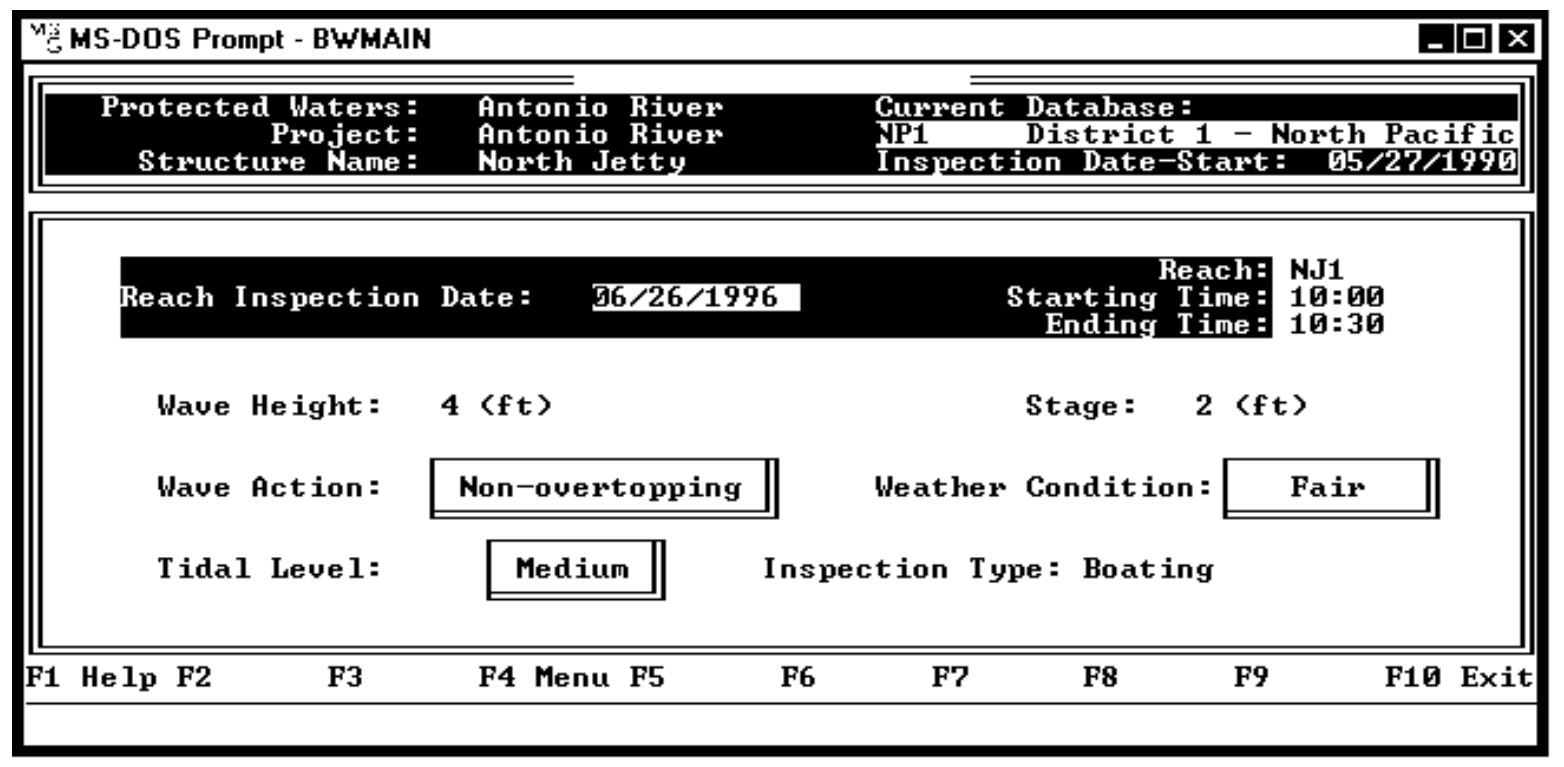


The Inspection Type field must be typed in by the user. These inspection types may include, but are not limited to, walking and boating.

\section{Modifying Inspection Data}

To begin the process of modifying inspection data, select Modify/View/Delete Inspection Data option 2, from the Main Menu. The following are selected from scrolling menus in this order:

- $\quad$ Project

- $\quad$ Structure

- Inspection Date

- Reach

After entering this data, the Select Data to Enter menu is presented. This will be discussed in the MODES Section.

\section{Modes}

Upon completion of adding or modifying inspection data, the Select Data to Enter menu is displayed:

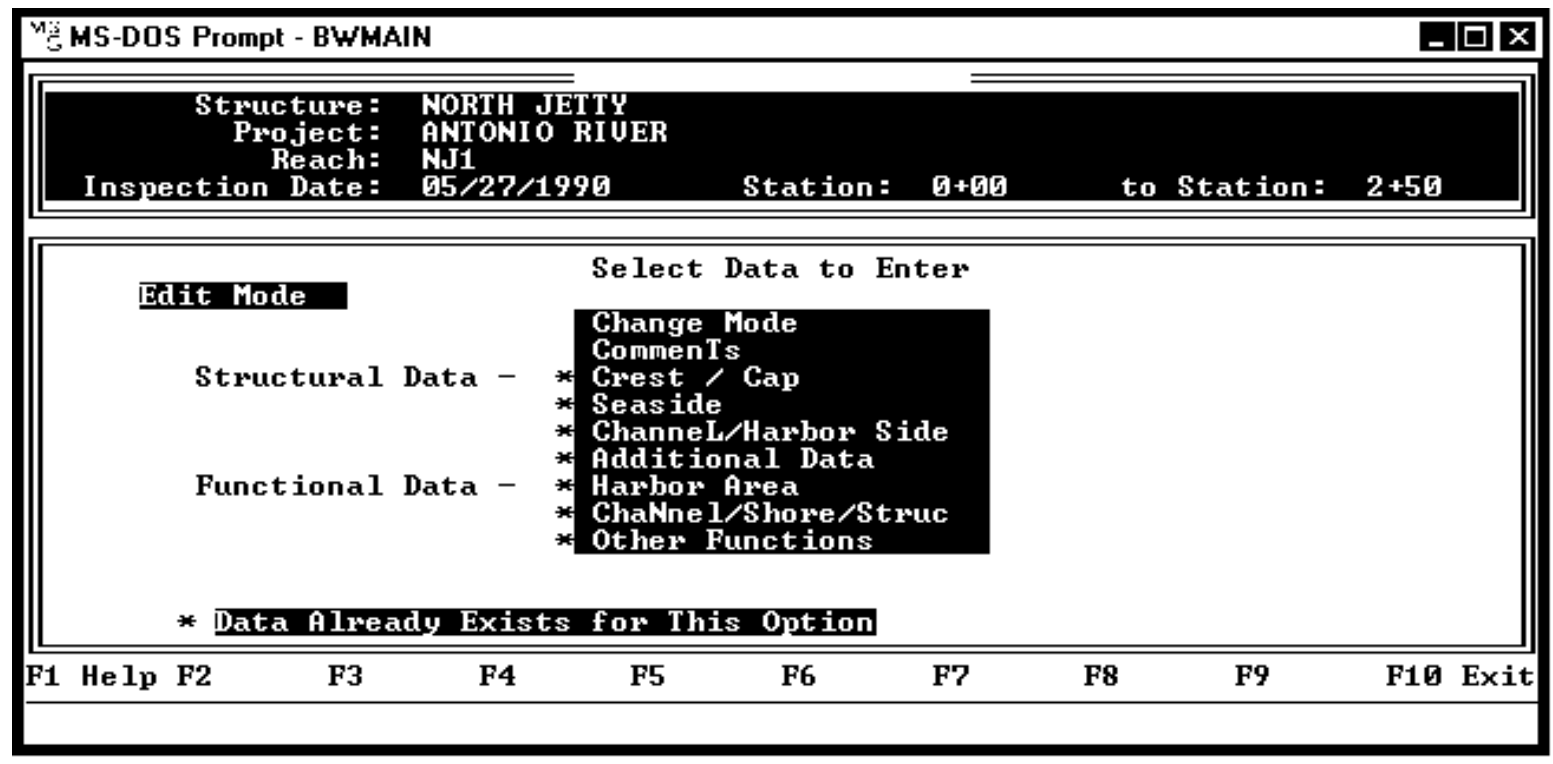




\section{Change Modes}

The manner in which the data is acted upon is executed through the Change Modes command. To activate this command, highlight Change Mode or press the trigger "M". Control is passed to the horizontal menu at the bottom of the screen. Add Data, Edit Data, Delete Data, and View Data are the selections. These choices have the following functions:

1. Add Data The information the user enters is added to the database.

2. Edit Data The information is retrieved from the database for the user to modify.

3. Delete Data All the information is erased from the database.

4. View Data The information is retrieved from the database for the user to view (but not change).

\section{Comments}

The feature, Comments, which is found in the Select Data to Enter menu, allows the user to make general comments about a reach. A document of overall comments for a specific reach can be created and edited. After selecting Comments from the Select Data to Enter menu, a box will appear titled COMMENTS. The user must press F8 to close the comment box. The comment box is displayed below.

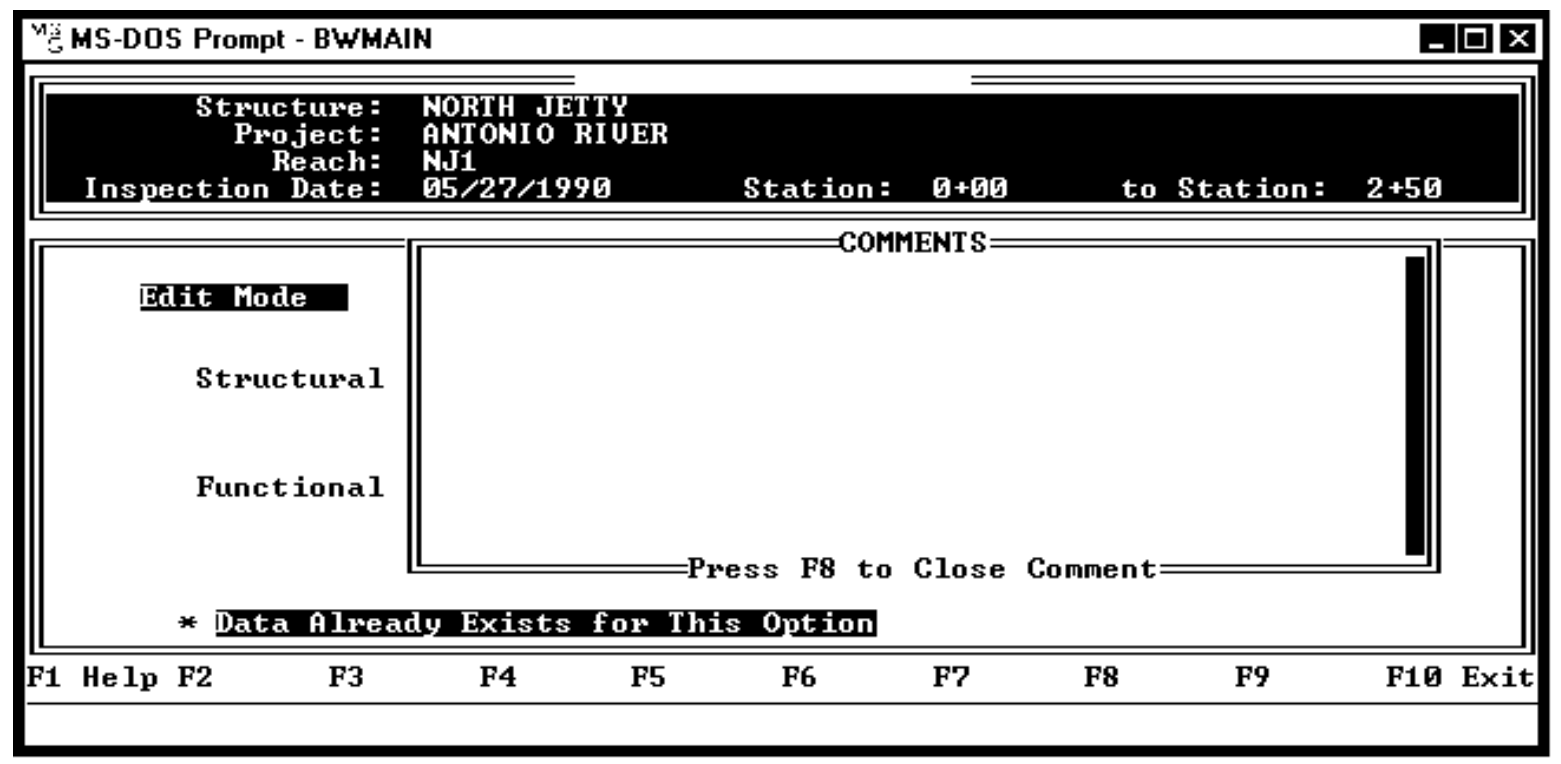




\section{Structural Data}

\section{Crest/Cap, Seaside (or Head) and Channel/Harborside Selections}

Each section, Crest/Cap, Seaside and Channel/Harborside, potentially can display the following types of distress:

Breach (for Crest/Cap only)

Core (or Underlayer) Exposure or Loss

Armor Loss

Loss of Armor Contact or Interlock

Armor Quality Defects

Slope Defects (Not Used for Crest/Cap)

Each distress type (rating category) is further defined by:

Recommended Action

Defect Type (for 4 of the 6 categories)

Reach Stations

CI Rating

The first entry is the rating (range: 0-100) for each structural rating category. Since breach only applies to the Crest/Cap area of the reach, it is dimmed (not available for data entry) in the Seaside and Channel/Harborside screens. Likewise, a slope defect applies only to the Seaside and Channel/Harborside slopes of the reach, therefore, it is dimmed (and not available for data entry) in the Crest/Cap screen.

Upon entering the Defect type field a pop-up menu appears with the available choices for 4 of the 6 rating categories. These four menus are described below.

Breach: The defect type pop-up menu for the breach is titled Breach Damage, and has four choices: a blank, None, Displaced, and Settling. (See example on next page).

Armor Loss: The defect type pop-up menu for armor loss is titled Armor Loss, and has 5 choices: a blank, None, Displaced, Settling, and Bridging. (See example on next page). 

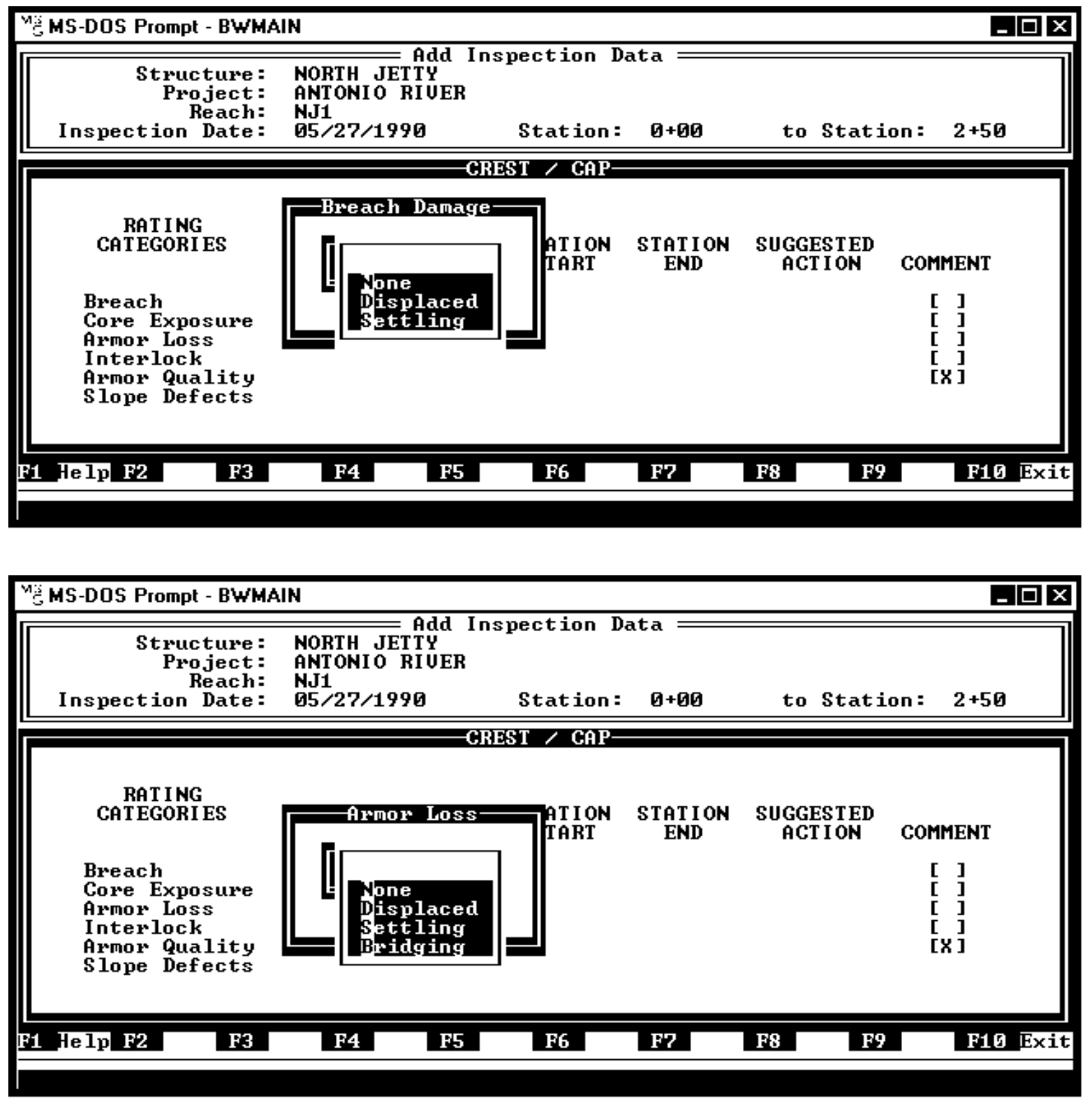

Armor Quality: The defect type pop-up menu for armor quality is titled Armor Quality, and has six choices: a blank, None, Rounding, Cracking, Spalling, and Fracturing: 


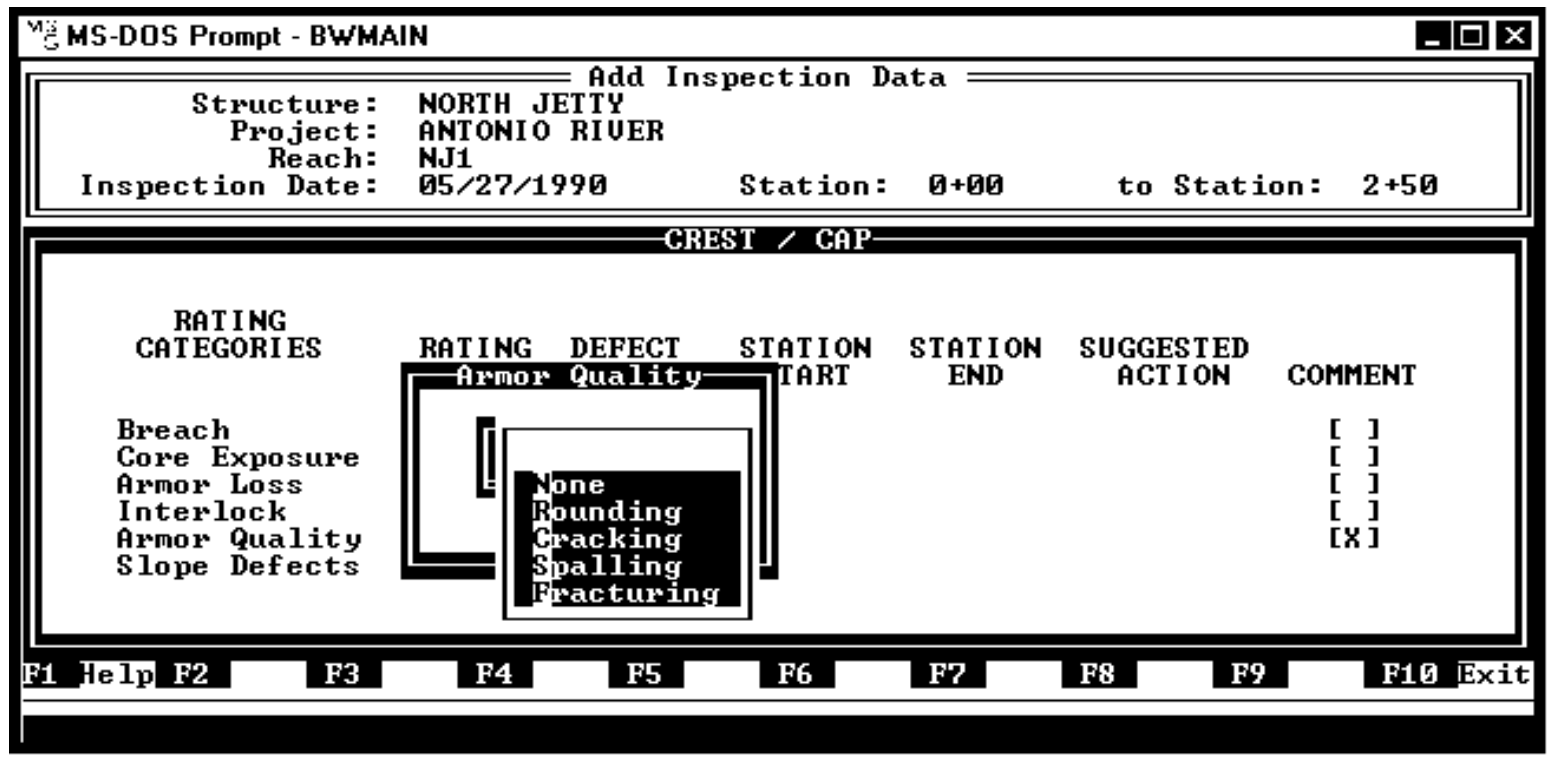

Slope Defects: The defect type pop-up menu for slope defects is titled Slope Defects, and has 4 choices: a blank, None, Steepening, and Sliding:

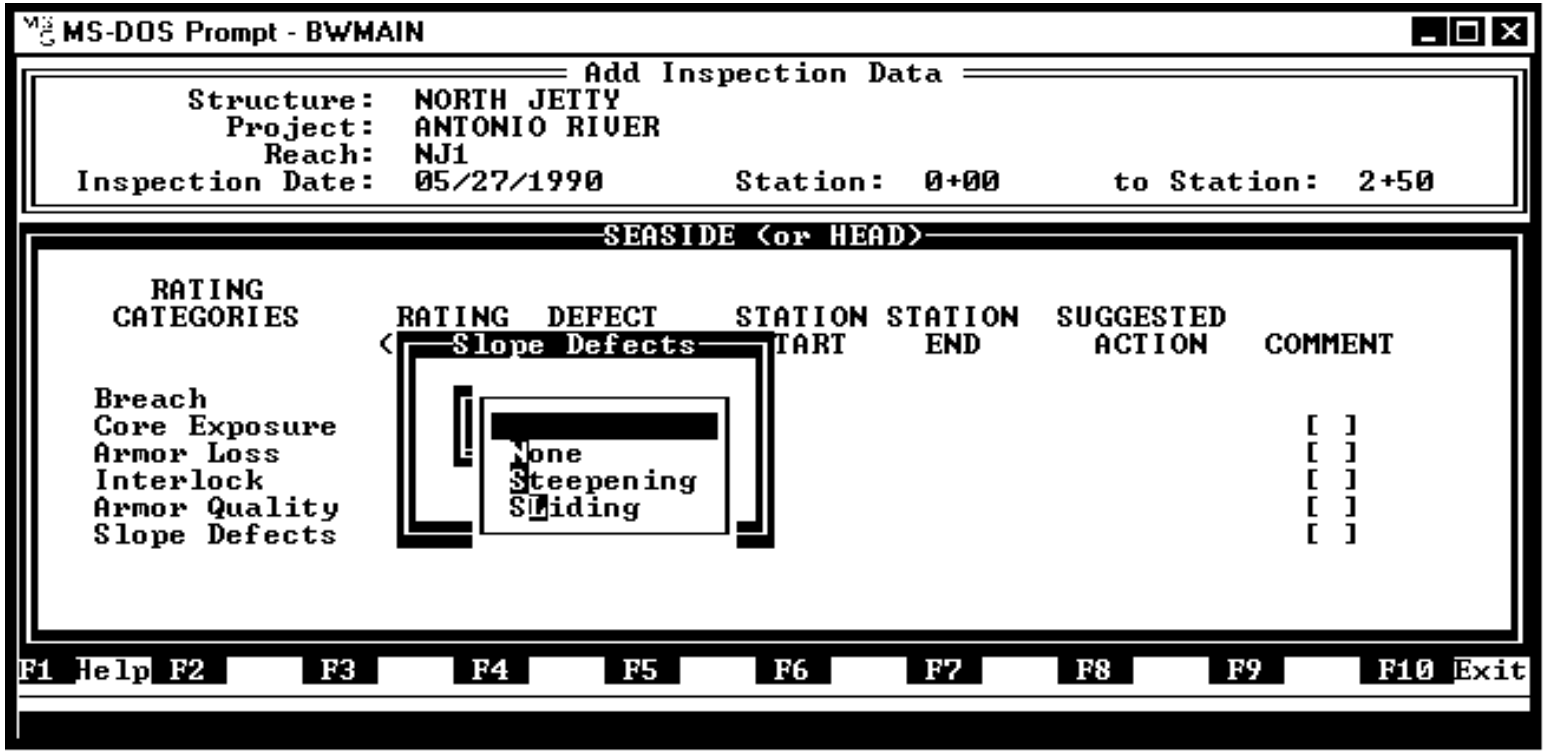

\section{Reach Stations, Suggested Actions, Comments}

After completing the defect ratings, the (surveyor's) stationing representing the beginning (Station Start) and ending points (Station End) of the observed defects are filled in. Next, are the Suggested Actions, as explained in the Procedures Manual, and in the right column, a place to mark that a comment is associated with the defect rating. A separate box is then made available in which to write the comments. 


\section{Additional Data}

Selecting Additional Data from the Select Data to Enter menu leads to another data entry screen (shown below). There are four comment categories on this screen: Warning Signs/ Gates, Auxilary Structures, Amount of Debris in Armor, and Below Water Indications. These are explained in the Procedures Manual. The last field, Below Water Indications, has a pop-up menu with the following 5 choices: a blank, Armor Dispacement, Slope Steepening, Slope Sliding, and None Visible.

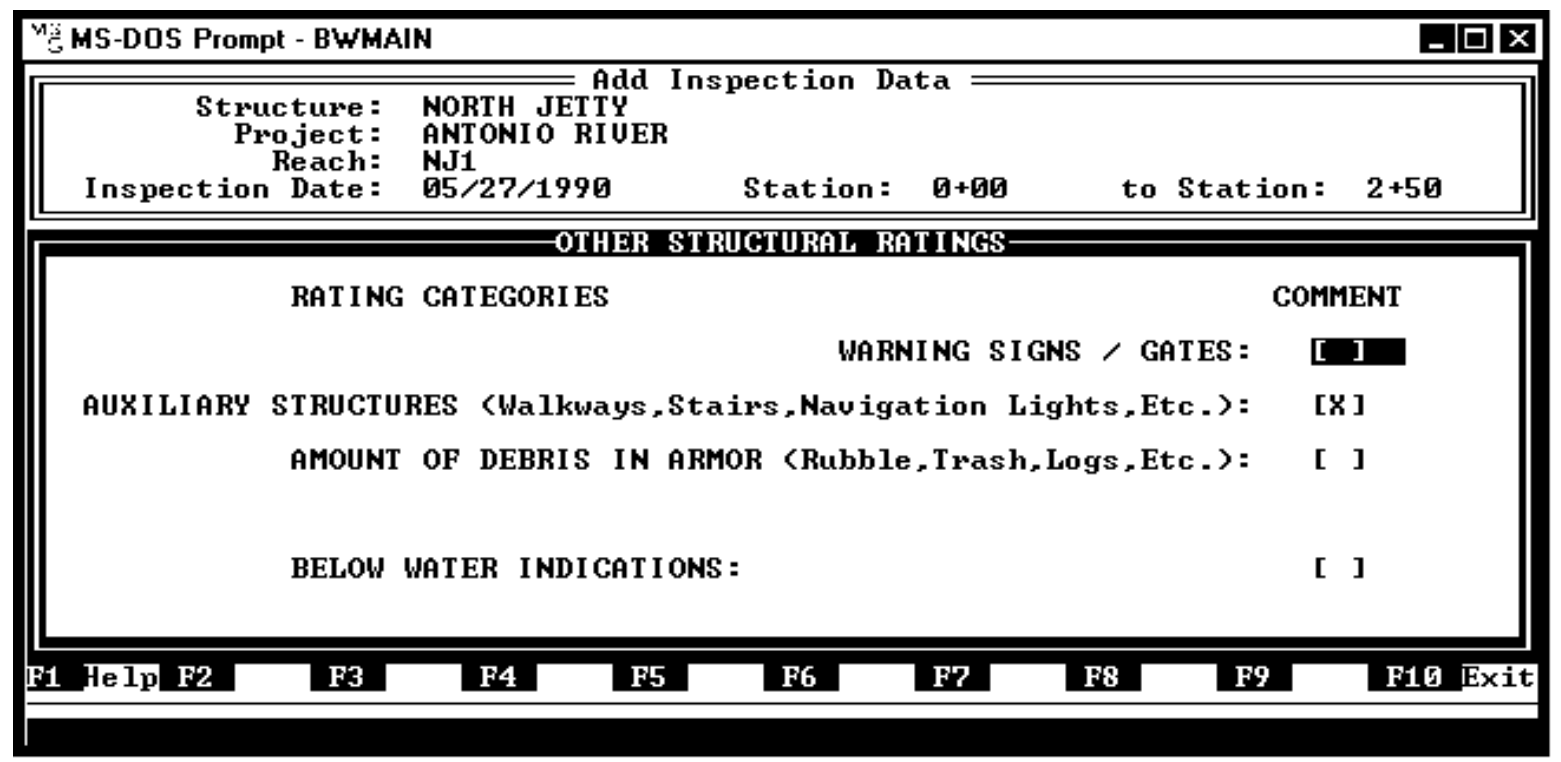

\section{Functional Data}

There are three screens for entering Functional Data: Harbor Area, Channel/Sediment/ Protection, and Other Functions. These match the general format found on the rating form, but are divided due to limited space available on a single screen.

For each category which applies to the reach being rated, enter the desired $0-100$ rating. If a rating category does not apply to that reach, (i.e. Ebb Shoal) then that category must be left blank. DO NOT USE ZERO. (Entering zero instead of leaving a category blank will result in incorrect index calculations).

The Recommended Action pop-up menu contains six choices: a blank, Immediate, Act Soon, Watch, Defer, and Investigate Further. These choices are explained in the Procedures Manual. Here is the Harbor Area screen: 


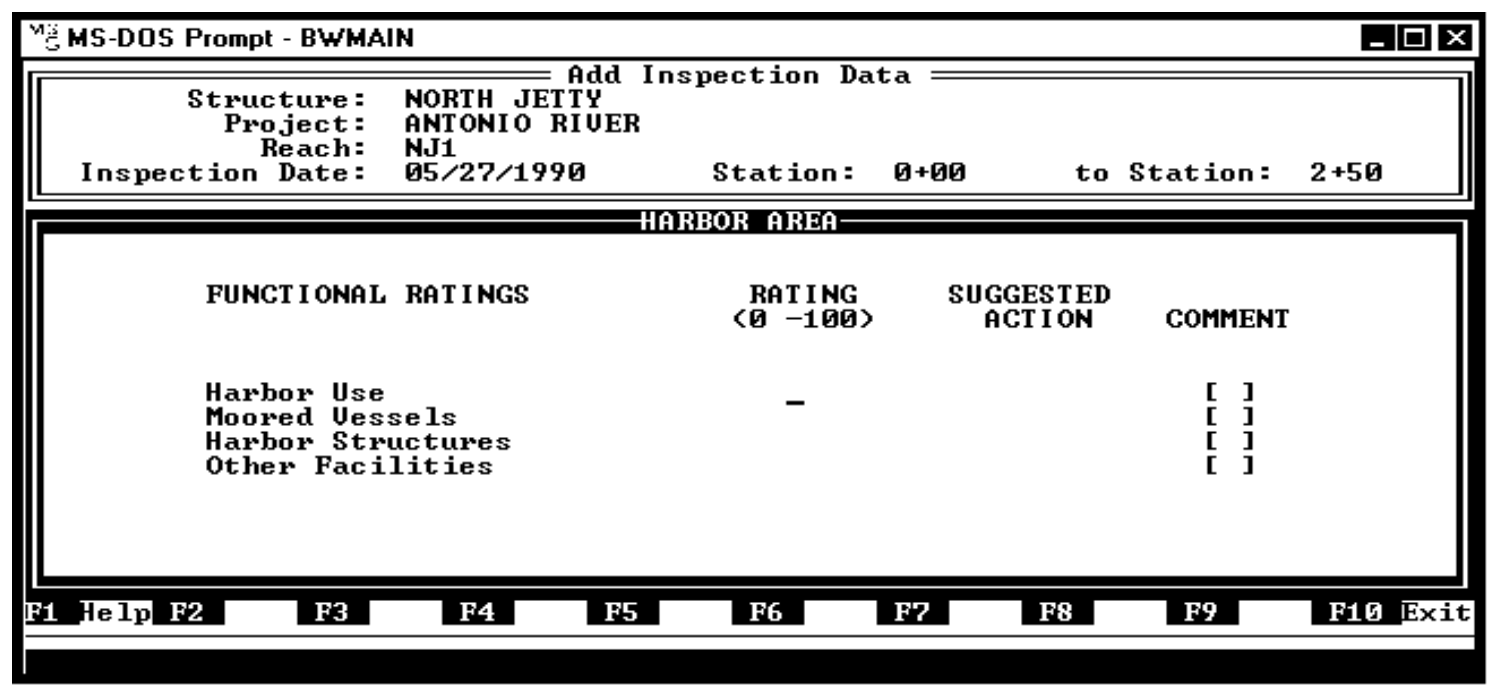

The Navigation Channel/Sediment/Protection screen contains three main functional areas, as shown in this example screen:

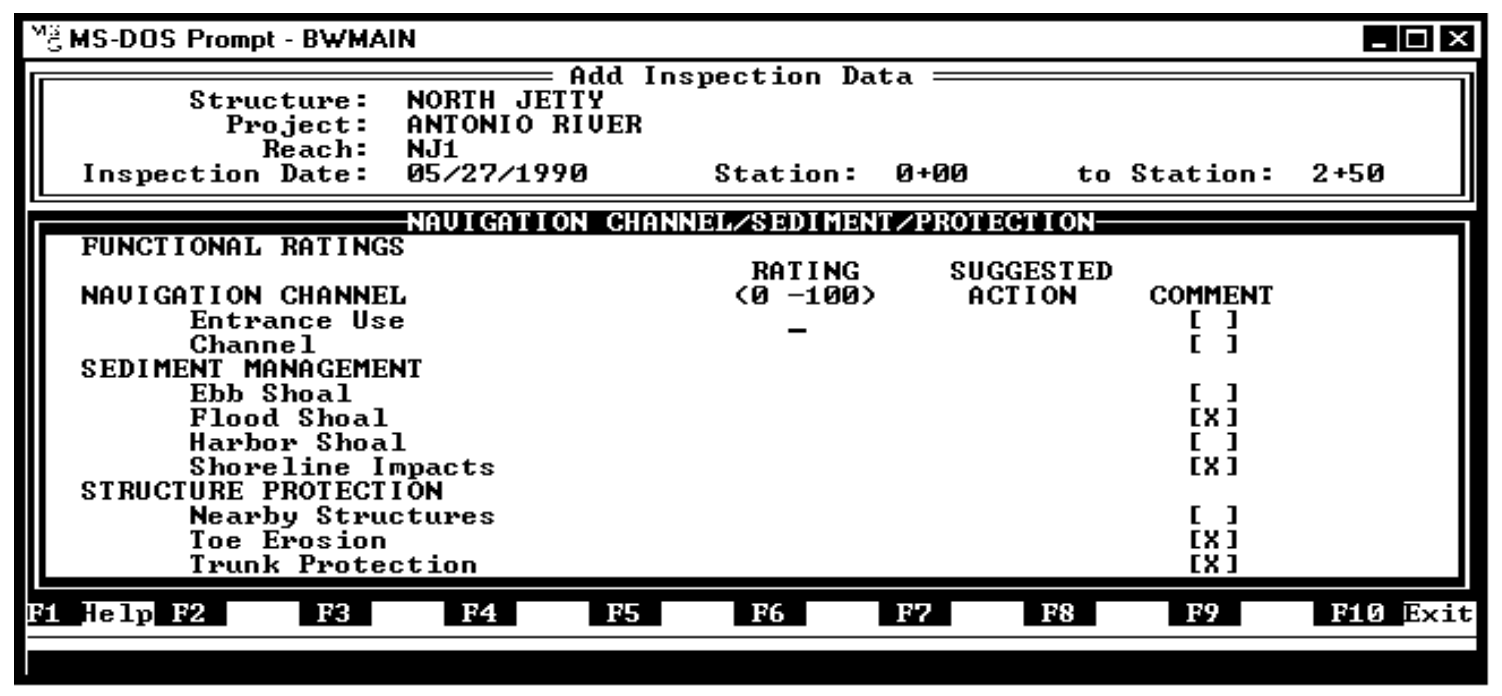

\section{Other Functions}

As described in the Procedures Manual, the four Other Functions do not take a rating, but rather a Suggested Action and Comment. Below Other Functions are the two questions which appear at the bottom of the rating form: 


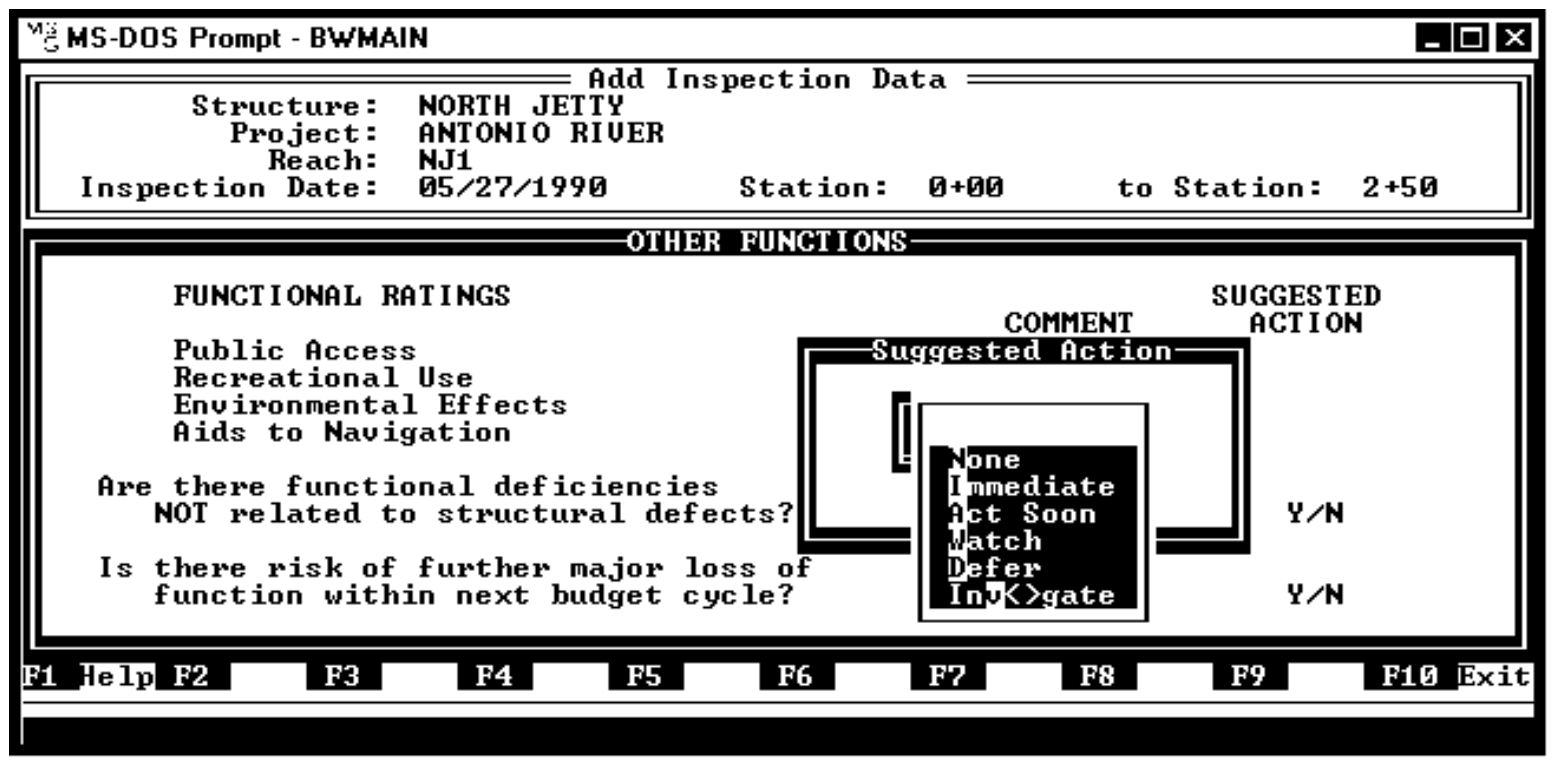




\section{Reports and Forms}

\section{General Organization and Operation}

Selecting Reports and Forms from the Main Menu will advance the user to another menu that contains a selection of reports. The items on this menu include:

[1] District Inventory Summary

[2] Condition Index Calc: Reach

[3] Historical Index Rating Summary

[4] Comment Report: Reach

[5] Missing Information Report

[6] Print Inspection Forms

[E] Exit - Return to Main Menu

After selecting a report type (from options 1-6 of the Main Menu), the user is given a series of pop-up menus that lead through the hierarchy of the choices. For example, for Condition Index Calc: Reach, a menu listing the projects appears first, then one listing the related structures.

Once a structure is chosen, a menu appears with inspection start-dates related to that structure. Finally, the fourth menu shows all the reaches related to that structure. Not all options react in this manner; however, this is the general format:

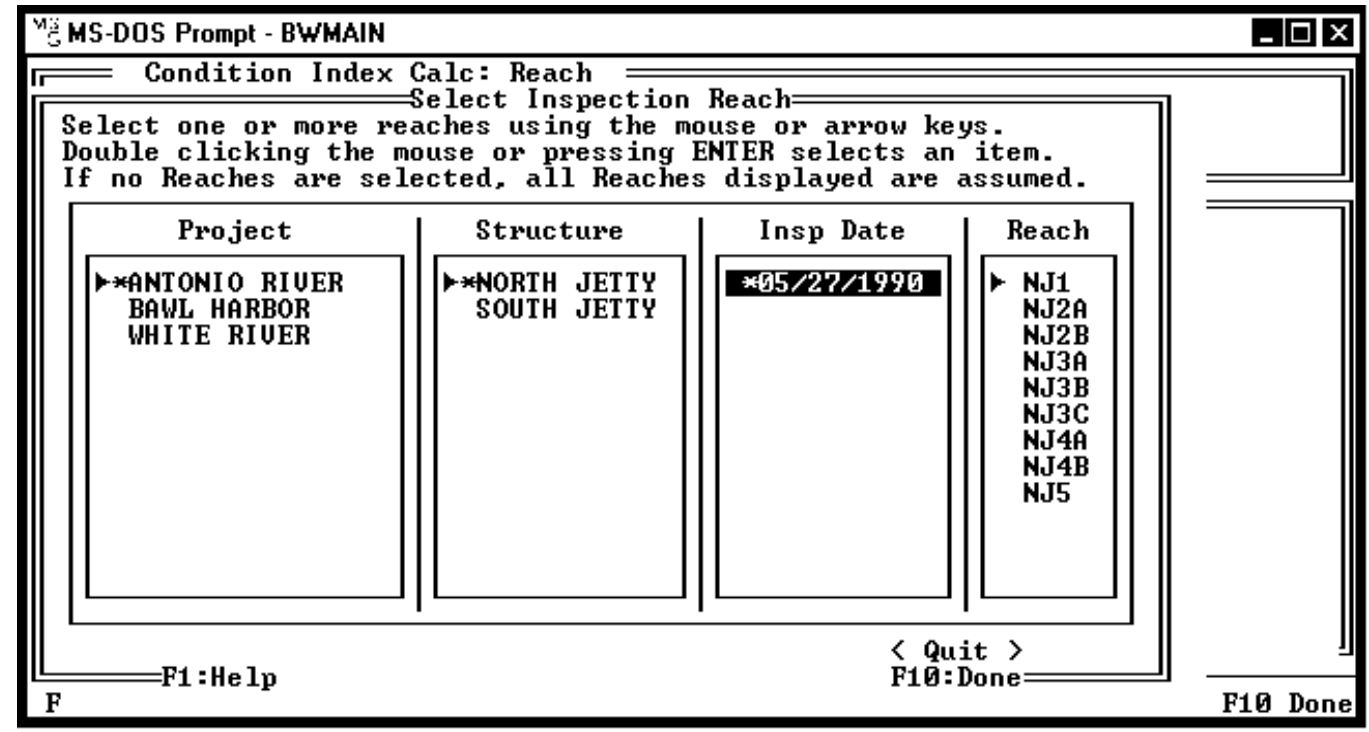

See Appendix A for examples of reports printed with different options. 
Two function keys are available on this screen: F1 for Help, and F10 for Done. Otherwise, follow directions on the screen for choosing the desired options.

For all report types, after Accepting the desired options for a report, hitting F10 will tell the program to prepare the report. The program will display the Output Options screen that provides the following choices: [T] Terminal, [P] Printer, [F] File, or [E] Exit.

- The Terminal option will display the report on the screen.

- The Printer option will send the report to a printer.

- $\quad$ The File option will prompt the user for a file name and will save the report on disk with the specified file name.

- $\quad$ Exit will bring back the main Report Menu screen.

\section{District Inventory Summary}

The District Inventory Summary screen (top of next page) gives the user a menu containing a selection of sort options for the reports. The sort options available include:

1. Project: Alpha Order (ASC)

2. Structural Index: (ASC)

3. Structural Index: (DESC)

4. Functional Index(CI): (ASC)

5. Functional Index (CI): (DESC)

6. Last Inspection Date: (ASC)

7. Last Inspection Data: (DESC)

\section{Condition Index Calc: Reach}

There are four menus involved in producing the Condition Index Calculation: Reach report, which appear in this order: Project Menu, Structure Menu, Inspection Start-Date Menu, and Reach Menu. (See next page for example screen).

The user may select one inspection start-date for a particular structure and obtain all of the inspection information for all of the reaches for that Inspection start-date. Otherwise, the user may pick one or more reaches for that structure for that particular inspection. In any case the report will include a summary of the structure's overall Structural Index, and Functional Index. 

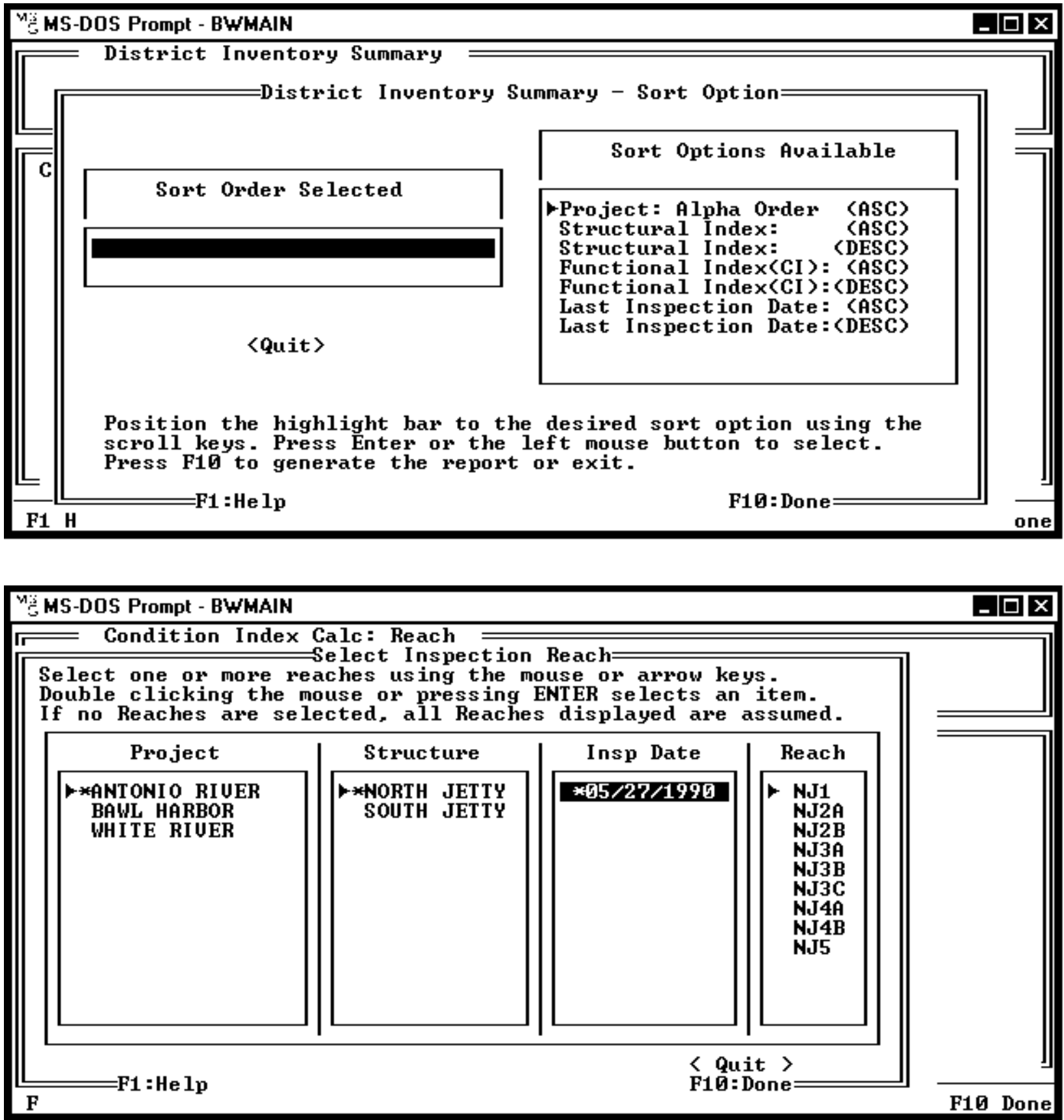

\section{Historical Rating Summary}

The Historical Index Rating Summary is a report based on a structure's inspection start-dates, structural index, and functional index. This report displays one project at a time. The user will see all of the structures within one project along with the structure's inspection start-dates, structural indexes, and functional indexes. There are two menus to obtain this report. They are Project Menu, and Structure Menu, as shown on the example screen below: 


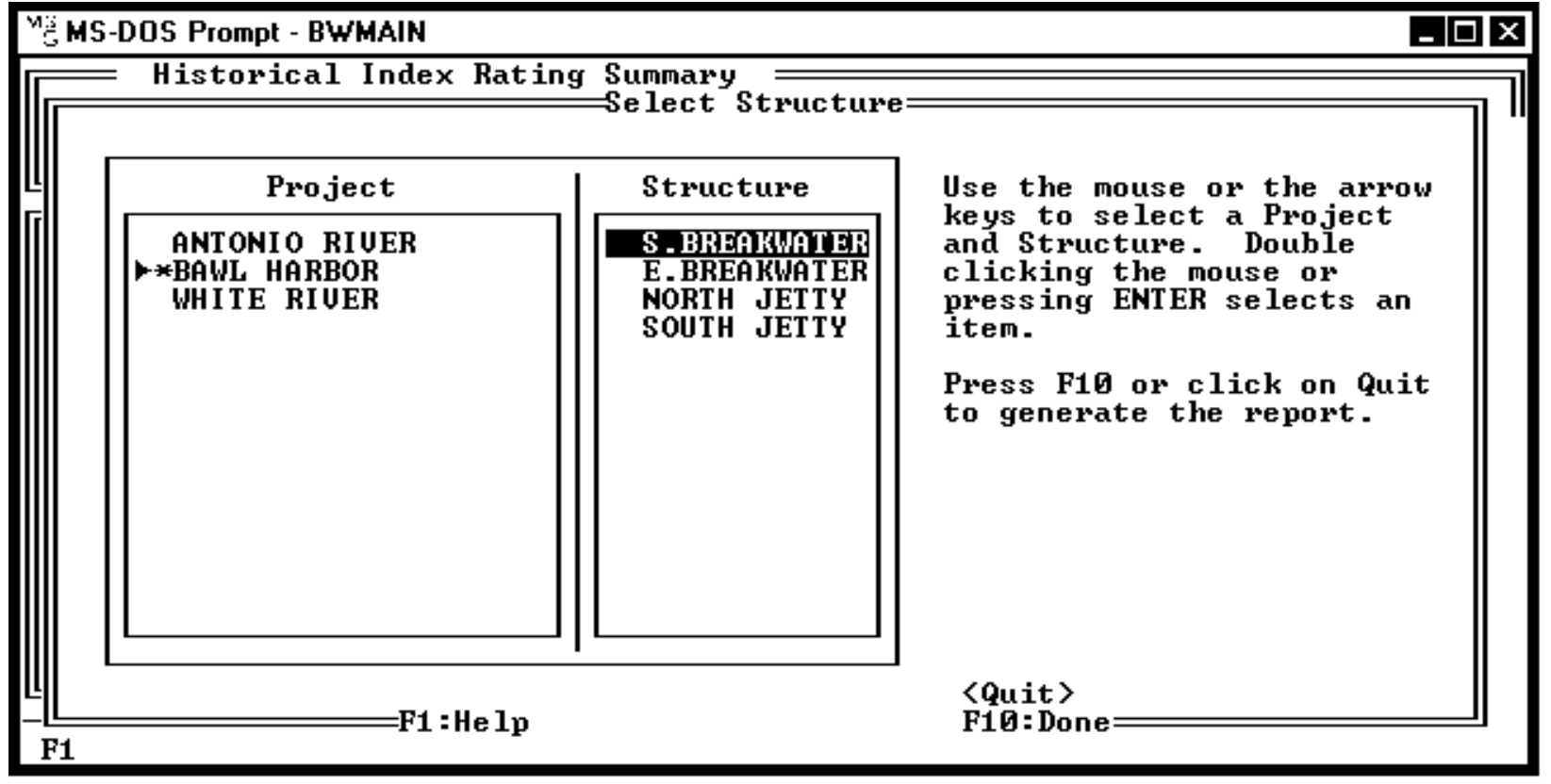

\section{Comment Report: Reach}

Obtaining a Comment Report: Reach is exactly like obtaining the Condition Index Calc:

Reach Report. The same four menus are presented: Project Menu, Structure Menu, Inspection

Start-Date Menu, and Reach Menu.

The user can choose to define the report with the same detail as in the Condition Index Calc:

Reach. The format is also similar to a field sheet; however, only the comments are listed in this report. An example screen is shown at the top of the next page. 


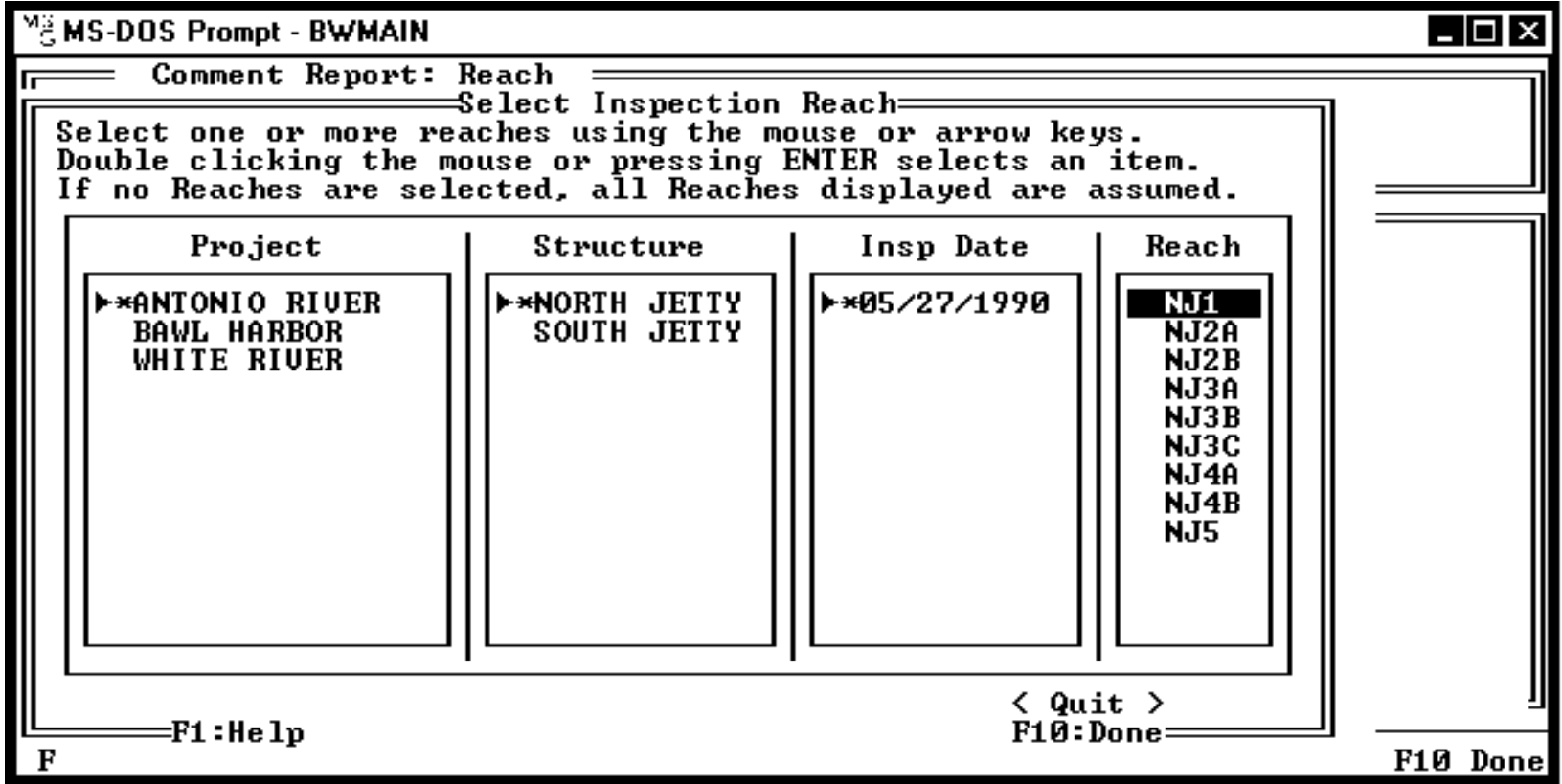

\section{Missing Information Report}

The Missing Information Report has the same menu format as the previously-described reports. This report will give the user a list of items that have not been completed yet. For example, if the user is missing an item in the structural rating categories, this report will show the item that is missing. An example screen is shown at the top of the next page.

\section{Print Inspection Forms}

Selecting the Print Inspection Forms option will give the user a menu listing the types of inspection forms available. The options available include:

1. B)lank Inspection Forms

2. D)ate selected Inspection Forms

3. P)roject selected Inspection Forms

4. S)tructure selected Inspection Forms

5. R)each selected Inspection Forms

See Appendix B for an example of a blank inspection form, and a reach-selected inspection form from the Print Inspection Form options. The other three options operate the same as the Reach option, however, those options will print out all of the reaches within that project, structure, and date. (See example screen on the next page). 


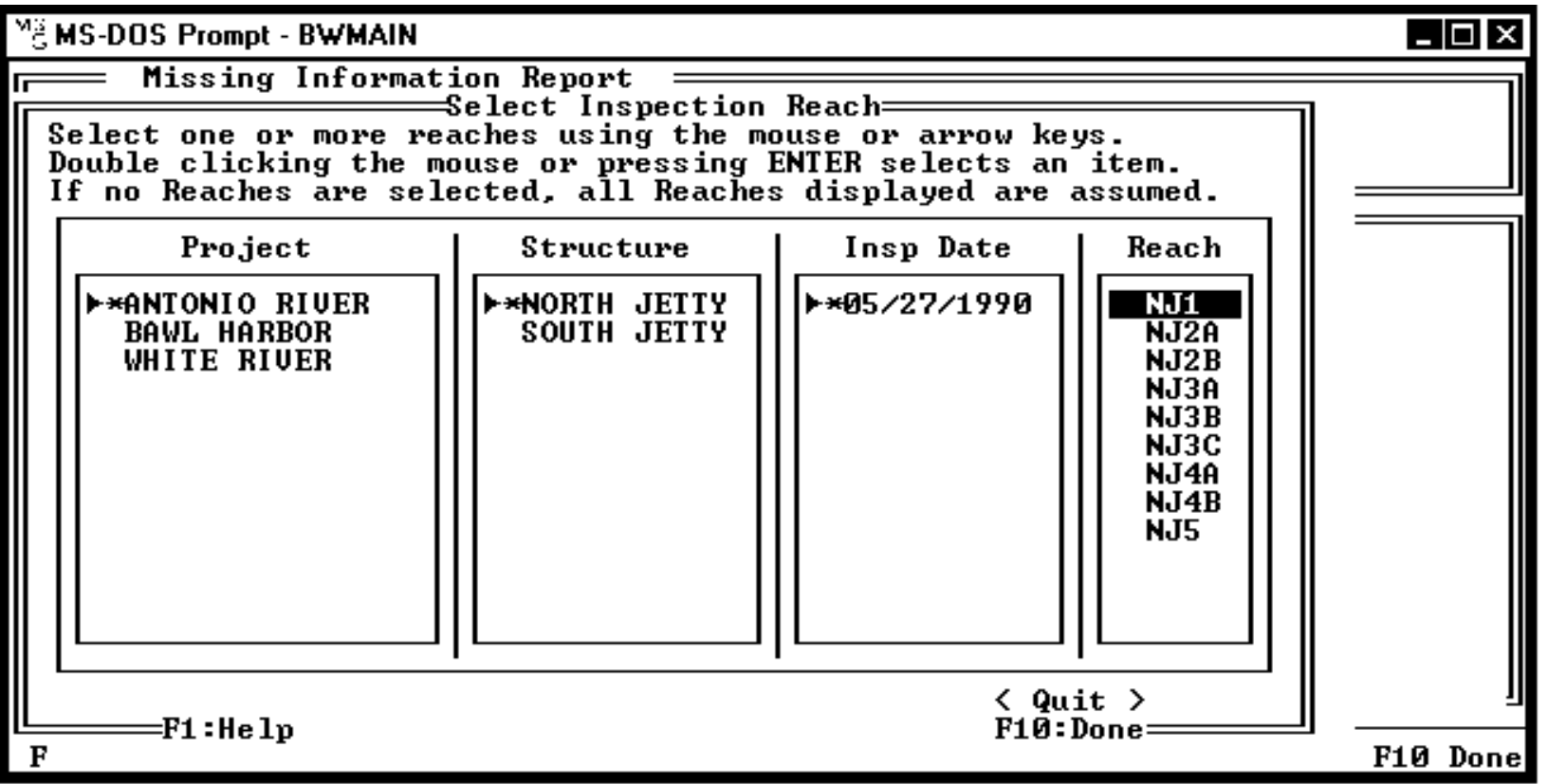

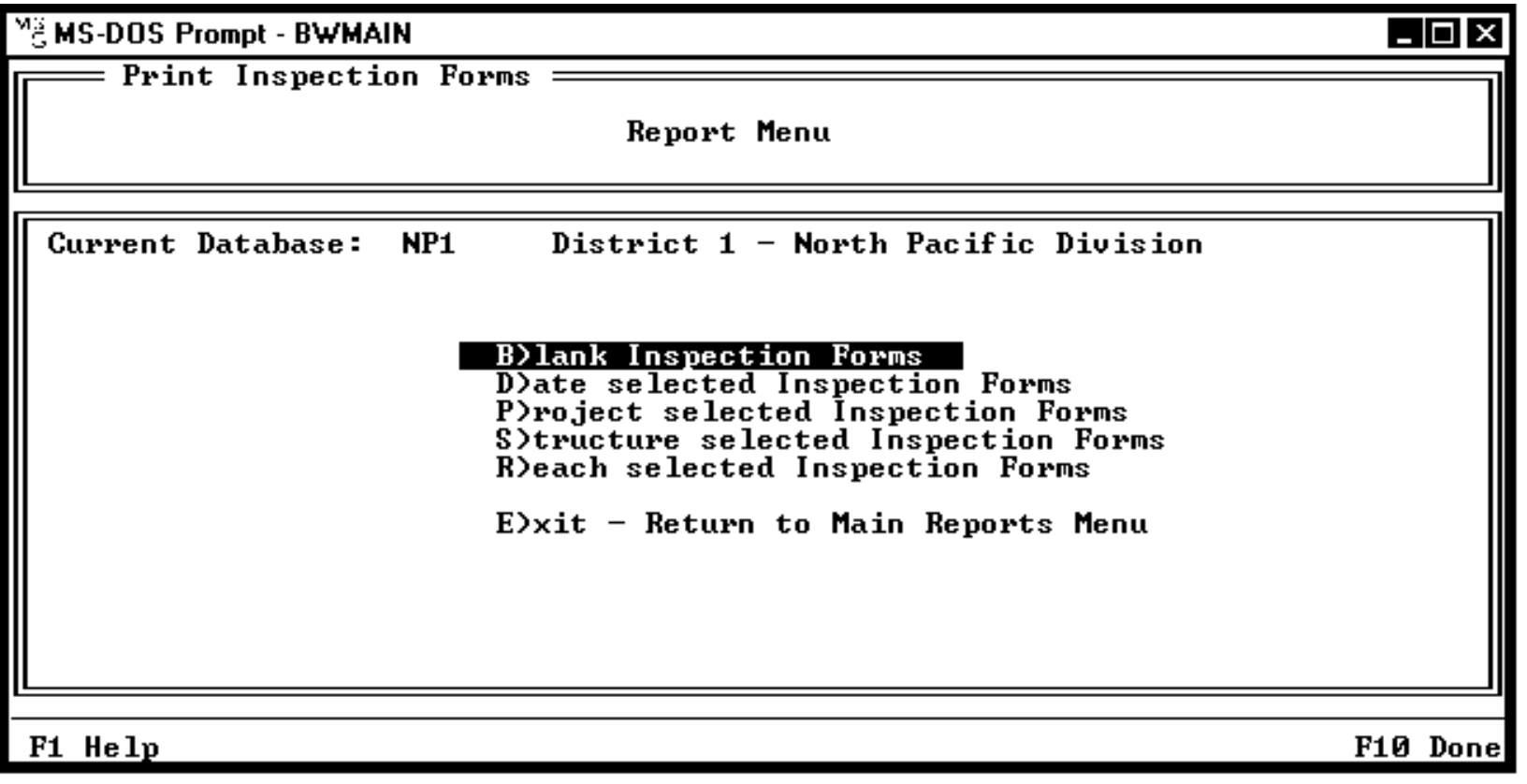




\section{Database Administration}

\section{Introduction}

Selecting Database Administration, option 5 on the Main Menu, will bring you to the Database Administration Menu shown below. To select an option, highlight the desired option and press [ENTER].

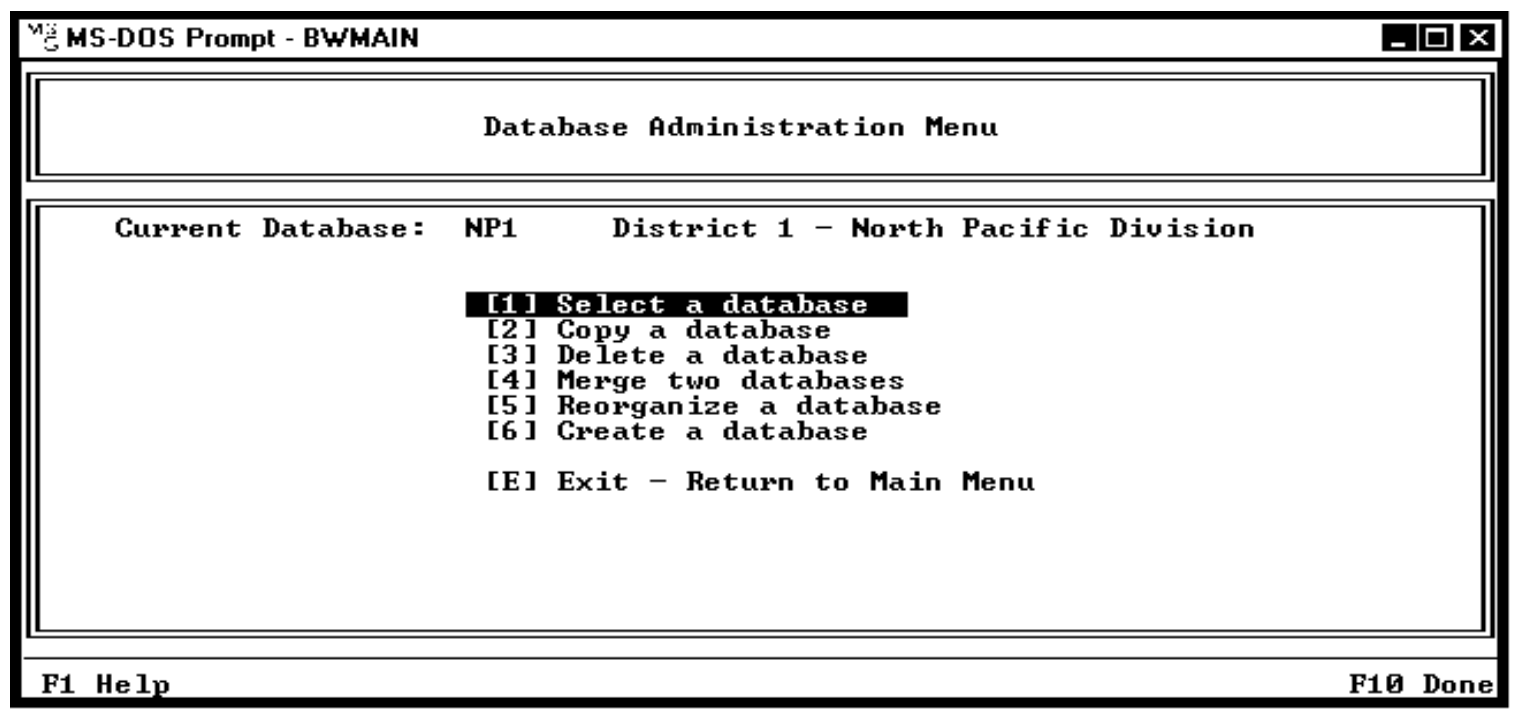

\section{Selecting a Database}

A database must be selected to add, edit or view any data. To select a database, place the highlight bar over Select a Database or press the Number 1. A pop-up screen will then appear that contains a list of current databases. Place the highlight bar over the desired database and press [ENTER] or press the appropriate letter. (See example screen on next page).

\section{Copying a Database}

Copying a database enables the transfer of a BREAKWATER database from one workstation to another and allows making a back-up or modifying a copy on the same drive. To make a copy of a database, highlight Copy a Database and press [ENTER] or press the number 2. (See 
example screen at bottom of page). The Select a Database pop-up screen will appear. Highlight the desired database and press [ENTER] or press the appropriate letter.

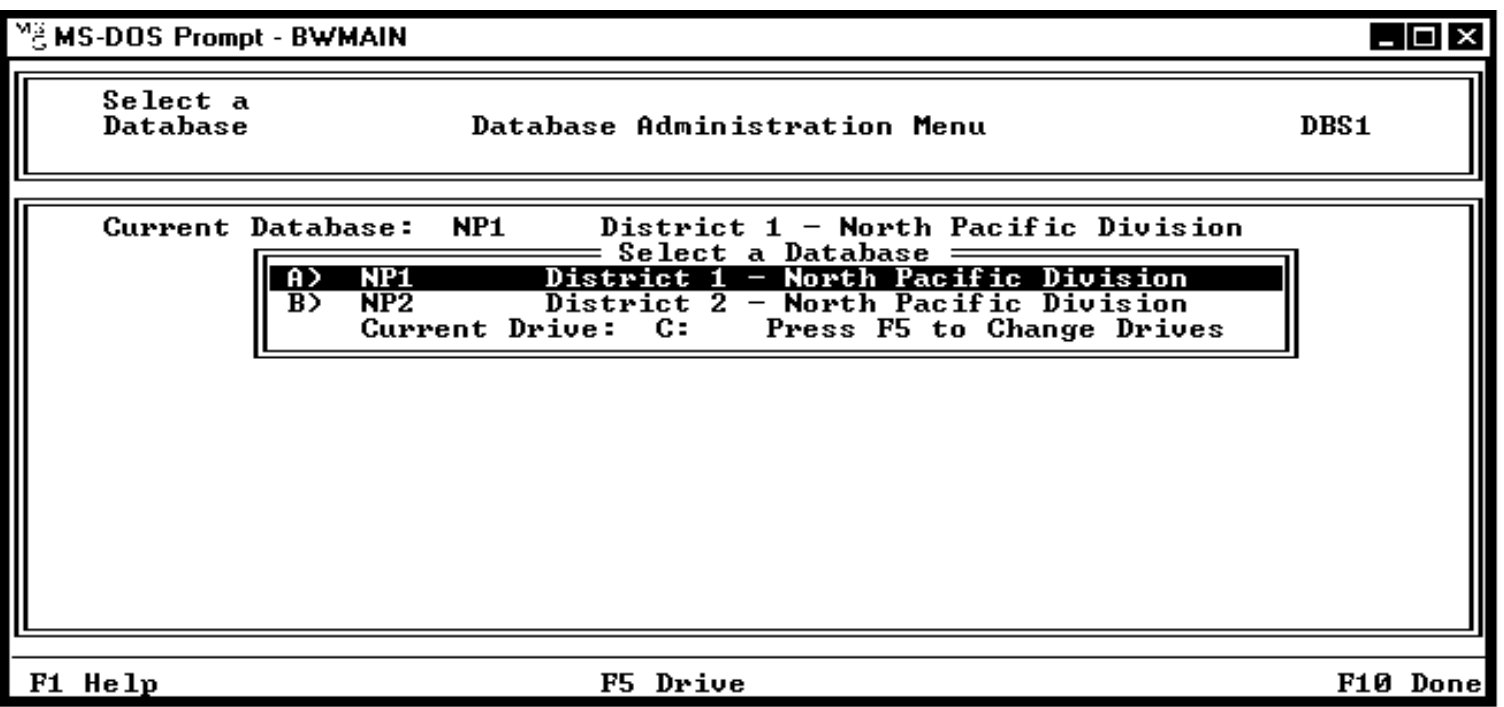

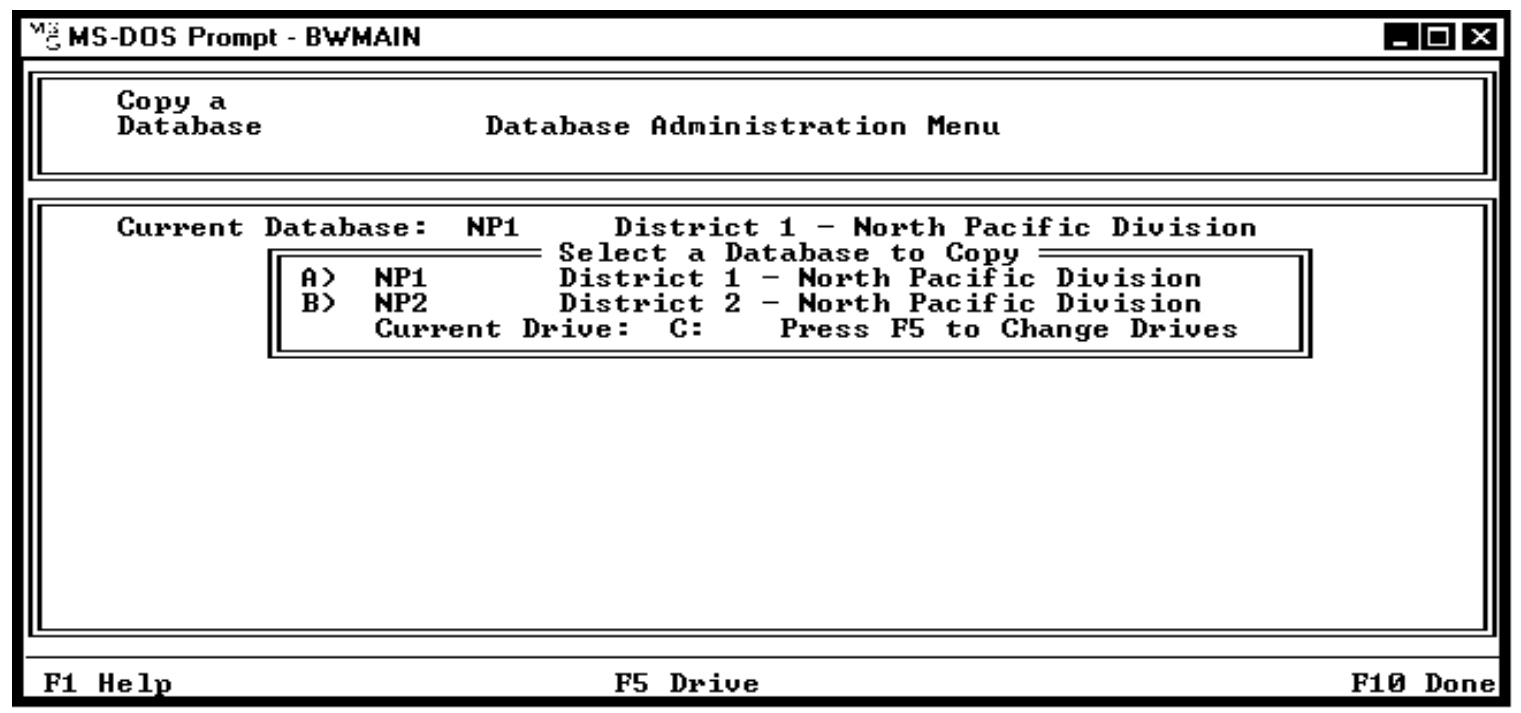


Pressing F5 will allow the user to select a different disk drive; another pop-up screen (as shown below) will appear:

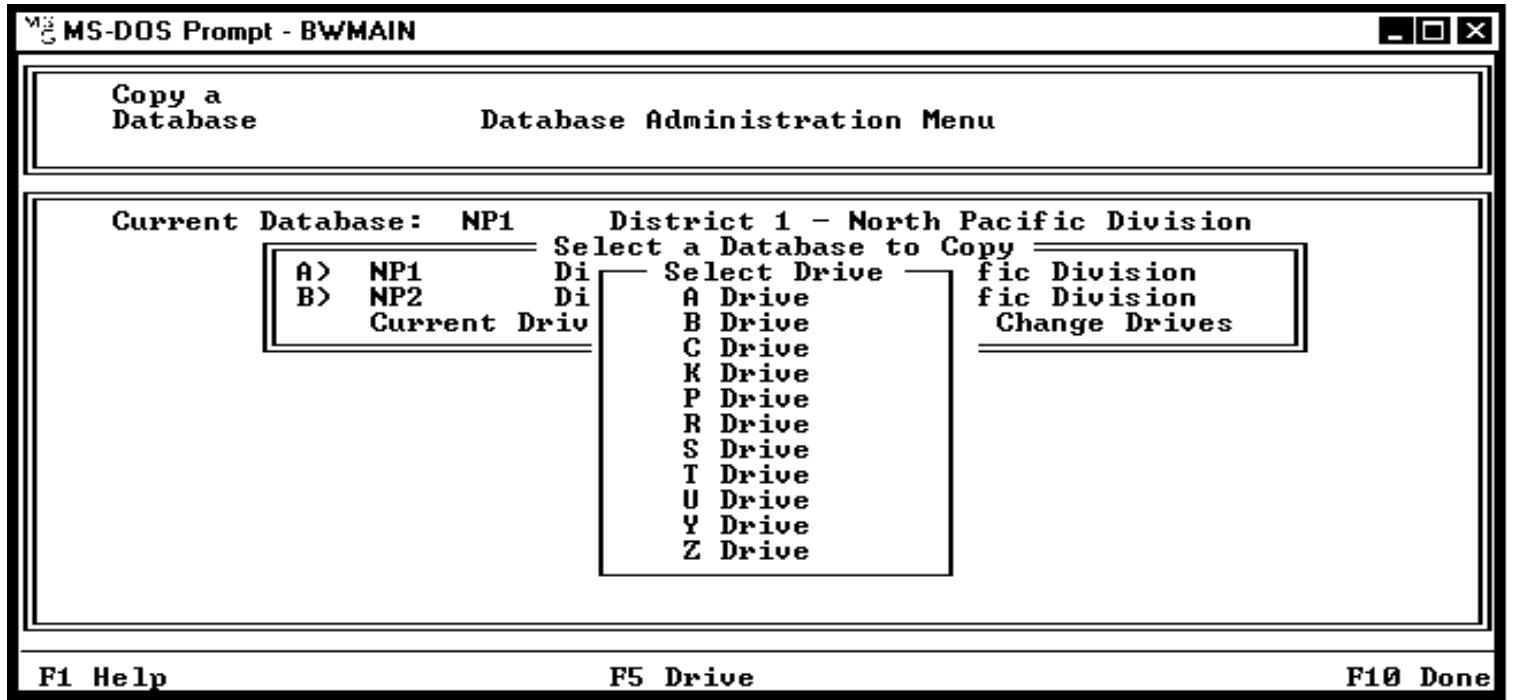

The cursor will be waiting for the user to enter appropriate information and the letter of the disk drive where the copied database is to be written.

\section{Deleting a Database}

When a database is no longer useful and the user wishes to delete it from the disk drive, simply highlight Delete a Database and press [ENTER] or press the Number 3. The Select a Database window will appear and the user will select the database. The Delete a Database pop-up window will appear for the user to verify that the desired database has been correctly selected. If so, press $\mathbf{Y}$ for Yes. (See example screen at top of next page).

\section{Merging Two Databases}

By selecting Merge Two Databases, option 4 on the Database Administration Menu, the user will be able to select two databases to be merged. The user must provide the new database symbol, database title, and disk drive. One database will then be created.

Note that the first database chosen will default as the new database symbol. (See example screen on next page). 


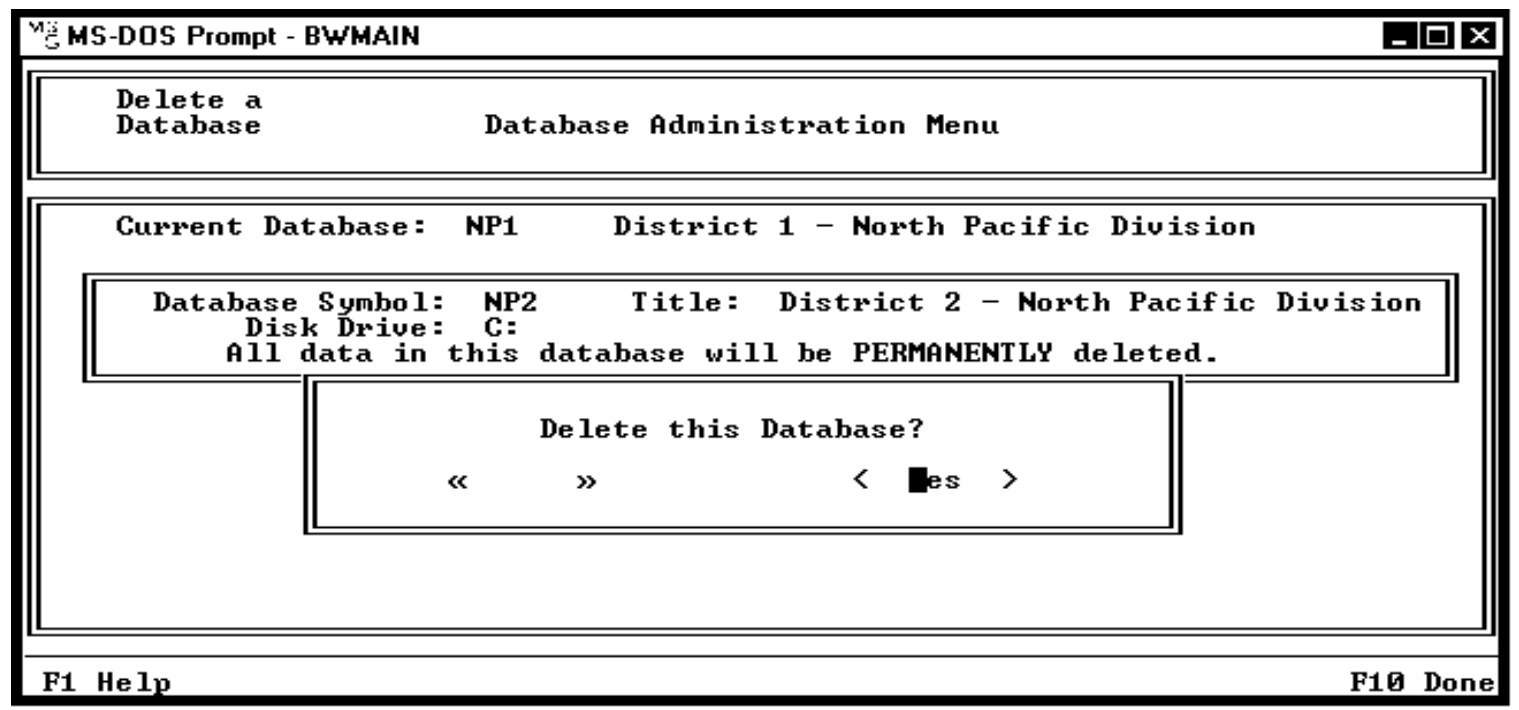

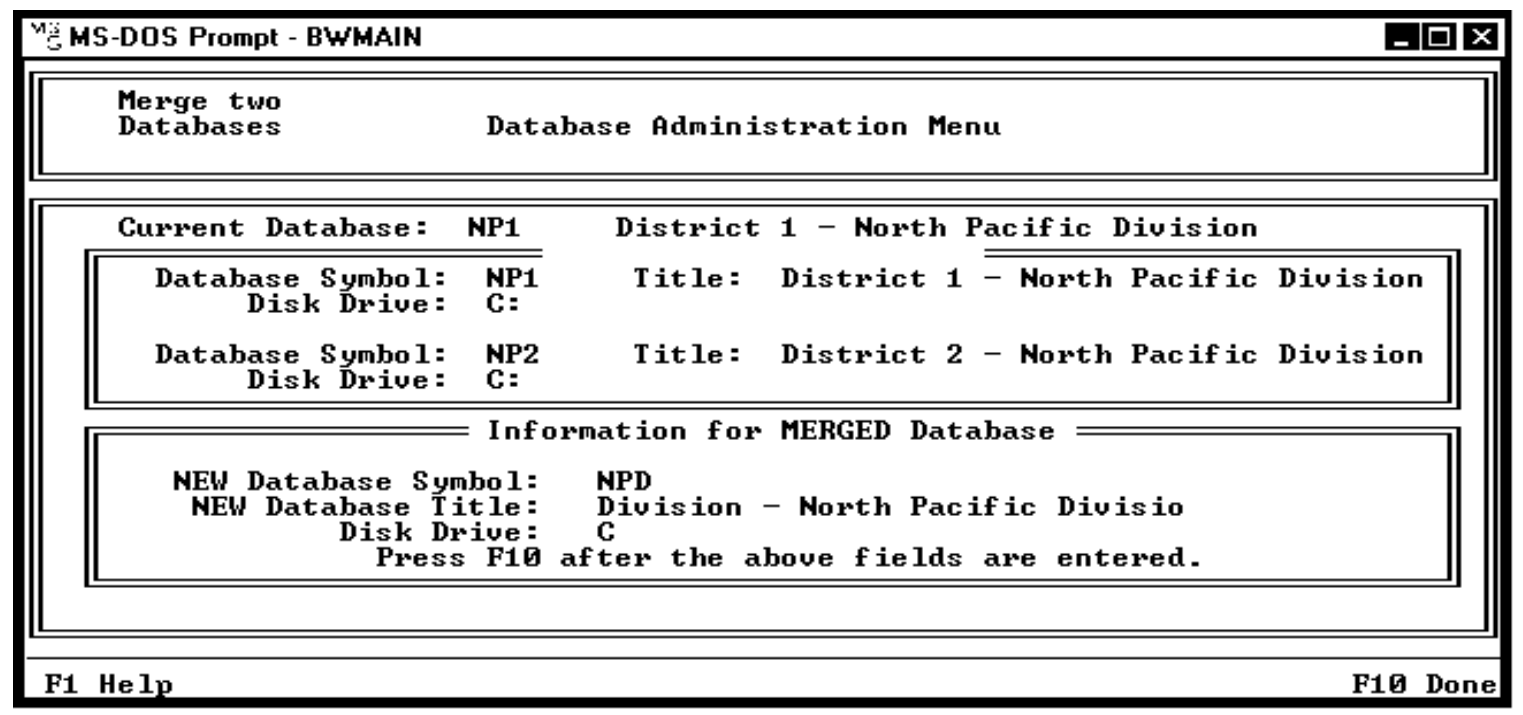

\section{Reorganizing a Database}

By selecting Reorganize a Database, the user is able to recover disk space from deleted entries. No change in the remaining information is made. See example screen on the next page: 


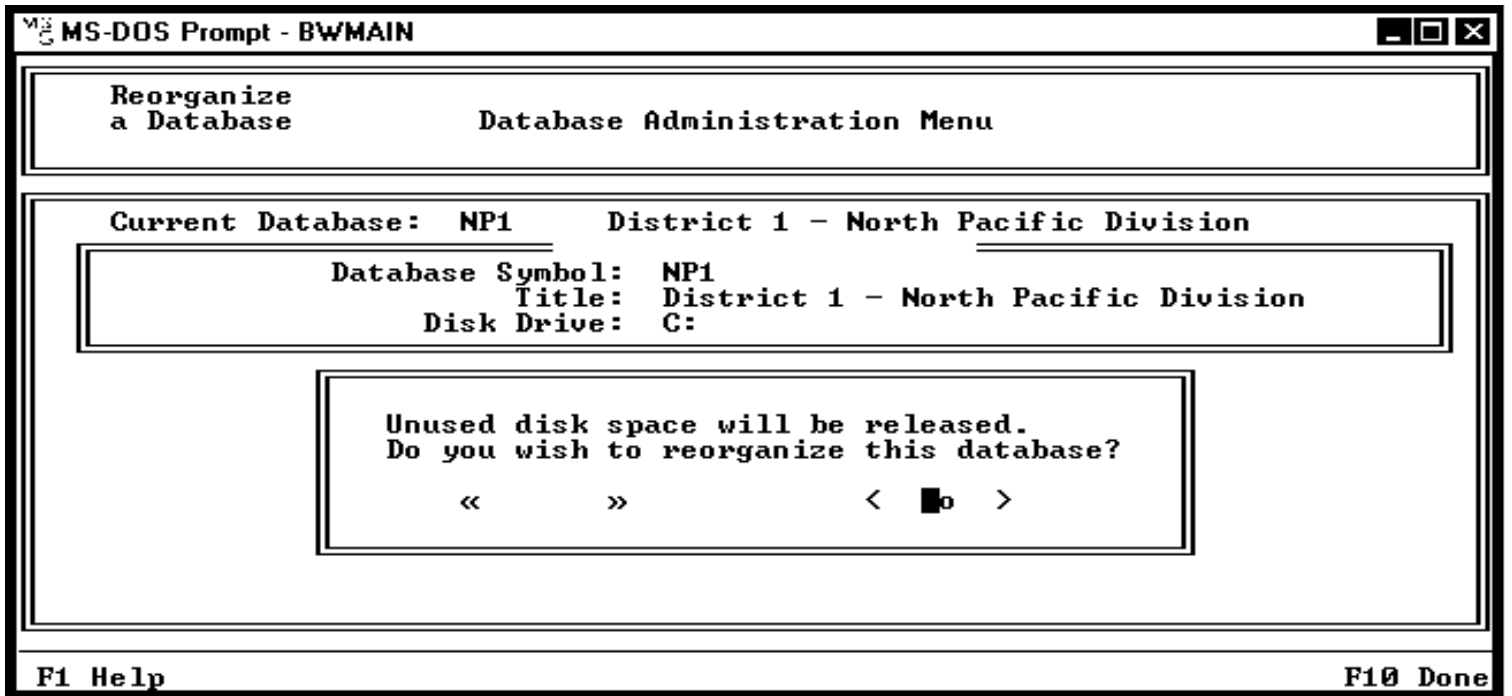

\section{Creating a Database}

The user can create a new database by selecting Create a Database from the Database Administration menu. The user must then provide a database symbol and database title. An example screen is shown below:

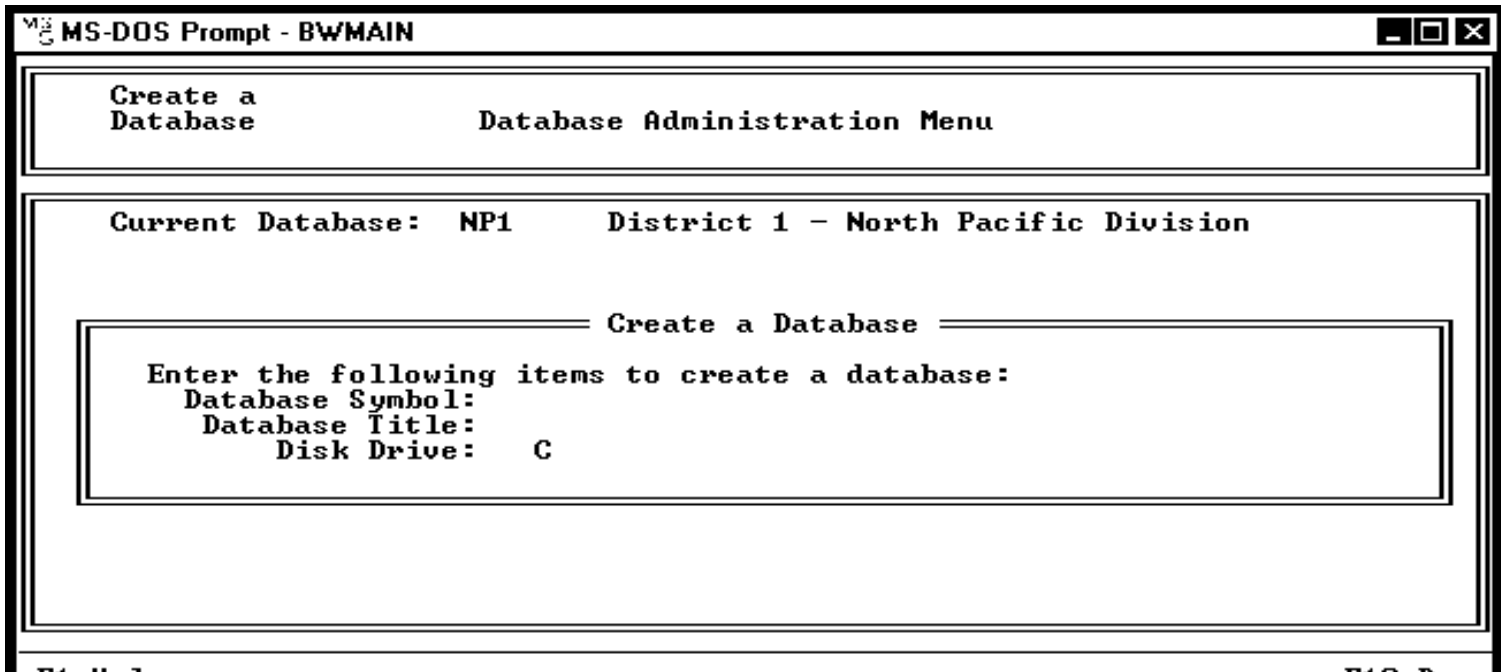




\section{Appendix A: Reports}

District Inventory Summary

Project: Alpha Order

Structural Index:

Structural Index:

Functional Index $(\mathrm{Cl})$ :

Functional Index $(\mathrm{Cl})$ :

Last Inspection Date:

Last Inspection Date:
(ASCENDING)

(ASCENDING)

(DESCENDING)

(ASCENDING)

(DESCENDING)

(ASCENDING)

(DESCENDING)

Condition Index Calc: Reach

Historical Index Rating Summary

Comment Report: Reach

Missing Information Report 


\section{District Inventory Summary}

\section{Project: Alpha Order (ASC)}


DISTRICT INVENTORY SUMMARY

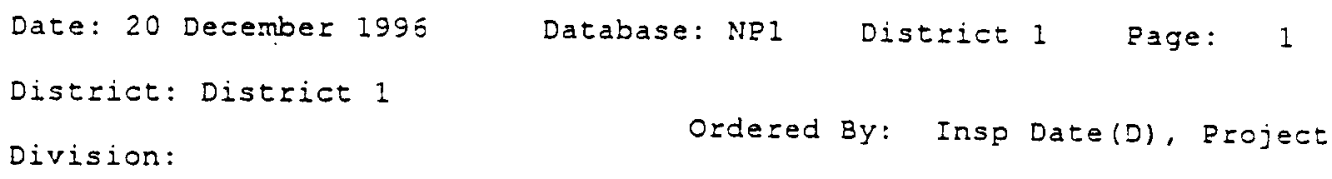

\begin{tabular}{lcccccc} 
Project, State & Structure & $\begin{array}{c}\text { Year } \\
\text { Cmplt }\end{array}$ & $\begin{array}{l}\text { Structure } \\
\text { Length(ft) }\end{array}$ & $\begin{array}{l}\text { Struct } \\
\text { Index }\end{array}$ & $\begin{array}{l}\text { Eunct } \\
\text { Index }\end{array}$ & $\begin{array}{l}\text { Inspecticn } \\
\text { Stat Date }\end{array}$ \\
\hline ANTONIO RIVER, OR & NORTH JETTY & 1967 & 3450 & 71 & 62 & $05 / 27 / 1990$ \\
\hline ANTONIO RIVER, OR & SOUTH JETTY & 1967 & 2650 & 76 & 57 & $05 / 28 / 1990$ \\
\hline BAWL HARBOR, AK & E.BREAKWATER & 1957 & 1750 & 49 & 83 & $05 / 21 / 1990$ \\
\hline BAWL HARBOR, AK & NORTH JETTY & 1957 & 1570 & 48 & 49 & $05 / 18 / 1990$ \\
\hline BAWL HARBOR, AK & S.BREAKWATER & 1957 & 1060 & 78 & 80 & $05 / 16 / 1990$ \\
\hline BAWL HARBOR, AK & SOUTH JETTY & 1957 & 1300 & 65 & 59 & $05 / 17 / 1990$ \\
\hline WHITE RIVER, CA & NORTH JETTY & 1957 & 1970 & 73 & 81 & $05 / 21 / 1990$ \\
\hline WHITE RIVER, CA & SOUTH JETTY & 1957 & 975 & 50 & 55 & $05 / 22 / 1990$ \\
\hline
\end{tabular}

SUMMARY

Lowest Condition Index: 49

Average Condition Index: 67

Highest Condition Index: 83

Total Length of Structures: 14725 


\title{
District Inventory Summary
}

\author{
Structural Index: (ASC) \\ Structural Index: (DESC)
}




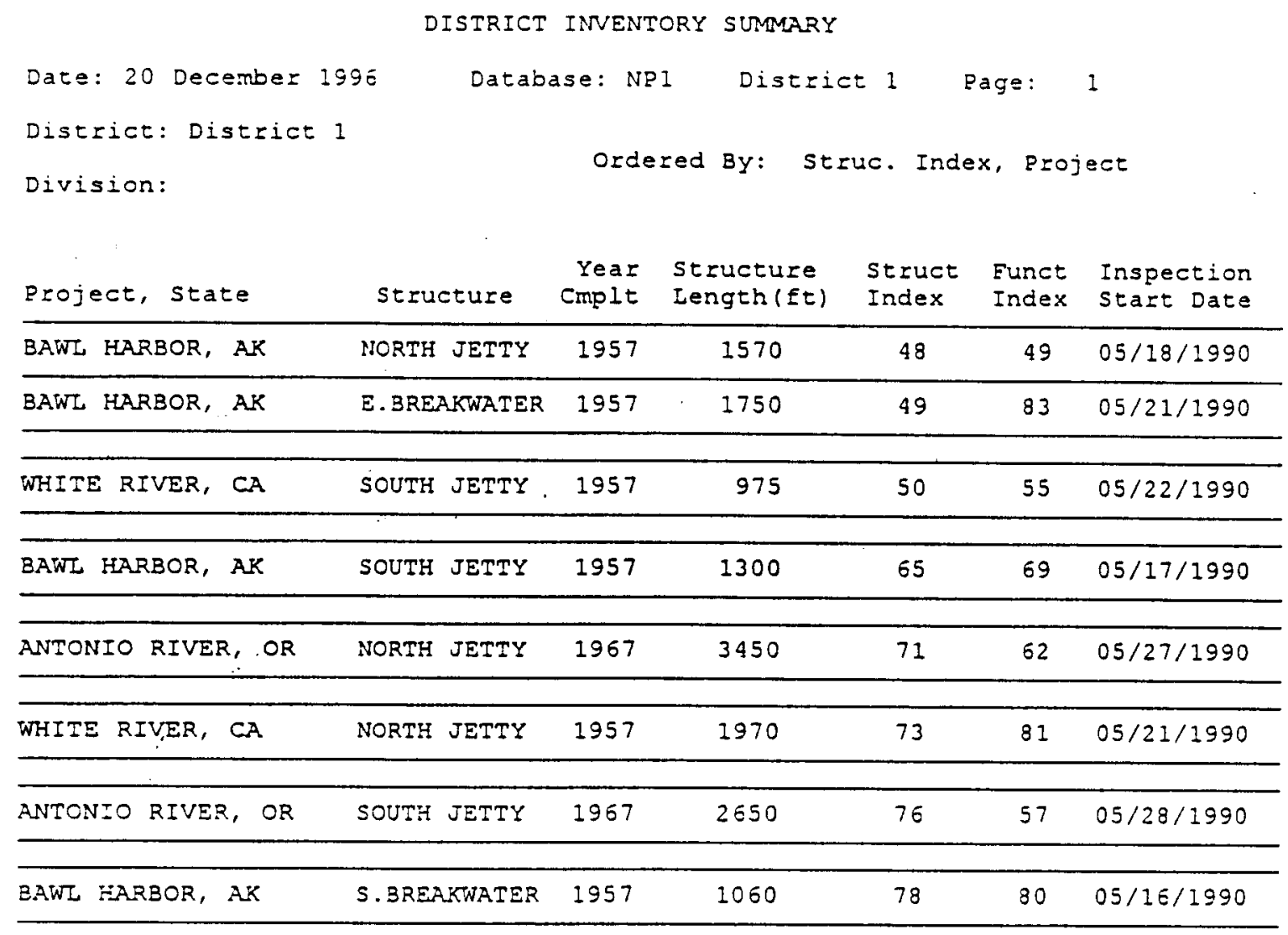

\section{SUMMARY}

$\begin{aligned} \text { Lowest Condition Index: } & 49 \\ \text { Average Condition Index: } & 67 \\ \text { Highest Condition Index: } & 83 \\ \text { Total Length of Structures: } & 14725\end{aligned}$


DISTRICT INVENTORY SUMMARY

Date: 20 December 1996

Distriet 1

Page: 1

District: Distriet 1

Division:

Ordered By: Struc. Index(D), Project

\begin{tabular}{|c|c|c|c|c|c|c|}
\hline Project, state & structure & $\begin{array}{l}\text { Year } \\
\text { Cmplt }\end{array}$ & $\begin{array}{l}\text { seructure } \\
\text { Length (ft) }\end{array}$ & $\begin{array}{l}\text { Struct } \\
\text { Index }\end{array}$ & $\begin{array}{l}\text { Funct } \\
\text { Index }\end{array}$ & $\begin{array}{l}\text { Inspection } \\
\text { Start Date }\end{array}$ \\
\hline BAWL HARBOR, AK & S.BREAKWATER & 1957 & 1060 & 78 & 80 & $05 / 16 / 1990$ \\
\hline ANTONIO RIVER, OR & SOUTH JETTY & 1967 & 2650 & 76 & 57 & $05 / 28 / 1990$ \\
\hline WHITE RIVER, CA & NORTH JETTY & 1957 & 1970 & 73 & 81 & $05 / 21 / 1990$ \\
\hline ANTONIO RIVER, OR & NORTE JETTY & 1967 & 3450 & 71 & 62 & $05 / 27 / 1990$ \\
\hline BANL HARBOR, AK & SOUTH JETTY & 1957 & 1300 & 65 & 69 & $05 / 17 / 1990$ \\
\hline WHITE RIVER, CA & SOUTH JETTY & 1957 & 975 & 50 & 55 & $05 / 22 / 1990$ \\
\hline BAWL HARBOR, AK & E.BREAKWATER & 1957 & 1750 & 49 & 83 & $05 / 21 / 1990$ \\
\hline BANL MARBOR, AK & NORTH JETTY & 1957 & 1570 & 48 & 49 & $05 / 18 / 1990$ \\
\hline
\end{tabular}

SUMMARY

Lowest Condition Index: 49

Average Condition Index: 67

Highest Condition Index: 83

Total Iength of Structures: 14725 


\section{District Inventory Summary}

\section{Functional Index (CI): (ASC) \\ Functional Index (CI): DESC)}


DISTRICT INVENTORY SUMMARY

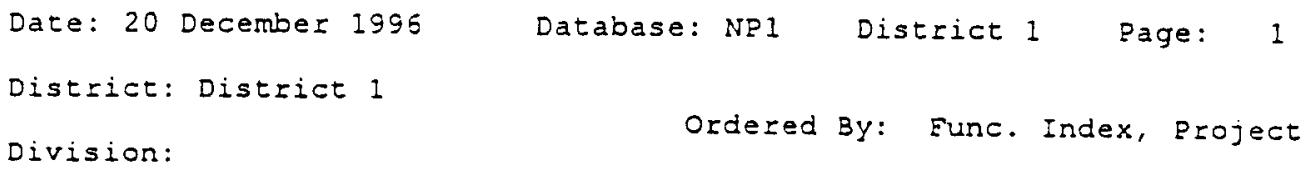

\begin{tabular}{|c|c|c|c|c|c|c|}
\hline Project, state & structure & $\begin{array}{l}\text { Year } \\
\text { Cmplt }\end{array}$ & $\begin{array}{l}\text { structure } \\
\text { Length (ft) }\end{array}$ & $\begin{array}{l}\text { Struct } \\
\text { Index }\end{array}$ & $\begin{array}{l}\text { Funct } \\
\text { Index }\end{array}$ & $\begin{array}{l}\text { Inspection } \\
\text { Start Date }\end{array}$ \\
\hline BAWL HARBOR, AK & NORTH JETTY & 1957 & 1570 & 48 & 49 & $05 / 18 / 1990$ \\
\hline WHITE RIVER, CA & SOUTH JETTY & 1957 & 975 & 50 & 55 & $05 / 22 / 1990$ \\
\hline ANTONIO RIVER, OR & SOUTH JETTY & 1967 & 2650 & 76 & 57 & $05 / 28 / 1990$ \\
\hline ANTONIO RIVER, OR & NORTH JETTY & 1967 & 3450 & 71 & 62 & $05 / 27 / 1990$ \\
\hline BAWL HARBOR, AK & SOUTH JETTY & 1957 & 1300 & 65 & 69 & $05 / 17 / 1990$ \\
\hline BAWL HARBOR, AK & S.BREAKWATER & 1957 & 1060 & 78 & 80 & $05 / 16 / 1990$ \\
\hline WHITE RIVER, CA & NORTH JETTY & 1957 & 1970 & 73 & 81 & $05 / 21 / 1990$ \\
\hline BAWL HARBOR, AK & E. BREAKWATER & 1957 & 1750 & 49 & 83 & $05 / 21 / 1990$ \\
\hline
\end{tabular}

SUMMARY

$\begin{aligned} \text { Lowest Condition Index: } & 49 \\ \text { Average Condition Index: } & 67 \\ \text { Highest Condition Index: } & 83 \\ \text { Total Length of Structures: } & 14725\end{aligned}$


DISTRICT INVENTORY SUMMARY

\begin{tabular}{|c|c|c|c|c|c|c|}
\hline \multirow{2}{*}{$\begin{array}{l}\text { Division: } \\
\text { Project, state }\end{array}$} & \multirow[b]{2}{*}{ structure } & \multicolumn{2}{|c|}{ Ordered By: Func. } & \multicolumn{3}{|c|}{ - Index $(D)$, Project } \\
\hline & & $\begin{array}{r}\text { Year } \\
\text { Cmplt }\end{array}$ & $\begin{array}{l}\text { Structure } \\
\text { Length (ft) }\end{array}$ & $\begin{array}{l}\text { Struct } \\
\text { Index }\end{array}$ & $\begin{array}{l}\text { Funct } \\
\text { Index }\end{array}$ & $\begin{array}{l}\text { Inspection } \\
\text { Start Date }\end{array}$ \\
\hline BAWL HARBOR, AK & E.BREAKWATER & 1957 & 1750 & 49 & 83 & $05 / 21 / 1990$ \\
\hline WHITE RIVER, CA & NORTH JETTY & 1957 & 1970 & 73 & 81 & $05 / 21 / 1990$ \\
\hline BAWL HARBOR, AK & S.BREAKWATER & 1957 & $10 € 0$ & 78 & 80 & $05 / 16 / 1990$ \\
\hline BAWL HARBOR, AK & SOUTH JETTY & 1957 & 1300 & 65 & 69 & $05 / 17 / 1990$ \\
\hline ANTONIO RIVER, OR & NORTH JETTY & 1967 & 3450 & 71 & 62 & $05 / 27 / 1990$ \\
\hline ANTONIO RIVER, OR & SOUTH JETTY & 1967 & 2650 & 76 & 57 & $05 / 28 / 1990$ \\
\hline$\therefore$ & & & & & & \\
\hline WHITE RIVER, CA & SOUTH JETTY & 1957 & 975 & 50 & 55 & $05 / 22 / 1990$ \\
\hline BAWL HARBOR, AR & NORTH JETTY & 1957 & 1570 & 48 & 49 & $05 / 18 / 1990$ \\
\hline
\end{tabular}

SURMARY

Lowest Condition Index: 49

Average Condition Index: 67

Highest Condition Index: 83

Total Length of Structures: 14725 


\section{District Inventory Summary}

\section{Last Inspection Date: (ASC) Last Inspection Date: (DESC)}




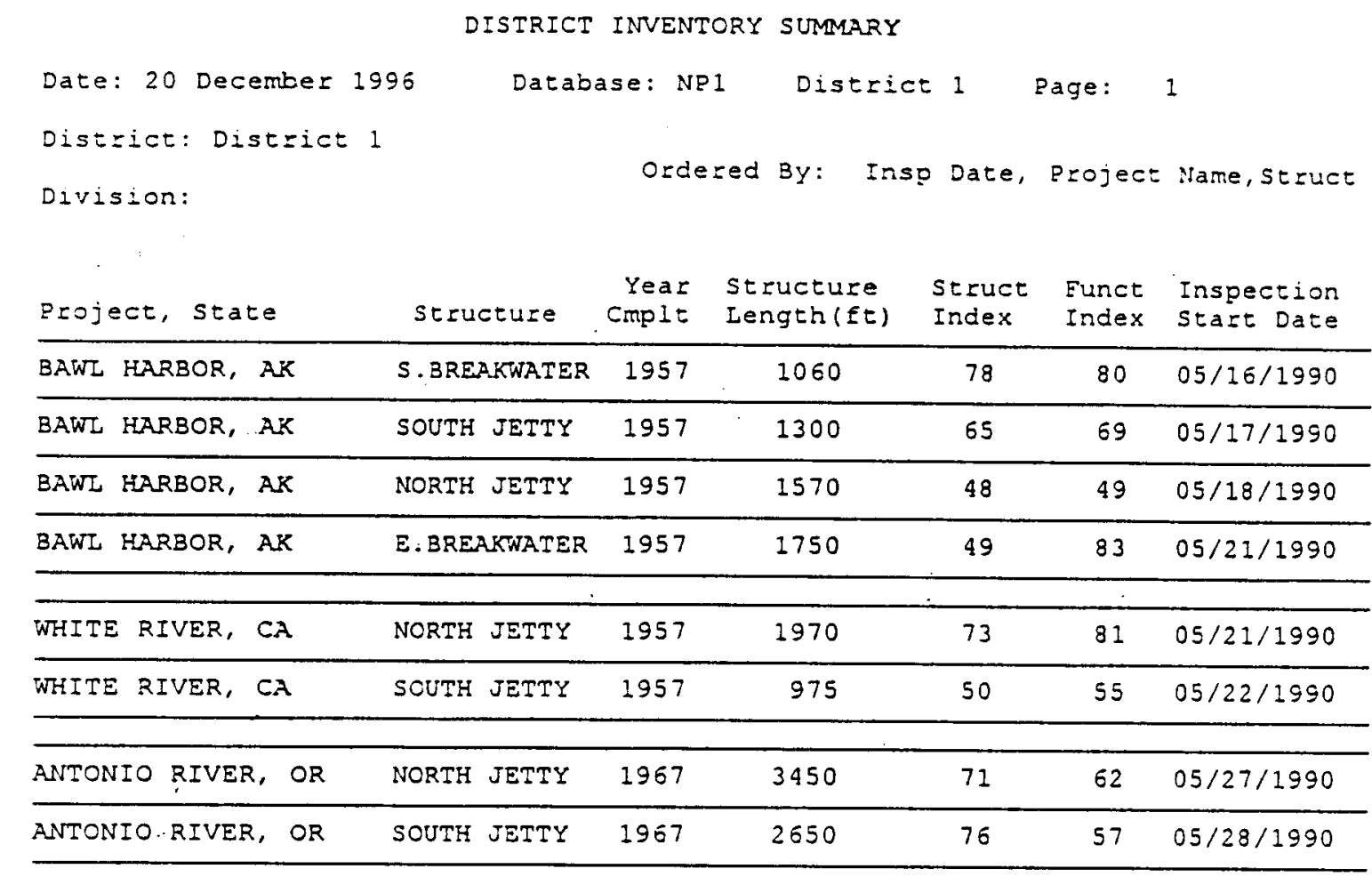

\section{SUMMARY}

Lowest Condition Index: 49

Average Condition Index: 67

Highest Condition Index: 83

Total Length of Structures: 14725 
DISTRICT INVENTORY SUMMARY

Date: 20 December 1996

District: District 1

Division:
Database: NP1 District 1 Page: 1

Ordered By: Project Name, Year Const(D)

\begin{tabular}{lcccccc} 
Project, State & Structure & $\begin{array}{c}\text { Year } \\
\text { Cmplt }\end{array}$ & $\begin{array}{l}\text { Structure } \\
\text { Iength(ft) }\end{array}$ & $\begin{array}{c}\text { Struct } \\
\text { Index }\end{array}$ & $\begin{array}{l}\text { Funct } \\
\text { Index }\end{array}$ & $\begin{array}{l}\text { Inspection } \\
\text { Start Date }\end{array}$ \\
\hline ANTONIO RIVER, OR & NORTH JETTY & 1967 & 3450 & 71 & 62 & $05 / 27 / 1990$ \\
\hline ANTONIO RIVER, OR & SOUTH JETTY & 1967 & 2650 & 76 & 57 & $05 / 28 / 1990$ \\
\hline BAWL HARBOR, AR & E.BREAKWATER & 1957 & 1750 & 49 & 83 & $05 / 21 / 1990$ \\
\hline BAWL HARBOR, AK & NORTH JETTY & 1957 & 1570 & 48 & 49 & $05 / 18 / 1990$ \\
\hline BAWL HARBOR, AK & S.BREAKWATER & 1957 & 1060 & 78 & 80 & $05 / 16 / 1990$ \\
\hline BANL HARBOR, AK & SOUTH JETTY & 1957 & 1300 & 65 & 69 & $05 / 17 / 1990$ \\
\hline WEITE RIVER, CA & NORTH JETTY & 1957 & 1970 & 73 & 81 & $05 / 21 / 1990$ \\
\hline WTITE REVER, CA & SOUTH JETTY & 1957 & 975 & 50 & 55 & $05 / 22 / 1990$ \\
\hline
\end{tabular}

SUMMARY

Lowest Condition Index: 49

Average Condition Index: 67

Highest Condition Index: 83

Sotal Length of structures: 14725 


\section{Condition Index Calc: Reach}




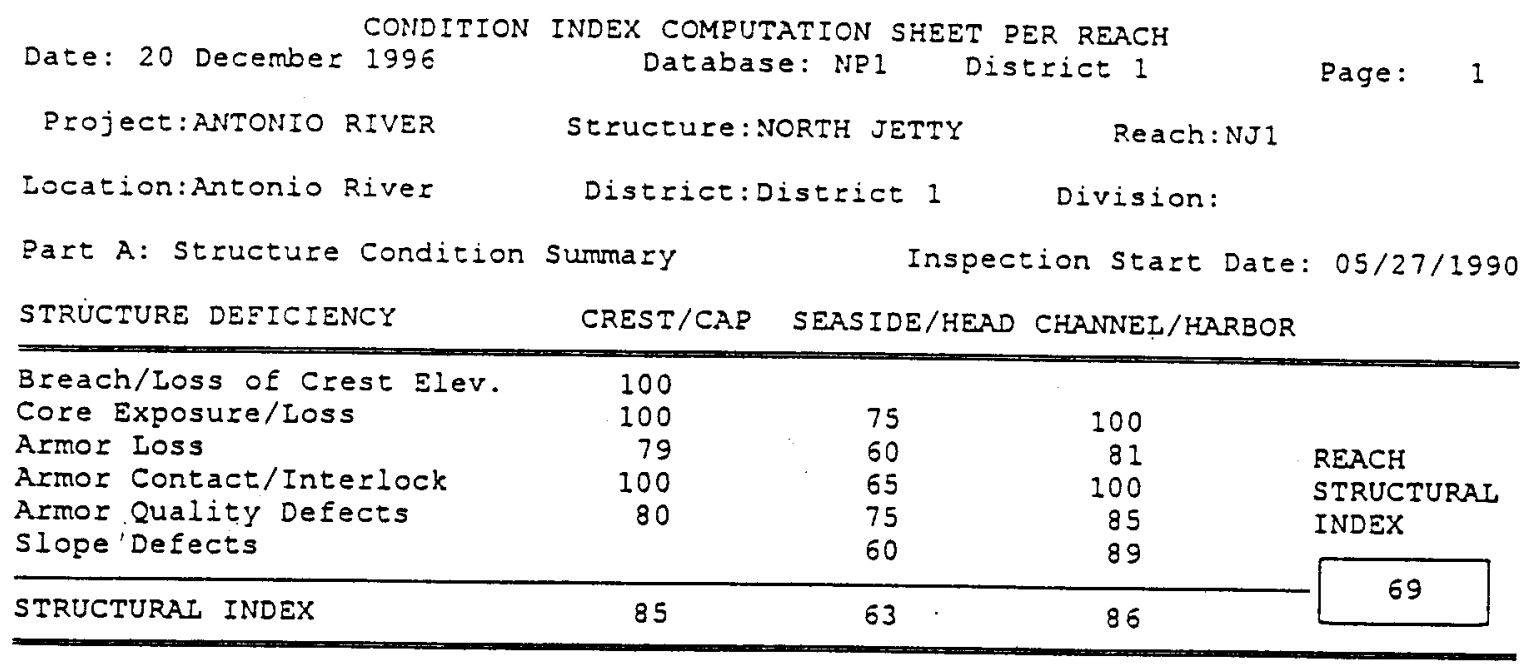

Are there functional deficiencies which are NOT related to structural defects?
(YES NO) $=$ NO

Is there risk of further major loss of function within the next budget cycle?

(ratings not included in CI calculation are marked with an *)

Part B: Functional Rating Summary

\begin{tabular}{|c|c|c|c|c|}
\hline \multicolumn{2}{|c|}{ FUNCTION } & \multicolumn{2}{|r|}{$\begin{array}{l}\text { RECOMMENDED } \\
\text { ACTION }\end{array}$} & \\
\hline $\begin{array}{l}\text { HARBOR } \\
\text { AREA }\end{array}$ & $\begin{array}{l}\text { Harbor Use } \\
\text { a.Moored Vessels } \\
\text { b. Harbor Structure } \\
\text { c.other Eacilities }\end{array}$ & & & \\
\hline $\begin{array}{l}\text { NAVIGATION } \\
\text { CHANNEL }\end{array}$ & $\begin{array}{l}\text { Entrance Use } \\
\text { Channel }\end{array}$ & & & \\
\hline $\begin{array}{l}\text { SEDIMENT } \\
\text { MANAGEMENT }\end{array}$ & $\begin{array}{l}\text { Ebb Shoal } \\
\text { Flood Shoal } \\
\text { Harbor Shoal } \\
\text { Shoreline Impacts }\end{array}$ & $\begin{array}{l}50 \\
70\end{array}$ & $\begin{array}{l}\text { Act soon } \\
\text { Act soon }\end{array}$ & $\begin{array}{l}\text { REACH } \\
\text { EUNCTIONAL } \\
\text { INDEX }\end{array}$ \\
\hline $\begin{array}{l}\text { STRUCTURE } \\
\text { PROTECTION }\end{array}$ & $\begin{array}{l}\text { Nearby Structures } \\
\text { *Toe Erosion } \\
\text { *Trunk Protection }\end{array}$ & $\begin{array}{l}80 \\
84\end{array}$ & $\begin{array}{l}\text { Watch } \\
\text { Act Soon }\end{array}$ & 54 \\
\hline $\begin{array}{l}\text { OTHER } \\
\text { EUNCTIONS }\end{array}$ & $\begin{array}{l}\text { Public Access } \\
\text { Recreational Use } \\
\text { Environmental Effect } \\
\text { Aids to Navigation }\end{array}$ & & & \\
\hline
\end{tabular}




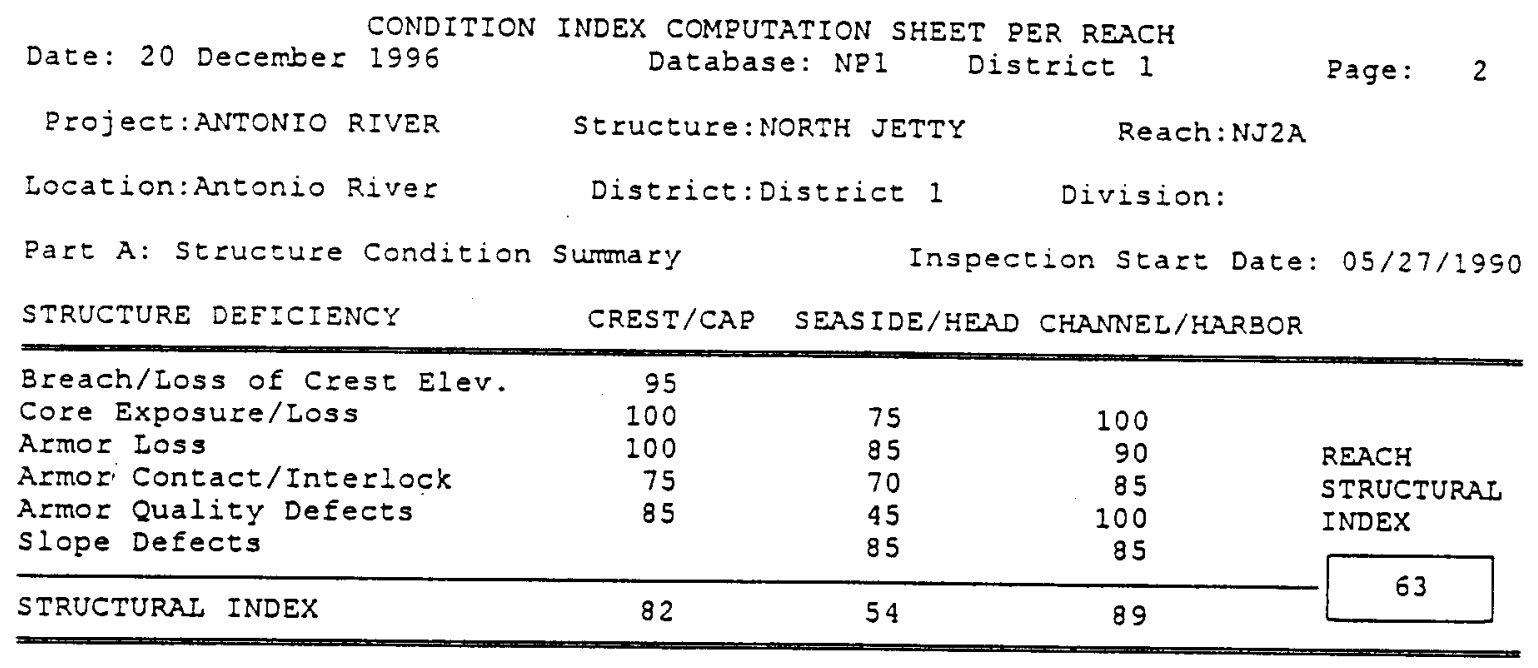

Are there functional deficiencies which are NOT related to structural defects?
(YES NO) = NO

Is there'risk of further major loss of function within the next budget cycle?
(YES NO) $=$ NO

(ratings not included in CI calculation are marked with an *)

Part B: Functicnal Rating Summary

\begin{tabular}{|c|c|c|c|c|}
\hline \multicolumn{2}{|c|}{ FUNCTION } & \multirow{2}{*}{$\begin{array}{c}\text { RATING } \\
80 \\
75 \\
70 \\
70\end{array}$} & \multirow{2}{*}{$\begin{array}{l}\text { RECOMMENDED } \\
\text { ACTION } \\
\text { None } \\
\text { Watch } \\
\text { Watch } \\
\text { Natch }\end{array}$} & \\
\hline $\begin{array}{l}\text { HARECR } \\
\text { AREA. }\end{array}$ & $\begin{array}{l}\text { Harbor Use } \\
\text { a.Moored Vessels } \\
\text { b.Harbor Structure } \\
\text { c.othez Eacilities }\end{array}$ & & & \\
\hline $\begin{array}{l}\text { NAVIGATION } \\
\text { CHANNEL }\end{array}$ & $\begin{array}{l}\text { Entrance Use } \\
\text { Channel }\end{array}$ & 85 & & \\
\hline $\begin{array}{l}\text { SEDIMENT } \\
\text { MANAGEMENT }\end{array}$ & $\begin{array}{l}\text { Ebb Shoal } \\
\text { Elood Shoal } \\
\text { Harbor Shoal } \\
\text { Shoreline Impacts }\end{array}$ & $\begin{array}{l}55 \\
60 \\
60\end{array}$ & Inv $<>$ gate & $\begin{array}{l}\text { REACH } \\
\text { EUNCTIONAL } \\
\text { INDEX }\end{array}$ \\
\hline $\begin{array}{l}\text { STRUCTURE } \\
\text { PROTECTION }\end{array}$ & $\begin{array}{l}\text { Nearby Structures } \\
\text { *Toe Erosion } \\
\text { *Trunk Brotection }\end{array}$ & 70 & & 60 \\
\hline $\begin{array}{l}\text { OTHER } \\
\text { FUNCTIONS }\end{array}$ & $\begin{array}{l}\text { Public Access } \\
\text { Recreational Use } \\
\text { Environmental Effect } \\
\text { Aids to Navigation }\end{array}$ & & Watch & \\
\hline
\end{tabular}




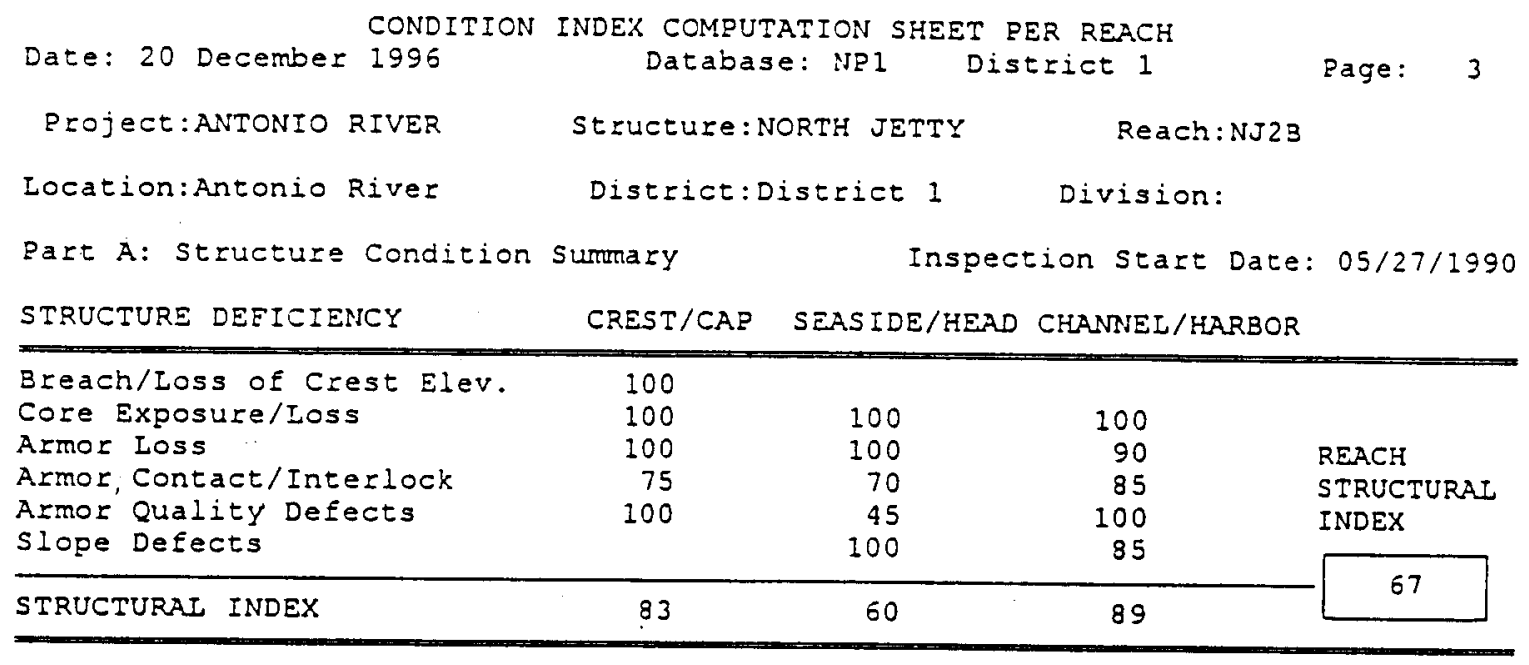

Are there functional deficiencies which are NOT related to structural defects? (YSS NO) = NO

Is there risk of further major loss of function within the next budget cycle? (YES NO) $=$ NO

(ratings not included in CI calculation are marked with an *)

Part B: Functional Rating Summary

\begin{tabular}{|c|c|c|c|c|}
\hline \multicolumn{2}{|c|}{ EUNCTION } & \multicolumn{2}{|r|}{$\begin{array}{l}\text { RECOMMENDED } \\
\text { ACIION }\end{array}$} & \\
\hline $\begin{array}{l}\text { HARBOR } \\
\text { AREA }\end{array}$ & $\begin{array}{l}\text { Harbor Use } \\
\text { a.Moored Vessels } \\
\text { b.Harbor Structure } \\
\text { c.other Facilities }\end{array}$ & $\begin{array}{l}80 \\
75 \\
70 \\
70\end{array}$ & Watch & \\
\hline $\begin{array}{l}\text { NAVIGATION } \\
\text { CHANNEL }\end{array}$ & $\begin{array}{l}\text { Entrance Use } \\
\text { Channel }\end{array}$ & 85 & & \\
\hline $\begin{array}{l}\text { SEDIMENT } \\
\text { MANAGEMENT }\end{array}$ & $\begin{array}{l}\text { Ebb Shoal } \\
\text { Elood Shoal } \\
\text { Harbor Shoal } \\
\text { Shoreline Impacts }\end{array}$ & $\begin{array}{l}55 \\
60 \\
60\end{array}$ & Inv $<>$ gate & $\begin{array}{l}\text { REACH } \\
\text { FUNCTIONAL } \\
\text { INDEX }\end{array}$ \\
\hline $\begin{array}{l}\text { STRUCTURE } \\
\text { PROTECTION }\end{array}$ & $\begin{array}{l}\text { Nearby Structures } \\
\text { *Toe Erosion } \\
\text { *Trunk Protection }\end{array}$ & 70 & & 60 \\
\hline $\begin{array}{l}\text { OTHER } \\
\text { FUNCTIONS }\end{array}$ & $\begin{array}{l}\text { Public Access } \\
\text { Recreational Use } \\
\text { Environmental Effect } \\
\text { Aids to Navigation }\end{array}$ & & & \\
\hline
\end{tabular}




\begin{tabular}{|c|c|c|c|c|}
\hline Date: 20 December 1996 & \multicolumn{3}{|c|}{ INDEX COMPUTATION SHEET PER REACH } & \multirow{2}{*}{ Page: } \\
\hline Project:ANTONIO RIVER & Structure: : & DRTH JETEY & Reach: NJ $3 A$ & \\
\hline Location: Antonio River & District: I & strict 1 & Division: & \\
\hline Part A: Structure Condition & summa ry & Inspect & Eion Start Date: & $05 / 27 / 1990$ \\
\hline STRUCTURE DEFICIENCY & CREST/CAP & SEASIDE/HEAD & CHANNEL/HARBOR & \\
\hline $\begin{array}{l}\text { Breach/Loss of Crest Elev. } \\
\text { Core Exposure/Loss } \\
\text { Armor Loss } \\
\text { Armoz Contact/Interlock } \\
\text { Armor Quality Defects } \\
\text { slope Defects }\end{array}$ & $\begin{array}{r}100 \\
100 \\
55 \\
85 \\
80\end{array}$ & $\begin{array}{r}100 \\
85 \\
60 \\
100 \\
100\end{array}$ & $\begin{array}{l}100 \\
100 \\
100 \\
100 \\
100\end{array}$ & $\begin{array}{l}\text { REACH } \\
\text { STRUCTURAL } \\
\text { INDEX }\end{array}$ \\
\hline STRUCTURAL INDEX & 67 & 71 & 100 & \\
\hline
\end{tabular}

Are there functional deficiencies which are NOT related to structural defects? (YES NO) = NO

Is there risk of Eurther major loss of function within the next budget cycle? (YIS NO) = NO

(zatings not included in CI calculation are marked with an *)

Part B: Functional Rating summary

\begin{tabular}{|c|c|c|c|c|}
\hline \multicolumn{2}{|c|}{ EUNCTION } & \multicolumn{2}{|r|}{$\begin{array}{c}\text { RECOMMENDED } \\
\text { ACTION }\end{array}$} & \\
\hline $\begin{array}{l}\text { HARBOR } \\
\text { AREA }\end{array}$ & $\begin{array}{l}\text { Harbor Use } \\
\text { a.Moored Vessels } \\
\text { b.Harbor Structure } \\
\text { c.Other Eacilities }\end{array}$ & $\begin{array}{l}85 \\
85 \\
85 \\
75\end{array}$ & Watch & \\
\hline $\begin{array}{l}\text { NAVIGATION } \\
\text { CHANIEI }\end{array}$ & $\begin{array}{l}\text { Entrance Use } \\
\text { Channe! }\end{array}$ & $\begin{array}{l}90 \\
90\end{array}$ & & \\
\hline $\begin{array}{l}\text { SEDIMENT } \\
\text { MANAGEMENT }\end{array}$ & $\begin{array}{l}\text { Ebb Shoal } \\
\text { Elood Shoal } \\
\text { Harbor Shoal } \\
\text { Shoreline Impacts }\end{array}$ & $\begin{array}{l}85 \\
95 \\
95 \\
90\end{array}$ & & $\begin{array}{l}\text { REACH } \\
\text { EUNCTIONAL } \\
\text { INDEX }\end{array}$ \\
\hline $\begin{array}{l}\text { STRUCTURE } \\
\text { PROTECTION }\end{array}$ & $\begin{array}{l}\text { Nearby Structures } \\
\text {-Toe Erosion } \\
\text { +Trunk Protection }\end{array}$ & $\begin{array}{l}75 \\
70\end{array}$ & Natch & 75 \\
\hline $\begin{array}{l}\text { OTHER } \\
\text { EUNCTIONS }\end{array}$ & $\begin{array}{l}\text { Public Access } \\
\text { Recreational Use } \\
\text { Environmental Effect } \\
\text { Aids to Navigation }\end{array}$ & & & \\
\hline
\end{tabular}




\begin{tabular}{|c|c|c|c|c|}
\hline Date: 20 December 1996 & $\begin{array}{l}\text { INDEX CCMPU } \\
\text { Databas }\end{array}$ & ITION SHEET PE & ER REACH & ב00000 \\
\hline Project:ANTONIO RIVER & Structure:: & DRTH JETTY & Reach:NJ3B & \\
\hline Location: Antonio River & District: & strict 1 & Division: & \\
\hline Part A: Structure Condition & Surmary & Inspect & tion Start Date: & $05 / 27 / 1990$ \\
\hline STRUCTURE DEFICIENCY & CREST/CAP & SEASIDE/HEAD & CHANNEL/HARBOR & \\
\hline $\begin{array}{l}\text { Breach/Loss of Crest Elev. } \\
\text { Core Exposure/Loss } \\
\text { Armor Loss } \\
\text { Armor Contact/Interlock } \\
\text { Armor Quality Defects } \\
\text { Slope Defects }\end{array}$ & $\begin{array}{r}100 \\
100 \\
55 \\
85 \\
80\end{array}$ & $\begin{array}{r}100 \\
85 \\
60 \\
60 \\
45\end{array}$ & $\begin{array}{l}100 \\
100 \\
100 \\
100 \\
100\end{array}$ & $\begin{array}{l}\text { REACH } \\
\text { STRUCTURAL } \\
\text { INDEX }\end{array}$ \\
\hline STRUCTURAI INDEX & 67 & 56 & 100 & \\
\hline
\end{tabular}

Are there functional deficiencies which are NoT

related to structural defects? (YES NO) = NO

Is there risk of further major loss of function

within the next budget cycle?
(YES NO) $=$ NO

(ratings not included in CI calculation aze marked with an *)

Part B: Functional Rating Summary

\begin{tabular}{|c|c|c|c|c|}
\hline \multicolumn{2}{|c|}{ EUNCTION } & \multirow{2}{*}{$\begin{array}{c}\text { RA:ING } \\
85 \\
35 \\
85 \\
75\end{array}$} & \multirow[t]{2}{*}{$\begin{array}{c}\text { RECOMMENDED } \\
\text { ACTION }\end{array}$} & \\
\hline $\begin{array}{l}\text { HARBOR } \\
\text { AREA }\end{array}$ & $\begin{array}{l}\text { Harbor Use } \\
\text { a.Moored Vessels } \\
\text { b.Harbor Structure } \\
\text { c.other Eacilities }\end{array}$ & & & \\
\hline $\begin{array}{l}\text { NAVIGATION } \\
\text { C:IANNEL }\end{array}$ & $\begin{array}{l}\text { Entrance Use } \\
\text { Channel }\end{array}$ & $\begin{array}{l}90 \\
90\end{array}$ & & \\
\hline $\begin{array}{l}\text { SइDIMENT } \\
\text { MANAGEMENT }\end{array}$ & $\begin{array}{l}\text { Ebb Shoal } \\
\text { Elood Shoal } \\
\text { Harbor Shoal } \\
\text { Shoreline Impacts }\end{array}$ & $\begin{array}{l}85 \\
95 \\
95 \\
90\end{array}$ & & $\begin{array}{l}\text { REACH } \\
\text { EUNCTIONAL } \\
\text { INDEX }\end{array}$ \\
\hline $\begin{array}{l}\text { STRUCTURE } \\
\text { EROTECTION }\end{array}$ & $\begin{array}{l}\text { Nearby Structures } \\
\text { *Toe Erosion } \\
\text { *Trunk Protection }\end{array}$ & $\begin{array}{l}75 \\
70\end{array}$ & Watch & 75 \\
\hline $\begin{array}{l}\text { CTHER } \\
\text { EUNCTIONS }\end{array}$ & $\begin{array}{l}\text { Public Access } \\
\text { Recreational Use } \\
\text { Enviconmental Effect } \\
\text { Aids to Navigation }\end{array}$ & & & \\
\hline
\end{tabular}




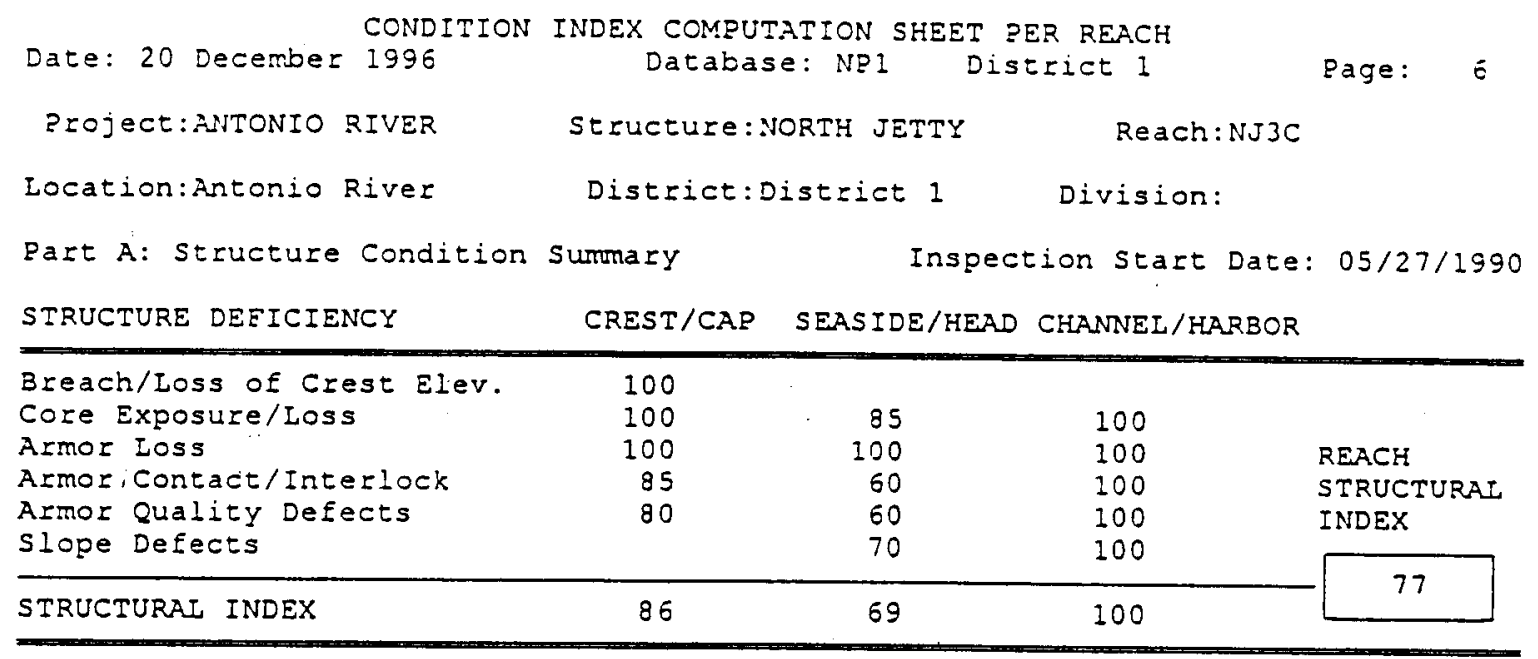

Are there functional deficiencies which are Nom related to structural defects?

$($ YES NO $)=$ NO

Is there risk of further major loss of function within the next budget eycle?

$($ YES NO $)=$ NO

(ratings not included in CI calculation are marked with an *)

Past B: Eunctional Rating Sumary

\begin{tabular}{|c|c|c|c|c|}
\hline \multicolumn{2}{|c|}{ EUNCTION } & \multicolumn{2}{|r|}{$\begin{array}{c}\text { RECOMMENDED } \\
\text { ACTION }\end{array}$} & \\
\hline $\begin{array}{l}\text { HARBOR } \\
\text { AREA }\end{array}$ & $\begin{array}{l}\text { Harbor Use } \\
\text { a.Moored Vessels } \\
\text { b.Harbor Structure } \\
\text { c.Other Eacilities }\end{array}$ & $\begin{array}{l}85 \\
85 \\
85 \\
75\end{array}$ & Watch & \\
\hline $\begin{array}{l}\text { NAVIGATION } \\
\text { CHANNEL }\end{array}$ & $\begin{array}{l}\text { Entrance Use } \\
\text { Channel }\end{array}$ & $\begin{array}{l}90 \\
90\end{array}$ & & \\
\hline $\begin{array}{l}\text { SEDIMENT } \\
\text { MANAGEMENT }\end{array}$ & $\begin{array}{l}\text { Ebb Shoal } \\
\text { Flood Shoal } \\
\text { Harbor Shoal } \\
\text { Shoreline Impacts }\end{array}$ & $\begin{array}{l}85 \\
95 \\
95 \\
90\end{array}$ & . & $\begin{array}{l}\text { REACH } \\
\text { EUNCTIONAL } \\
\text { INDEX }\end{array}$ \\
\hline $\begin{array}{l}\text { STRUCTURE } \\
\text { PROTECTION }\end{array}$ & $\begin{array}{l}\text { Nearby Structures } \\
\text { *Toe Erosion } \\
\text { *Trunk Protection }\end{array}$ & $\begin{array}{l}75 \\
70\end{array}$ & Watch & 75 \\
\hline $\begin{array}{l}\text { OTHER } \\
\text { EUNCTIONS }\end{array}$ & $\begin{array}{l}\text { Public Access } \\
\text { Recreational Use } \\
\text { Environmental Effect } \\
\text { Aids to Navigation }\end{array}$ & & & \\
\hline
\end{tabular}




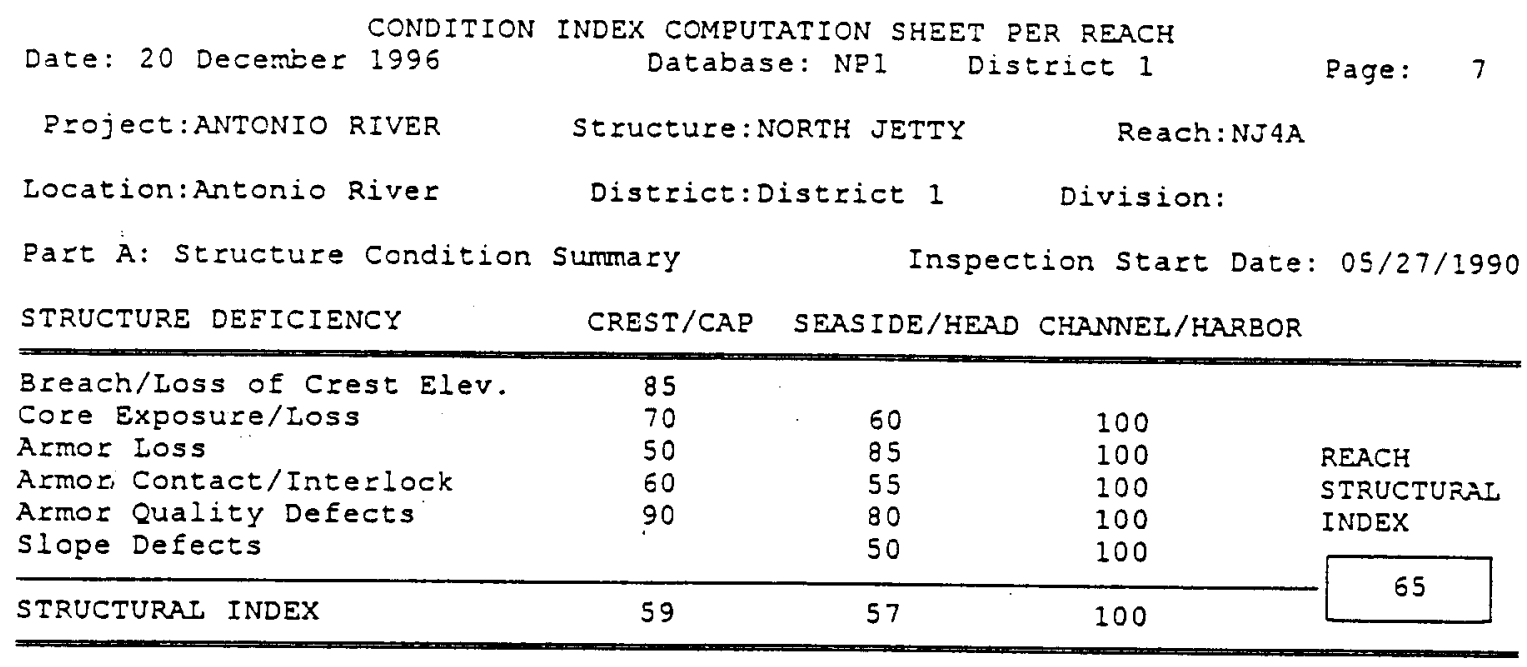

Are there functional deficiencies which are NOT related to structural defects?
(YES NO) $=$ NO

Is there'risk of Eurther major loss of function within the next budget cycle? (YES NO) = NO

(ratings not included in CI calculation are marked with an +)

Part B: Functional Rating Summary

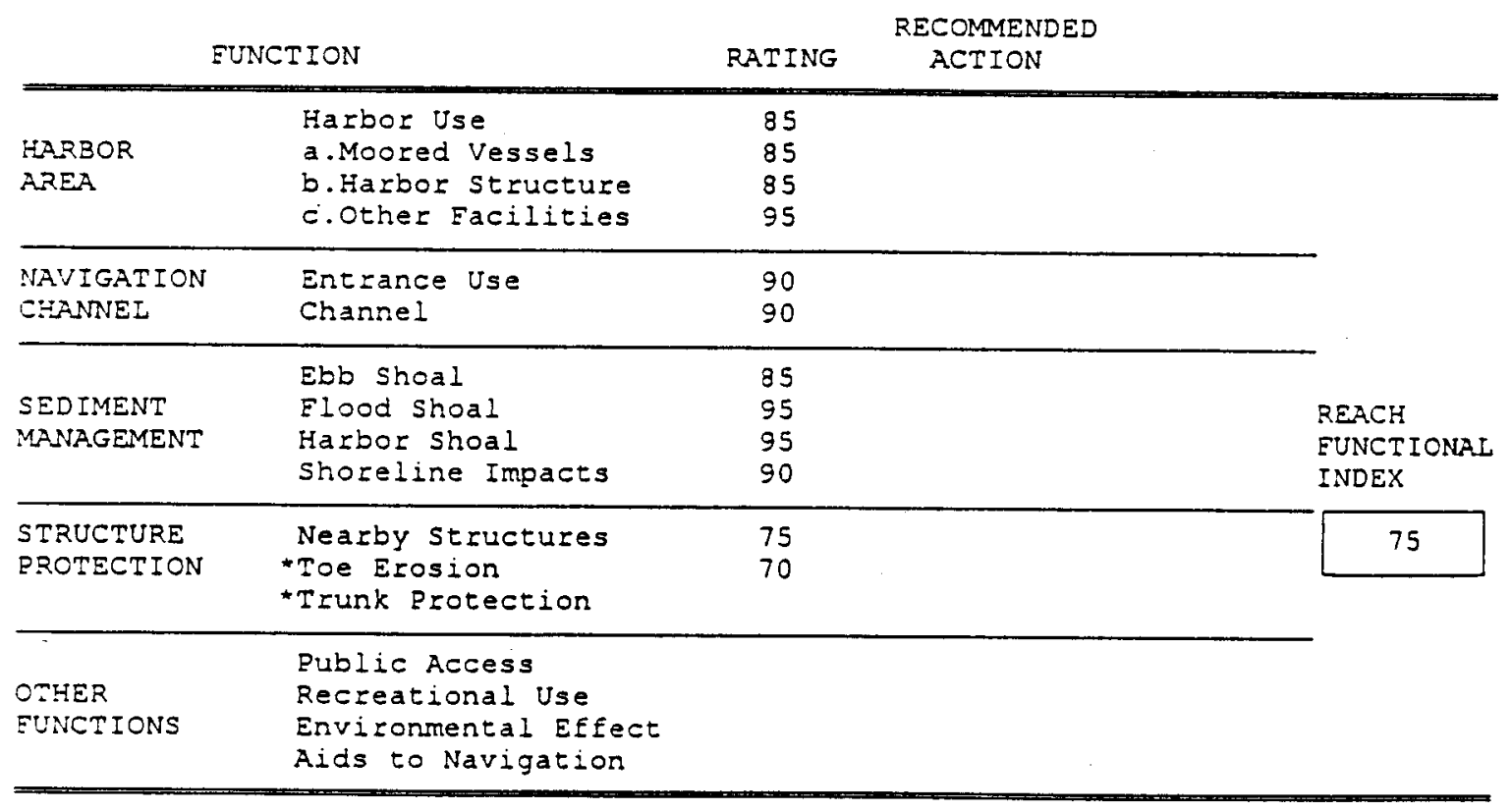




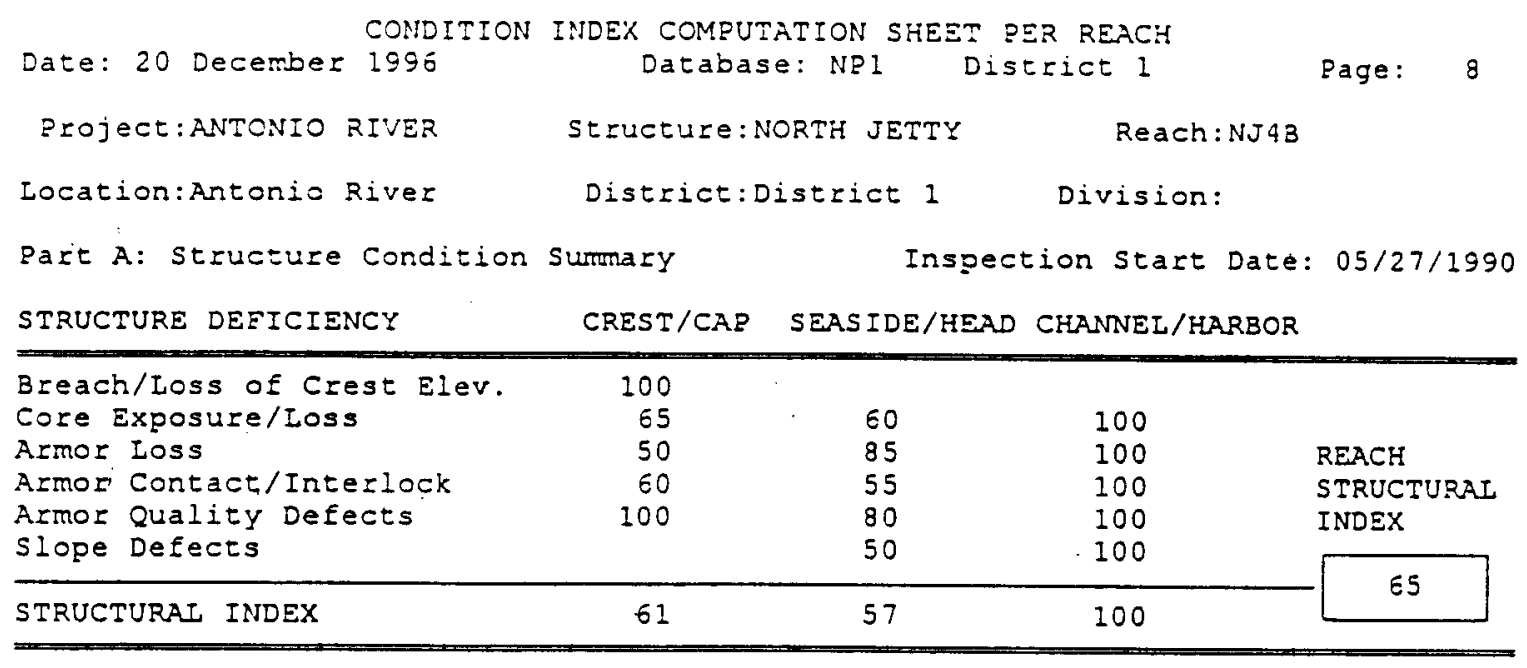

Are there functional deficiencies which are NOT related to structural defects? (YES NO) = NO

Is there risk of further major loss of function within the next budget cycle? (YES NO) = NO

(ratings not included in CI calculation are marked with an *)

Part B: Functional Rating Summary

\begin{tabular}{|c|c|c|c|}
\hline & CIION & $\begin{array}{cc}\text { RECCMMENDED } \\
\text { RATING } \\
\text { ACTION }\end{array}$ & \\
\hline $\begin{array}{l}\text { HARBOR } \\
\text { AREA }\end{array}$ & $\begin{array}{l}\text { Harbor Use } \\
\text { a.Moored Vessels } \\
\text { b.Harbor Structure } \\
\text { c.Other Facilities }\end{array}$ & $\begin{array}{l}85 \\
85 \\
85 \\
95\end{array}$ & \multirow[b]{3}{*}{$\begin{array}{l}\text { REACH } \\
\text { EUNCTIONAI } \\
\text { INDEX }\end{array}$} \\
\hline $\begin{array}{l}\text { NAVIGATION } \\
\text { CHANNEI }\end{array}$ & $\begin{array}{l}\text { Entrance Use } \\
\text { Channel }\end{array}$ & $\begin{array}{l}90 \\
90\end{array}$ & \\
\hline $\begin{array}{l}\text { SEDIMENT } \\
\text { MANAGEMENT }\end{array}$ & $\begin{array}{l}\text { Ebb Shoal } \\
\text { Elood Shoal } \\
\text { Harbor Shoal } \\
\text { Shoreline Impacts }\end{array}$ & $\begin{array}{l}85 \\
95 \\
95 \\
90\end{array}$ & \\
\hline $\begin{array}{l}\text { STRUCTURE } \\
\text { PROTECTION }\end{array}$ & $\begin{array}{l}\text { Nearby Structures } \\
\text { - Toe Erosion } \\
\text { +Trunk Protection }\end{array}$ & $\begin{array}{l}75 \\
70\end{array}$ & 75 \\
\hline $\begin{array}{l}\text { OTHER } \\
\text { EUNCTIONS }\end{array}$ & $\begin{array}{l}\text { Public Access } \\
\text { Recreational Use } \\
\text { Environmental Effect } \\
\text { Aids to Navigation }\end{array}$ & & \\
\hline
\end{tabular}




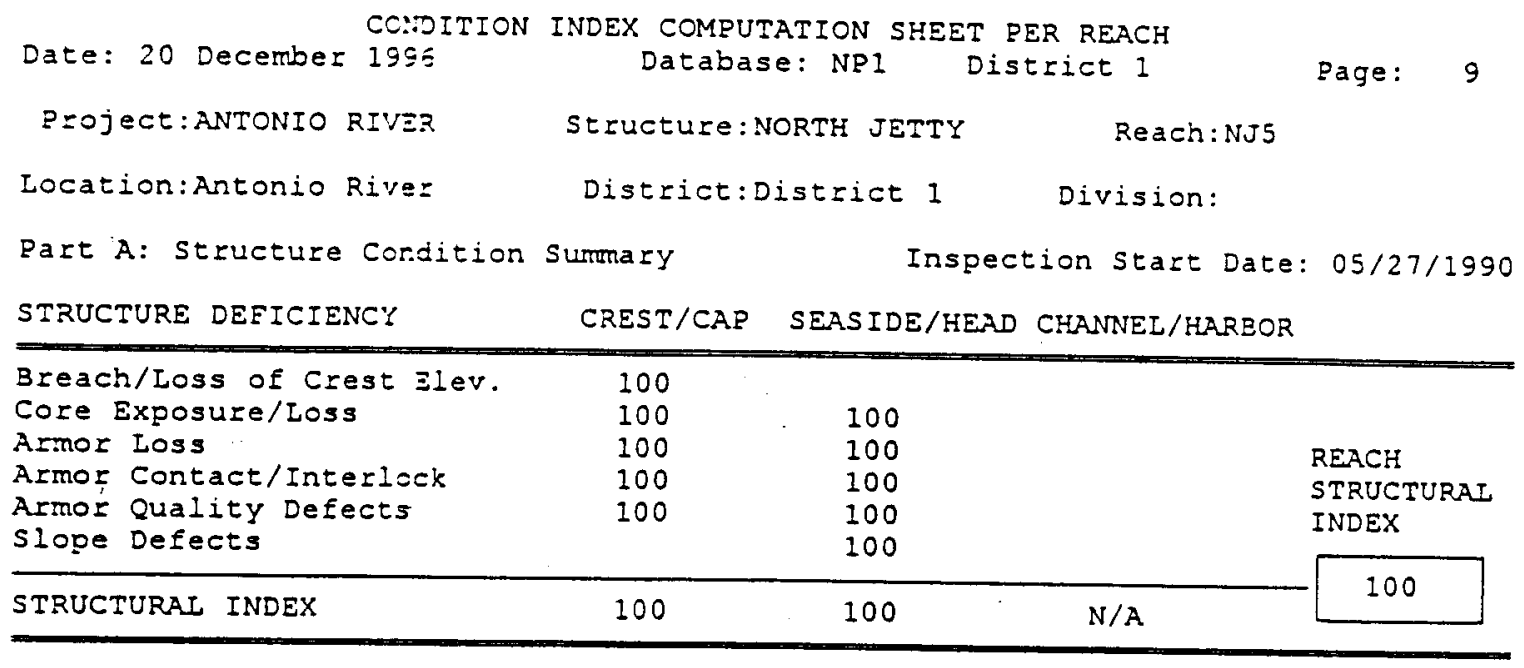

Are there functional seficiencies which are NOT $\begin{array}{ll}\text { related to structural defects? } & \text { (YES NO) }=\text { NO }\end{array}$

Is there risk of furtier major loss of function within the next budge: cycle? (YES NO) = NO

(ratings not included in CI calculation are marked with an *)

Part B: Functional Razing Summary

\begin{tabular}{|c|c|c|c|c|}
\hline \multicolumn{2}{|c|}{ EUNCTION } & \multicolumn{2}{|c|}{$\begin{array}{c}\text { RECOMMENDED } \\
\text { ACTION }\end{array}$} & \\
\hline $\begin{array}{l}\text { FARBOR } \\
\text { A_REA }\end{array}$ & $\begin{array}{l}\text { Harbor Use } \\
\text { a.Moored Vessels } \\
\text { b.Harbor Structure } \\
\text { c.othez Facilities }\end{array}$ & & & \\
\hline $\begin{array}{l}\text { NAVIGATION } \\
\text { CHANNEL }\end{array}$ & $\begin{array}{l}\text { Entranze Use } \\
\text { Channe? }\end{array}$ & & & \\
\hline $\begin{array}{l}\text { SEDIMENT } \\
\text { MENA.GEMENT }\end{array}$ & $\begin{array}{l}\text { Ebb Shcal } \\
\text { Flood Shoal } \\
\text { Harbor Shoal } \\
\text { Shoreline Impacts }\end{array}$ & 100 & & $\begin{array}{l}\text { REACH } \\
\text { FUNCTIONAL } \\
\text { INDEX }\end{array}$ \\
\hline $\begin{array}{l}\text { STRUCTURE } \\
\text { PROTECTION }\end{array}$ & $\begin{array}{l}\text { Nearby structures } \\
\text { *Toe Erssion } \\
\text { *Trunk Szotection }\end{array}$ & $\begin{array}{l}100 \\
100\end{array}$ & & 100 \\
\hline $\begin{array}{l}\text { OTHER } \\
\text { EUNCTIONS }\end{array}$ & $\begin{array}{l}\text { Public Access } \\
\text { Recreational Use } \\
\text { Envirormental Effect } \\
\text { Aids to Navigation }\end{array}$ & & & \\
\hline
\end{tabular}




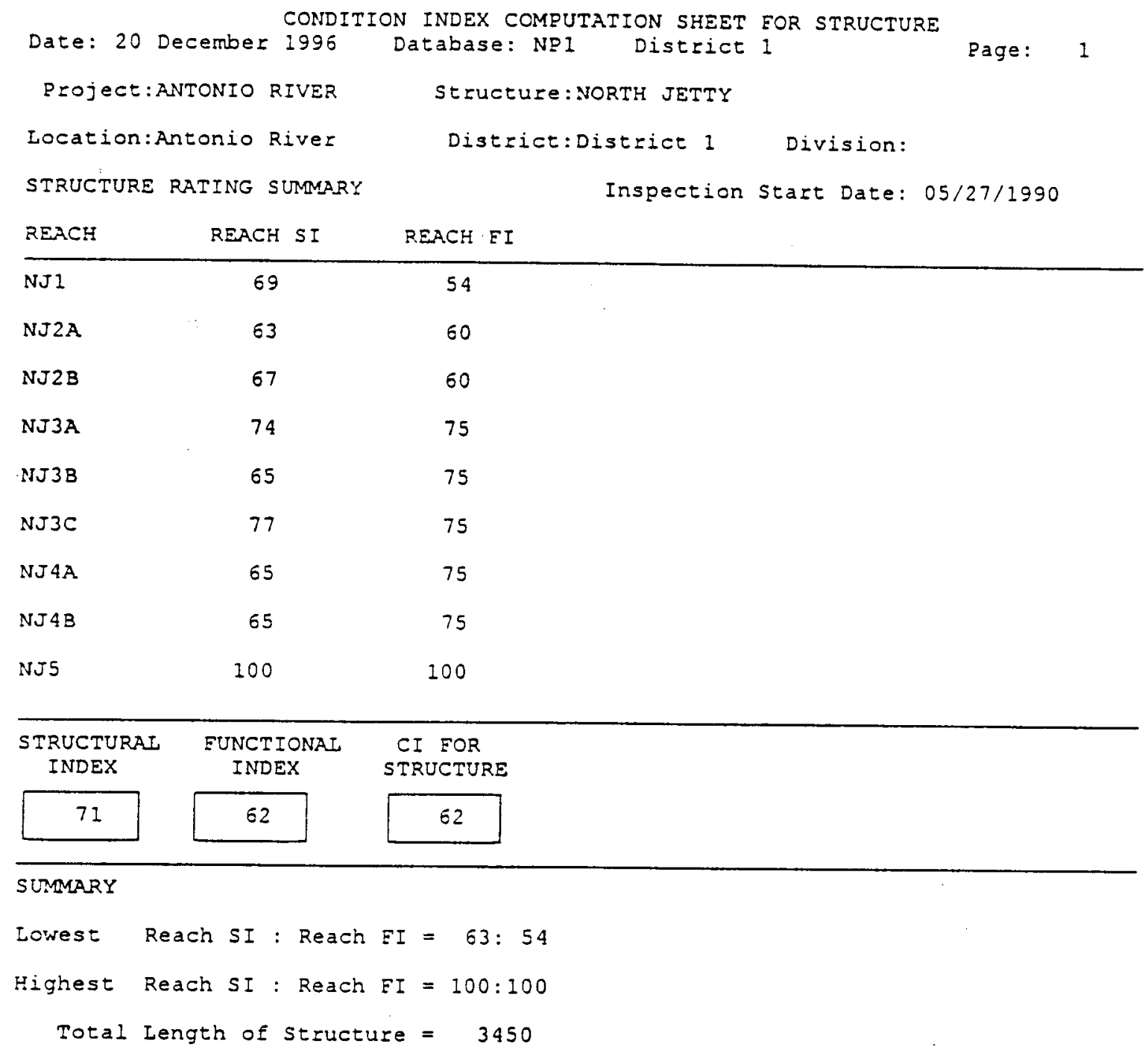




\section{Historical Index Rating Summary}




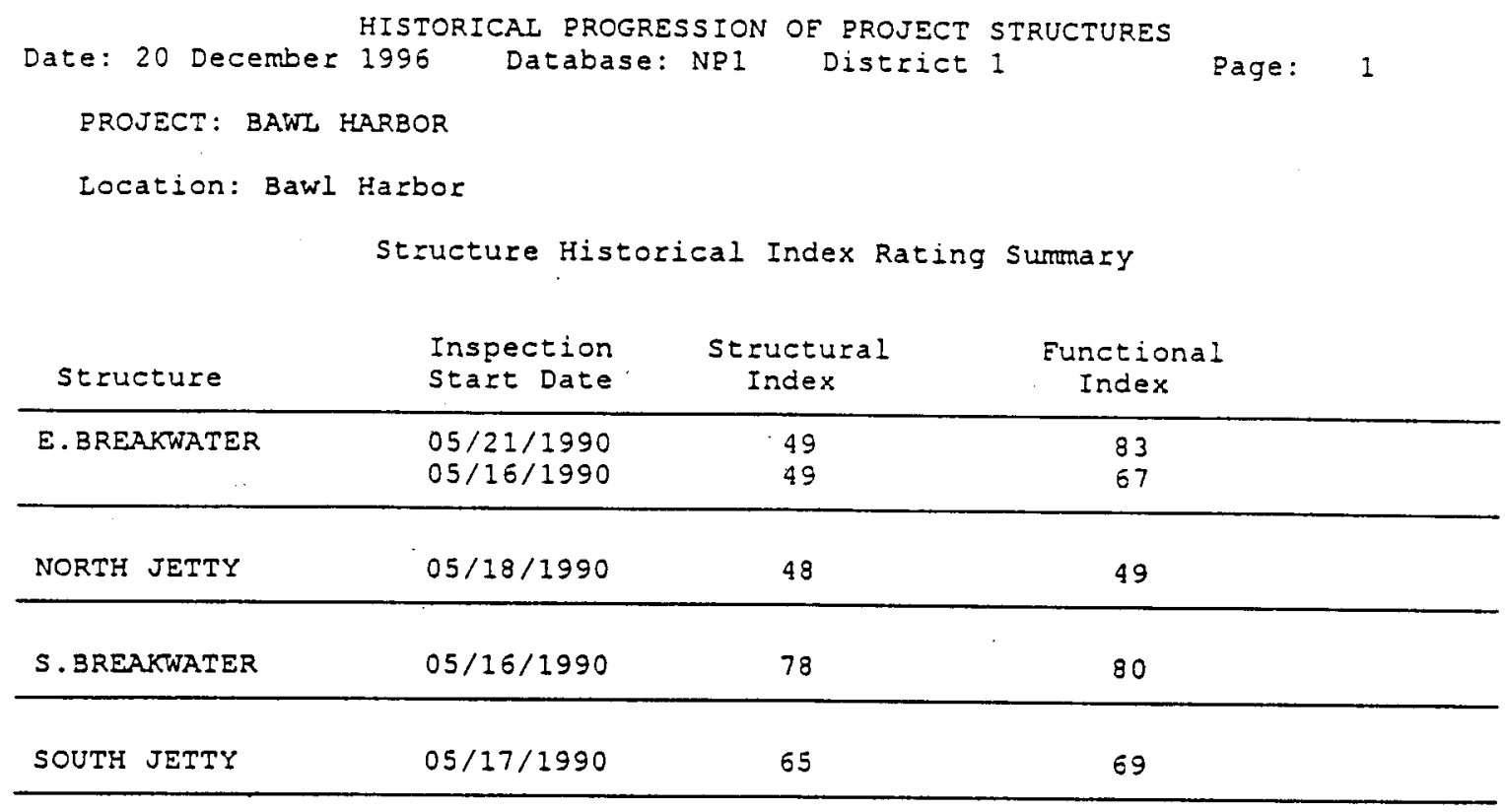


Comment Report: Reach 
Date: 20 December 1996

Project: ANTONIO RIVER

Location:Antonio River
COMMENT REPORT PER REACH

Database: NPI District 1 Page: 1

Structure:NORTH JETTY Reach:NJI

District:District 1 Division:

Inspection Start Date: 05/27/1990

Part A: Structural Comments

CATEGORY STRUCTURE DEEICIENCY COMENTS

CREST/CAP Breach/Loss of Crest Elev. None

Core Exposure/Loss None

Armor Loss None

Armor Contact/Interlock None

Armor Quality Defects Many of these problems have compounded

each other.

\begin{tabular}{lll}
\hline SEASIDE/ & Core Exposure/Loss & None \\
HEAD & Nomor Loss & None \\
& Armor Contact/Interlock & None \\
& Armor Quality Defects & None \\
& Slope Defects & None \\
\hline CHANNEL/ Core Exposure/Loss & None \\
HARBOR & Armor Loss & None \\
& Armor Contact/Interlock & None \\
& Armor Quality Defects & None \\
& Slope Defects &
\end{tabular}

Part B: Functional Comments

EUNCTION DEFICIENCY COMMENTS

$\begin{array}{lll}\text { HARBOR AREA } & \text { Harbor Use } & \text { None } \\ & \text { a.Moored Vessels } & \text { None } \\ \text { b.Harbor Structure } & \text { None } \\ \text { c.Other Eacilities } & \text { None }\end{array}$

NAVIGATION Entzance Use None

\begin{tabular}{lll}
\hline SEDIMENT & Ebb Shoal & None \\
MANAGEMENT & Flood Shoal & There are two potentially hazardous shoals \\
& which will become a problem if not taken care \\
& of.
\end{tabular}




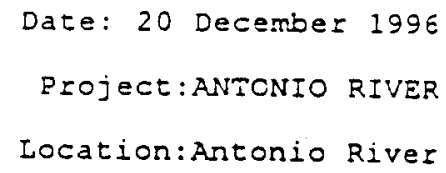

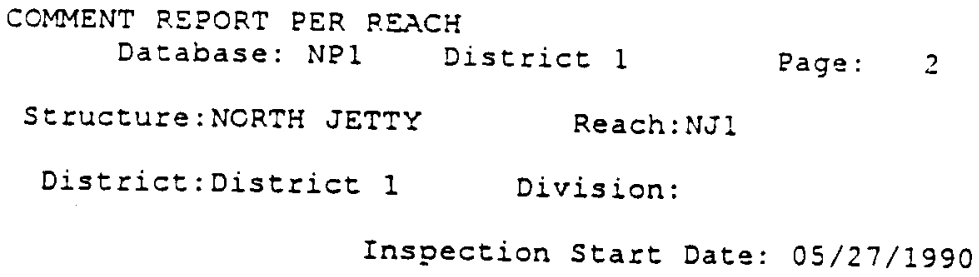

\begin{tabular}{|c|c|c|}
\hline & $\begin{array}{l}\text { Harbor Shoal } \\
\text { Shoreline Impacts }\end{array}$ & $\begin{array}{l}\text { None } \\
\text { The amount of sediment protecting the shore is } \\
\text { not enough to prevent a flood. }\end{array}$ \\
\hline $\begin{array}{l}\text { STRUCTURE } \\
\text { EROTECTION }\end{array}$ & $\begin{array}{l}\text { Nearby Structures } \\
\text { Toe Erosion } \\
\text { Trunk Protection }\end{array}$ & $\begin{array}{l}\text { None } \\
\text { Minor scour has occurred at the toe, but there } \\
\text { is potential for more scour if the shoreline } \\
\text { sediment is not replaced. } \\
\text { The amount of sediment potecting the shore is } \\
\text { not enough to prevent a flood. }\end{array}$ \\
\hline $\begin{array}{l}\text { OTHER } \\
\text { FUNCTIONS }\end{array}$ & $\begin{array}{l}\text { Public Access } \\
\text { Recreational Use } \\
\text { Environmental Effect } \\
\text { Aids to Navigation }\end{array}$ & $\begin{array}{l}\text { None } \\
\text { None } \\
\text { None } \\
\text { None }\end{array}$ \\
\hline $\begin{array}{l}\text { Functional } \\
\text { related to } \\
\text { Risk of furt } \\
\text { loss within }\end{array}$ & $\begin{array}{l}\text { deficiencies NoT } \\
\text { structural defects? } \\
\text { ther major functional } \\
\text { next budget cycle? }\end{array}$ & $\begin{array}{l}\text { None } \\
\text { None }\end{array}$ \\
\hline
\end{tabular}




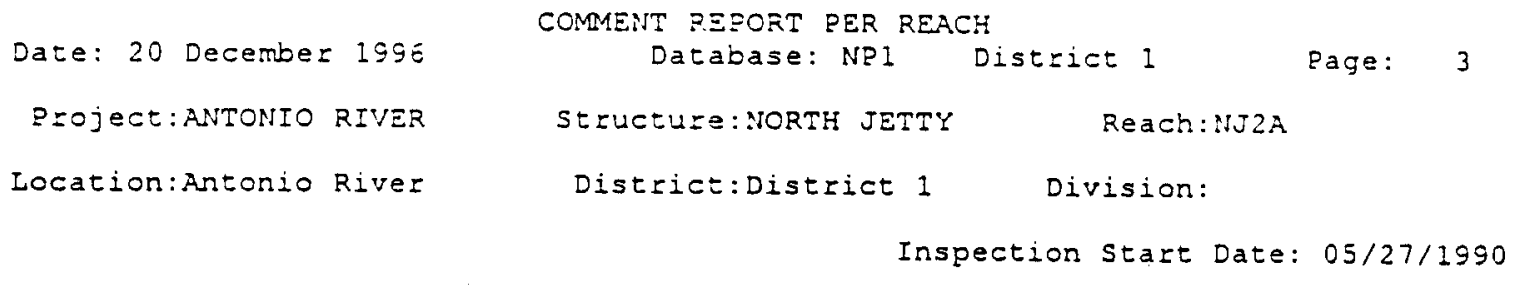

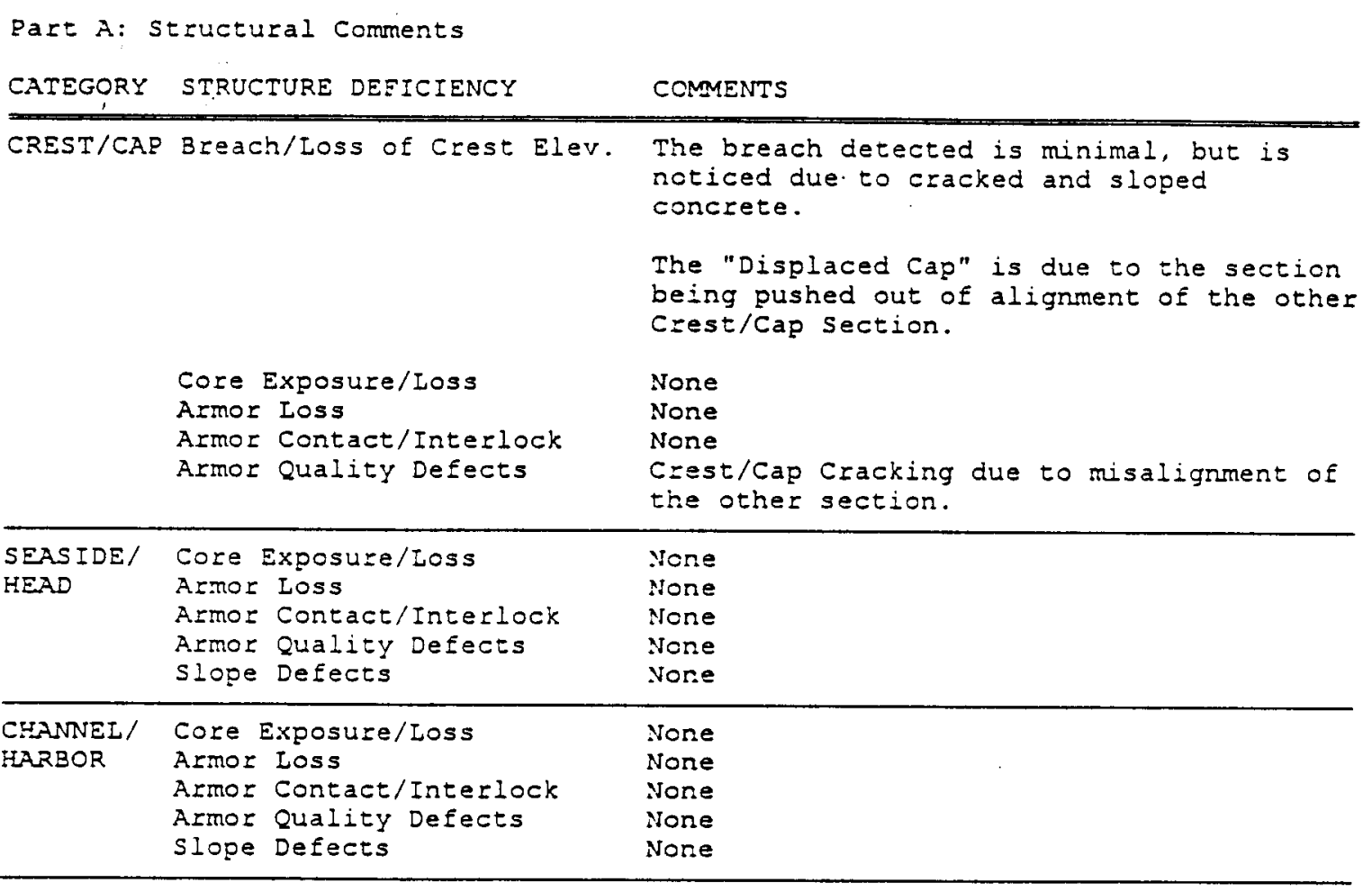

Part B: Functional Comments

\begin{tabular}{|c|c|c|}
\hline EUNCTION & DEEICIENCY & COMMENTS \\
\hline HARBOR AREA & $\begin{array}{l}\text { Harbor Use } \\
\text { a.Moored Vessels } \\
\text { b.Harbor Structure } \\
\text { c.Other Eacilities }\end{array}$ & $\begin{array}{l}\text { None } \\
\text { None } \\
\text { Minct erosion at scattered locations. } \\
\text { None }\end{array}$ \\
\hline
\end{tabular}

NAVIGATION Entrance Use None




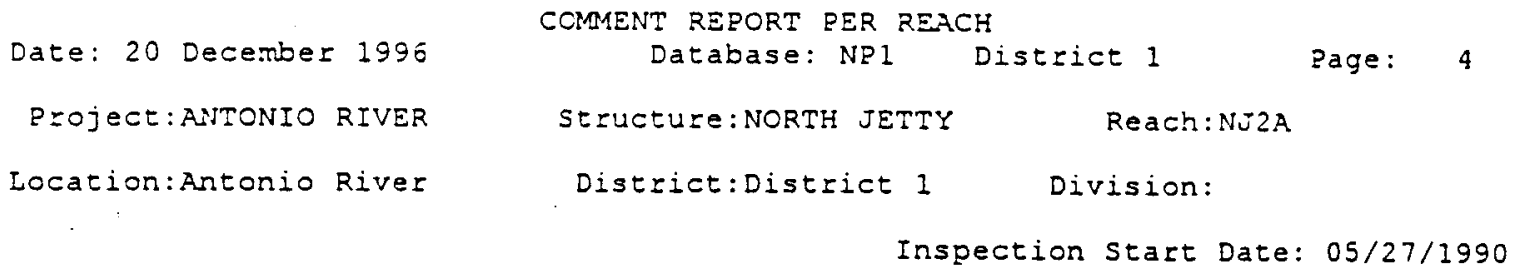

\begin{tabular}{|c|c|c|}
\hline CHANNEI & Channel & None \\
\hline $\begin{array}{l}\text { SEDIMENT } \\
\text { MANAGEMENT }\end{array}$ & $\begin{array}{l}\text { Ebb Shoal } \\
\text { Elood Shoal } \\
\text { Harbor shoal } \\
\text { Shoreline Impacts }\end{array}$ & $\begin{array}{l}\text { None } \\
\text { None } \\
\text { There is no problem along the channel, } \\
\text { however, there has been sediment movement from } \\
\text { the channel, and this has affected the harbor } \\
\text { area. } \\
\text { None }\end{array}$ \\
\hline $\begin{array}{l}\text { STRUCTURE } \\
\text { PROTECTION }\end{array}$ & $\begin{array}{l}\text { Nearby structures } \\
\text { Toe Erosion } \\
\text { Trunk Protection }\end{array}$ & $\begin{array}{l}\text { None } \\
\text { None } \\
\text { None }\end{array}$ \\
\hline $\begin{array}{l}\text { OTHER } \\
\text { EUNCTIONS }\end{array}$ & $\begin{array}{l}\text { Rublic Access } \\
\text { Recreational Use } \\
\text { Environmental Effect } \\
\text { Aids to Navigation }\end{array}$ & $\begin{array}{l}\text { The public should be aware of the cracks on } \\
\text { the side walks. } \\
\text { None } \\
\text { None } \\
\text { None }\end{array}$ \\
\hline \multicolumn{2}{|c|}{$\begin{array}{l}\text { Eunctional deficiencies NOT } \\
\text { reiated to structural defects? }\end{array}$} & None \\
\hline \multicolumn{2}{|c|}{$\begin{array}{l}\text { Risk of further major functional } \\
\text { loss within next budget cycle? }\end{array}$} & None \\
\hline
\end{tabular}




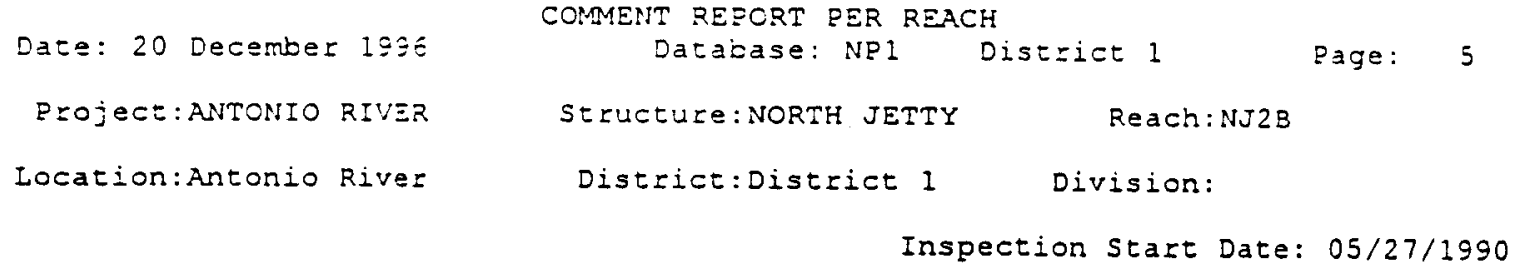

Part A: Structural Coments

\begin{tabular}{lll} 
CATEGORY STRUCTURE DEFICIENCY & COMMENTS \\
\hline CREST/CAP & Breach/Loss of Crest Elev. & None \\
& Core Exposure/Loss & None \\
& Armor Loss & None \\
& Armor Contact/Interlock & None \\
& Armor Quality Defects & None \\
\hline SEASIDE/ & Core Exposure/Loss & None \\
HEAD & Armor Loss & None \\
& Armor Contact/Interlock & None \\
& Armor Qualizy Defects & None \\
& Slope Defects & None \\
\hline CHANNEL/ Core Exposuze/Loss & None \\
HARBOR & Armor Loss & None \\
& Armor Contact/Interlock & None \\
Armor Qualizy Defects & None \\
& Slope Defecis & None \\
\hline
\end{tabular}

Part 3: Functional Coments

\begin{tabular}{|c|c|c|}
\hline EUNCTION & DEEICIENCY & COMMENTS \\
\hline FARBCR AREA & $\begin{array}{l}\text { Harbor Use } \\
\text { a.Moored Vessels } \\
\text { b.Harbor Structure } \\
\text { c.other Dacilities }\end{array}$ & $\begin{array}{l}\text { None } \\
\text { None } \\
\text { Minor erosion at scattered locations. } \\
\text { None }\end{array}$ \\
\hline $\begin{array}{l}\text { NAVIGATION } \\
\text { CHLANNEL }\end{array}$ & $\begin{array}{l}\text { Entrance Use } \\
\text { Channel }\end{array}$ & $\begin{array}{l}\text { None } \\
\text { None }\end{array}$ \\
\hline $\begin{array}{l}\text { SEDIMENT } \\
\text { MANAGEMENT }\end{array}$ & $\begin{array}{l}\text { Ebb Shoal } \\
\text { Elood shoal } \\
\text { Harbor shoal }\end{array}$ & $\begin{array}{l}\text { None } \\
\text { None } \\
\text { There is no problem along the channel, } \\
\text { however, there has been sediment movement from } \\
\text { the channel, and this has affected the harbor }\end{array}$ \\
\hline
\end{tabular}




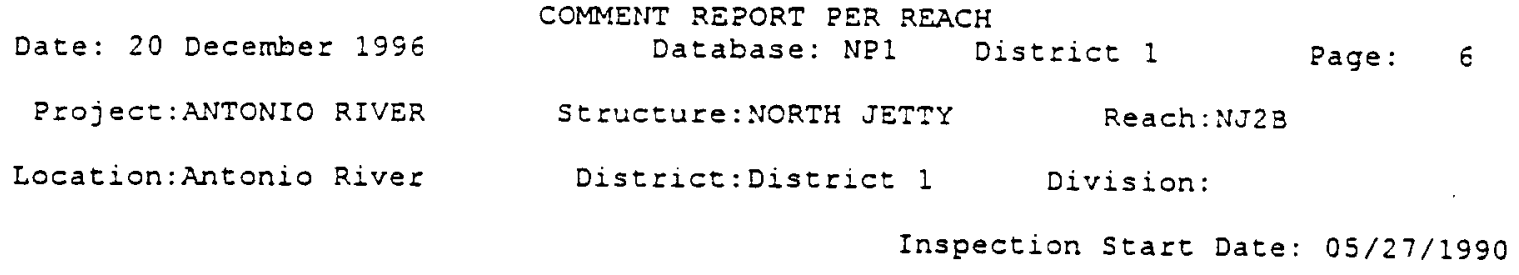

\begin{tabular}{|c|c|c|}
\hline & Shoreline Impacts & $\begin{array}{l}\text { area } \\
\text { None }\end{array}$ \\
\hline $\begin{array}{l}\text { STRUCTURE } \\
\text { PROTECTION }\end{array}$ & $\begin{array}{l}\text { Nearby Structures } \\
\text { Toe Erosion } \\
\text { Trunk Protection }\end{array}$ & $\begin{array}{l}\text { None } \\
\text { None } \\
\text { None }\end{array}$ \\
\hline $\begin{array}{l}\text { OTHER } \\
\text { EUNCTIONS }\end{array}$ & $\begin{array}{l}\text { Public Access } \\
\text { Recreational Use } \\
\text { Environmental Effect } \\
\text { Aids to Navigation }\end{array}$ & $\begin{array}{l}\text { None } \\
\text { None } \\
\text { None } \\
\text { None }\end{array}$ \\
\hline \multicolumn{2}{|c|}{$\begin{array}{l}\text { Functional deficiencies NOT } \\
\text { related to structural defects? }\end{array}$} & None \\
\hline \multicolumn{2}{|c|}{$\begin{array}{l}\text { Risk of Eurther major functional } \\
\text { loss within next budget cycle? }\end{array}$} & None \\
\hline
\end{tabular}


Date: 20 December 1996

Project:ANTONIO RIVER

Location:Antonio River
COMMENT REPORT PER REACH

$$
\text { Database: NP1 District } 1 \quad \text { Page: } 7
$$

Structure:NORTH JETTY

Reach:NJ3A

District:District 1 Division:

Inspection Start Date: 05/27/1990

\begin{tabular}{lll} 
Part A: Structural Coments & \\
CATEGORY STRUCTURE DEFICIENCY & COMMENTS \\
\hline CREST/CAP Breach/Loss of Crest Elev. & None \\
& Core Exposure/Loss & None \\
& Armor Loss & None \\
& Armor Contact/Interlock & None \\
& Armor Quality Defects & None \\
\hline SEASIDE/ & Core Exposure/Loss & None \\
HEAD & Armor Loss & None \\
& Armor Contact/Interlock & None \\
& Armor Quality Defects & None \\
& Slope Defects & None \\
\hline CHANNEL/ Core Exposure/Loss & None \\
HARBOR & Armor Loss & None \\
& Armor Contact/Interlock & None \\
& Armor Quality Defects & None \\
& Slope Defects & None \\
\hline
\end{tabular}

Part B: Functional Comments

\begin{tabular}{lll} 
FUNCTION & DEEICIENCY & COMMENTS \\
\hline HARBOR AREA & $\begin{array}{ll}\text { Harbor Use } \\
\text { a.MOored Vessels }\end{array}$ & None \\
b.Harbor Structure & None \\
& c.Other Eacilities & Noticed a little toe scour. Problem may \\
& persist.
\end{tabular}

\begin{tabular}{|c|c|c|}
\hline $\begin{array}{l}\text { NAVIGATION } \\
\text { CHANNEL }\end{array}$ & $\begin{array}{l}\text { Entrance Use } \\
\text { Channel }\end{array}$ & $\begin{array}{l}\text { None } \\
\text { None }\end{array}$ \\
\hline $\begin{array}{l}\text { SEDIMENT } \\
\text { MANAGEMENT }\end{array}$ & $\begin{array}{l}\text { Ebb Shoal } \\
\text { Elood Shoal } \\
\text { Harbor shoal } \\
\text { Shoreline Impacts }\end{array}$ & $\begin{array}{l}\text { None } \\
\text { None } \\
\text { None } \\
\text { None }\end{array}$ \\
\hline
\end{tabular}




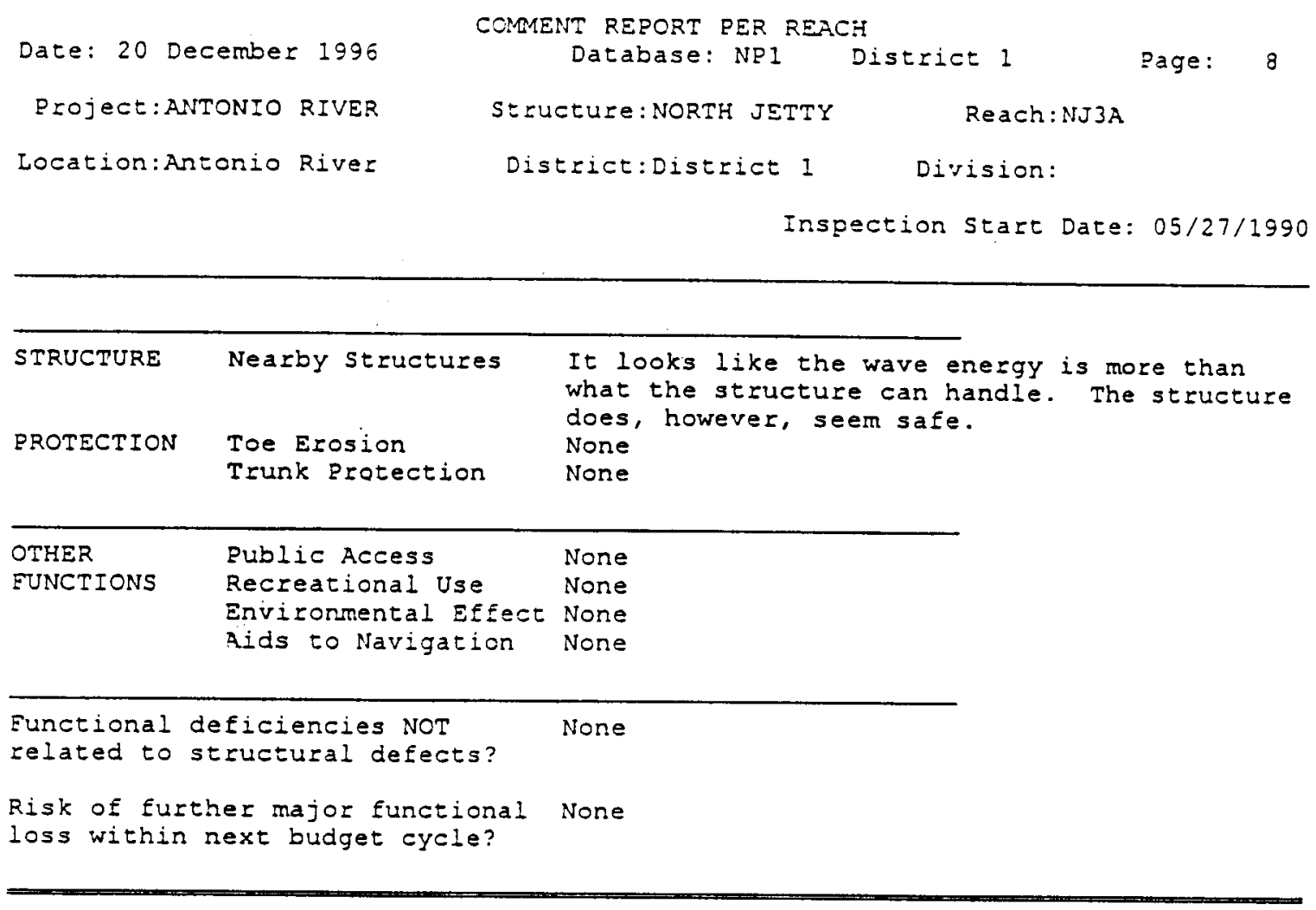




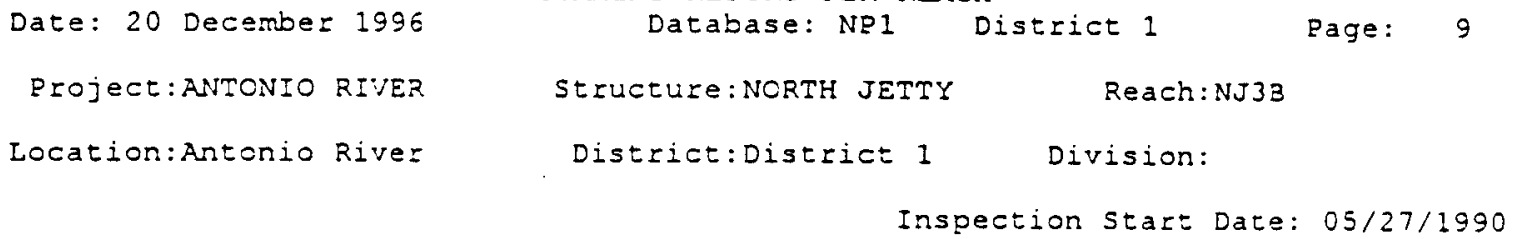

\begin{tabular}{lll} 
CATEGORY & STRUCTURE DEEICIENCY & COMENTS \\
\hline CREST/CAP & Breach/Loss of Crest Elev. & None \\
& Core Exposure/LOSs & None \\
& Armor Loss & None \\
& Armor Contact/Interlock & None \\
& Armor Quality Defects & None \\
\hline SEASIDE/ Core Exposure/Loss & None \\
HEAD & Armor Loss & None \\
& Armor Contact/Interlock & None \\
& Armor Quality Defects & None \\
& SLope Defects & None \\
\hline CHANNEL/ Core Exposuze/Loss & None \\
HARBOR & Armor Loss & None \\
& Armor Contact/Interlock & None \\
& Armor Quality Defects & None \\
& Slope Defects & None \\
\hline
\end{tabular}

Part B: Functional Coments

\begin{tabular}{|c|c|c|}
\hline FUNCTION & DEEICIENCY & COMMENTS \\
\hline FARBOR AREA & $\begin{array}{l}\text { Harbor Use } \\
\text { a.Moored Vessels } \\
\text { b.Harbor Structure } \\
\text { c.other Eacilities }\end{array}$ & $\begin{array}{l}\text { None } \\
\text { None } \\
\text { None } \\
\text { None }\end{array}$ \\
\hline $\begin{array}{l}\text { NAVIGATION } \\
\text { CHANNEL }\end{array}$ & $\begin{array}{l}\text { Entrance Use } \\
\text { Channel }\end{array}$ & $\begin{array}{l}\text { None } \\
\text { None }\end{array}$ \\
\hline $\begin{array}{l}\text { SEDIMENT } \\
\text { MANAGEMENT }\end{array}$ & $\begin{array}{l}\text { Ebb Shoal } \\
\text { Elood Shoal } \\
\text { Harbor shoal } \\
\text { Shoreline Impacts }\end{array}$ & $\begin{array}{l}\text { None } \\
\text { None } \\
\text { None } \\
\text { None }\end{array}$ \\
\hline
\end{tabular}




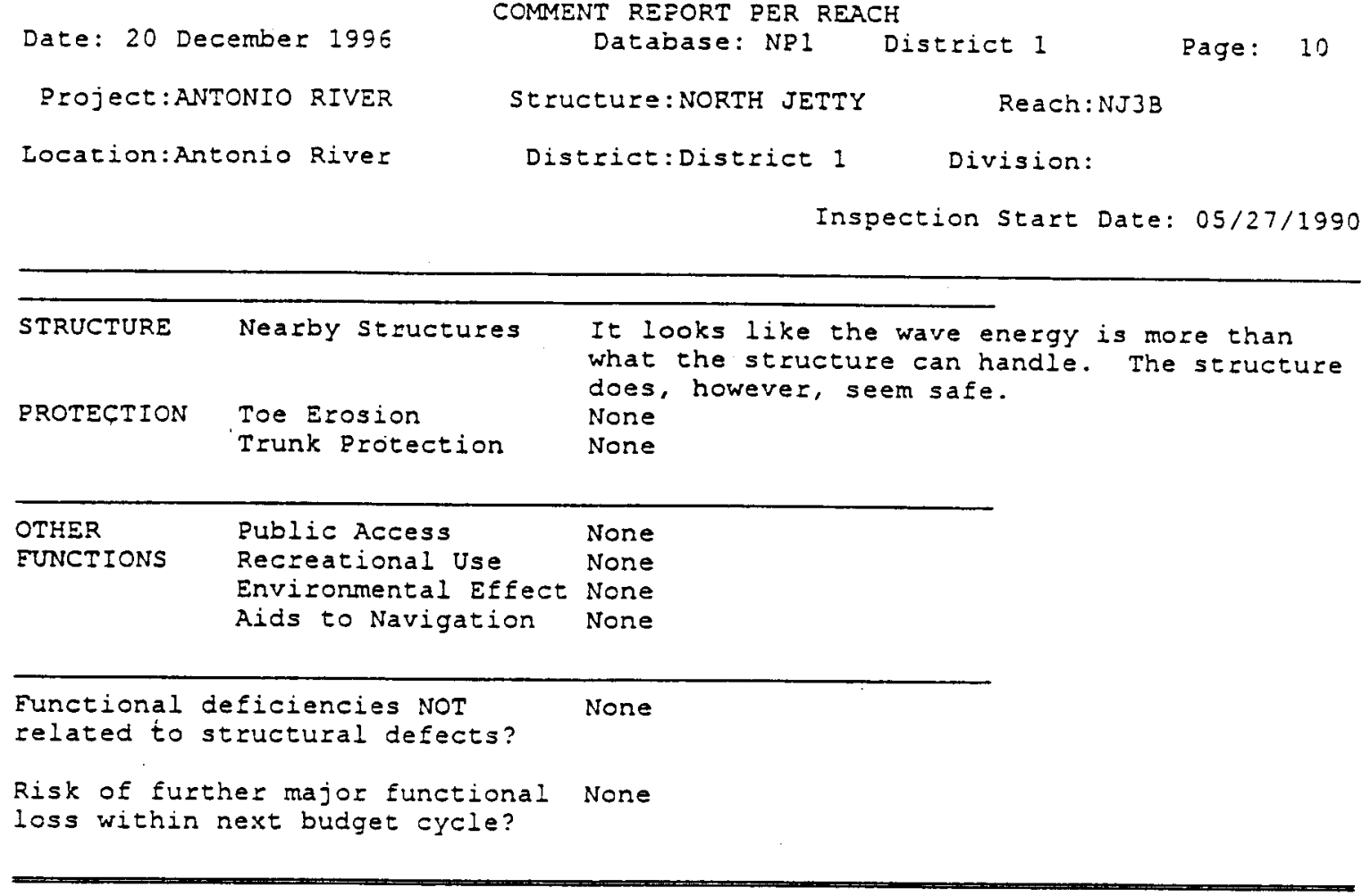




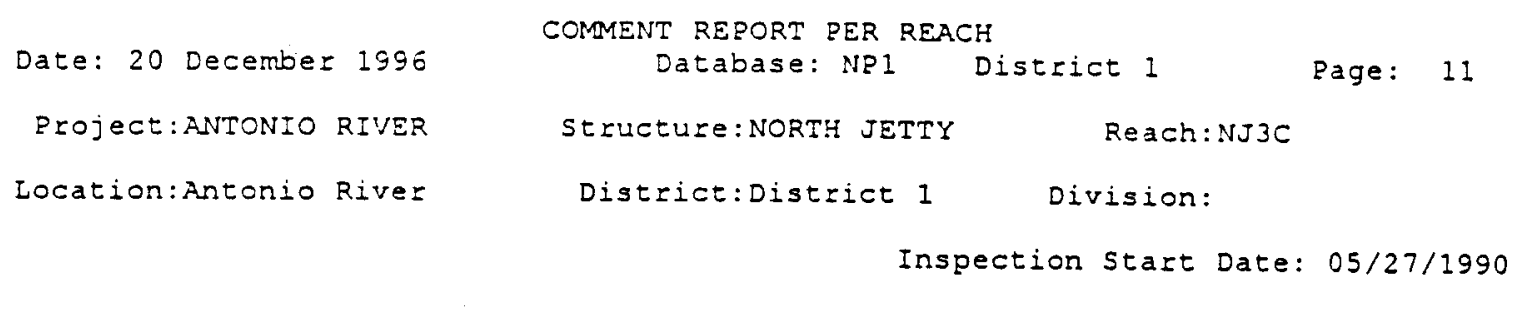

\begin{tabular}{|c|c|c|}
\hline CATEGORY & STRUCTURE DEEICIENCY & COMMENTS \\
\hline CREST/CAP & $\begin{array}{l}\text { Breach/Loss of Crest Elev. } \\
\text { Core Exposure/Loss } \\
\text { Armor Loss } \\
\text { Armor Contact/Interlock } \\
\text { Armor Quality Defects }\end{array}$ & $\begin{array}{l}\text { None } \\
\text { None } \\
\text { None } \\
\text { None } \\
\text { None }\end{array}$ \\
\hline $\begin{array}{l}\text { SEASIDE/ } \\
\text { HEAD }\end{array}$ & $\begin{array}{l}\text { Core Exposure/Loss } \\
\text { Armor Loss } \\
\text { Armor Contact/Interlock } \\
\text { Armor Quality Defects } \\
\text { Slope Defects }\end{array}$ & $\begin{array}{l}\text { None } \\
\text { None } \\
\text { None } \\
\text { None } \\
\text { None }\end{array}$ \\
\hline $\begin{array}{l}\text { CHANNEL / } \\
\text { HARBOR }\end{array}$ & $\begin{array}{l}\text { Core Exposure/Ioss } \\
\text { Armor Loss } \\
\text { Armor Contact/Interlock } \\
\text { Armor Quality Defects } \\
\text { Slope Defects }\end{array}$ & $\begin{array}{l}\text { None } \\
\text { None } \\
\text { None } \\
\text { None } \\
\text { None }\end{array}$ \\
\hline
\end{tabular}

Part B: Functional Comments

\begin{tabular}{lll} 
EUNCTION & DEFICIENCY & COMMENTS \\
\hline HARBOR AREA & $\begin{array}{l}\text { Harbor Use } \\
\text { a.Moored Vessels } \\
\text { b.Harbor Structure } \\
\text { C.Other Facilities }\end{array}$ & $\begin{array}{l}\text { None } \\
\text { None } \\
\text { Noticed a little toe scour. Problem may } \\
\end{array}$ \\
& & persist. \\
\hline NAVIGATION & Entrance Use & None \\
CHANNEI & Channel & None \\
& & \\
\hline SEDIMENT & Ebb Shoal & None \\
MANAGEMENT & Elood Shoal & None \\
& Harbor Shoal & None \\
& Shoreline Impacts & None
\end{tabular}




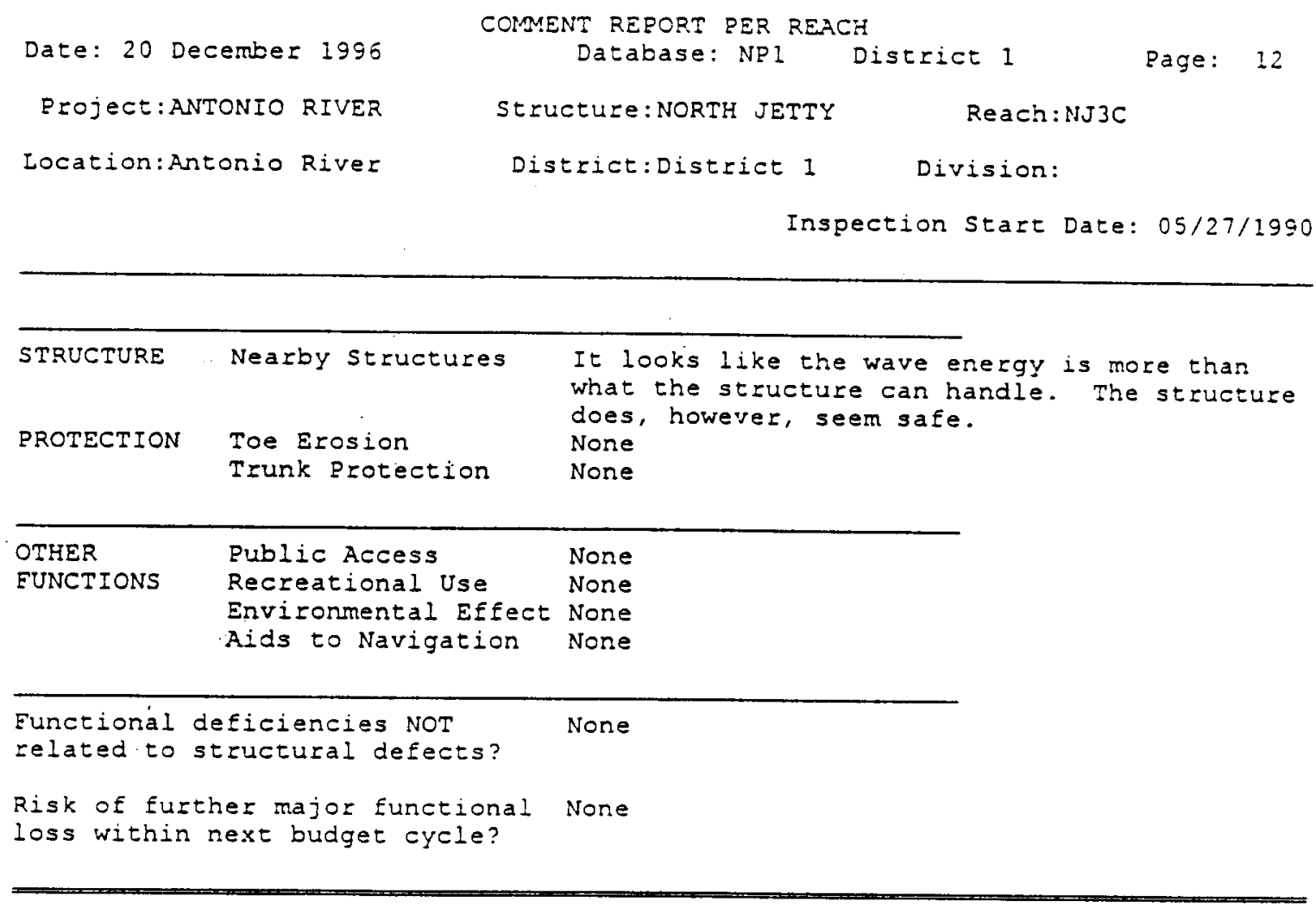




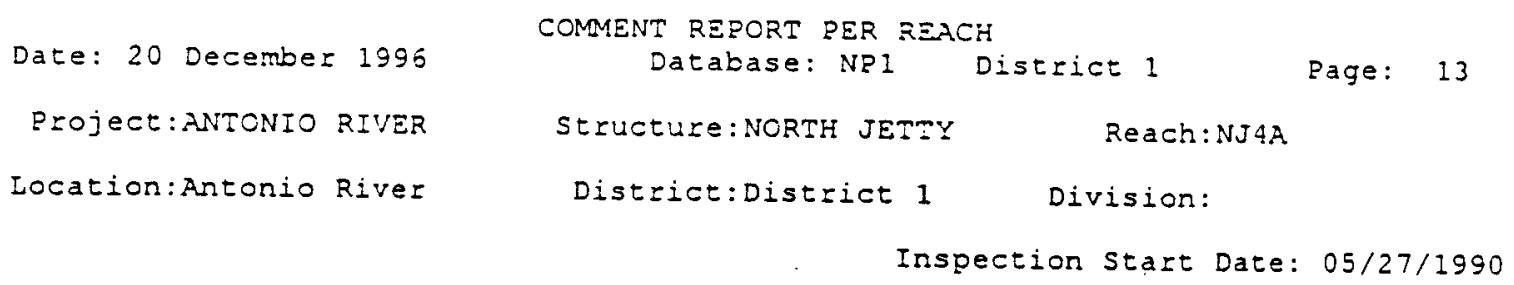

\begin{tabular}{|c|c|c|}
\hline CATEGORY & STRUCTURE DEFICIENCY & COMMENTS \\
\hline CREST/CAP & $\begin{array}{l}\text { Breach/Loss of Crest Elev. } \\
\text { Core Exposure/Loss } \\
\text { Armor Loss } \\
\text { Armor Contact/Interlock } \\
\text { Armor Quality Defects }\end{array}$ & $\begin{array}{l}\text { None } \\
\text { None } \\
\text { None } \\
\text { None } \\
\text { None }\end{array}$ \\
\hline $\begin{array}{l}\text { SEASIDE/ } \\
\text { HEAD }\end{array}$ & $\begin{array}{l}\text { Core Exposure/Loss } \\
\text { Armor Loss } \\
\text { Armor Contact/Interlock } \\
\text { Armor Quality Defects } \\
\text { Slope Defects }\end{array}$ & $\begin{array}{l}\text { None } \\
\text { None } \\
\text { None } \\
\text { None } \\
\text { None }\end{array}$ \\
\hline $\begin{array}{l}\text { CHANNEL/ } \\
\text { HARBOR }\end{array}$ & $\begin{array}{l}\text { Core Exposure/Loss } \\
\text { Armor Loss } \\
\text { Armor Contact/Interlock } \\
\text { Armor Quality Defects } \\
\text { Slope Defects }\end{array}$ & $\begin{array}{l}\text { None } \\
\text { None } \\
\text { None } \\
\text { None } \\
\text { None }\end{array}$ \\
\hline
\end{tabular}

Part B: Functional Comments

\begin{tabular}{lll} 
FUNCTION & DEFICIENCY & COMMENTS \\
\hline \hline HARBOR AREA & $\begin{array}{l}\text { Harbor Use } \\
\text { a.Moored Vessels } \\
\text { b.Harbor Structure } \\
\text { C.Other Facilities }\end{array}$ & $\begin{array}{l}\text { None } \\
\text { None } \\
\text { None } \\
\text { None }\end{array}$ \\
\hline NAVIGATION & Entrance Use & None \\
CHANNEL & Channel & None \\
& & \\
\hline SEDIMENT & Ebb Shoal & None \\
MANAGEMENT & Elood Shoal & None \\
& Harbor Shoal & None \\
& Shoreline Impacts & None
\end{tabular}




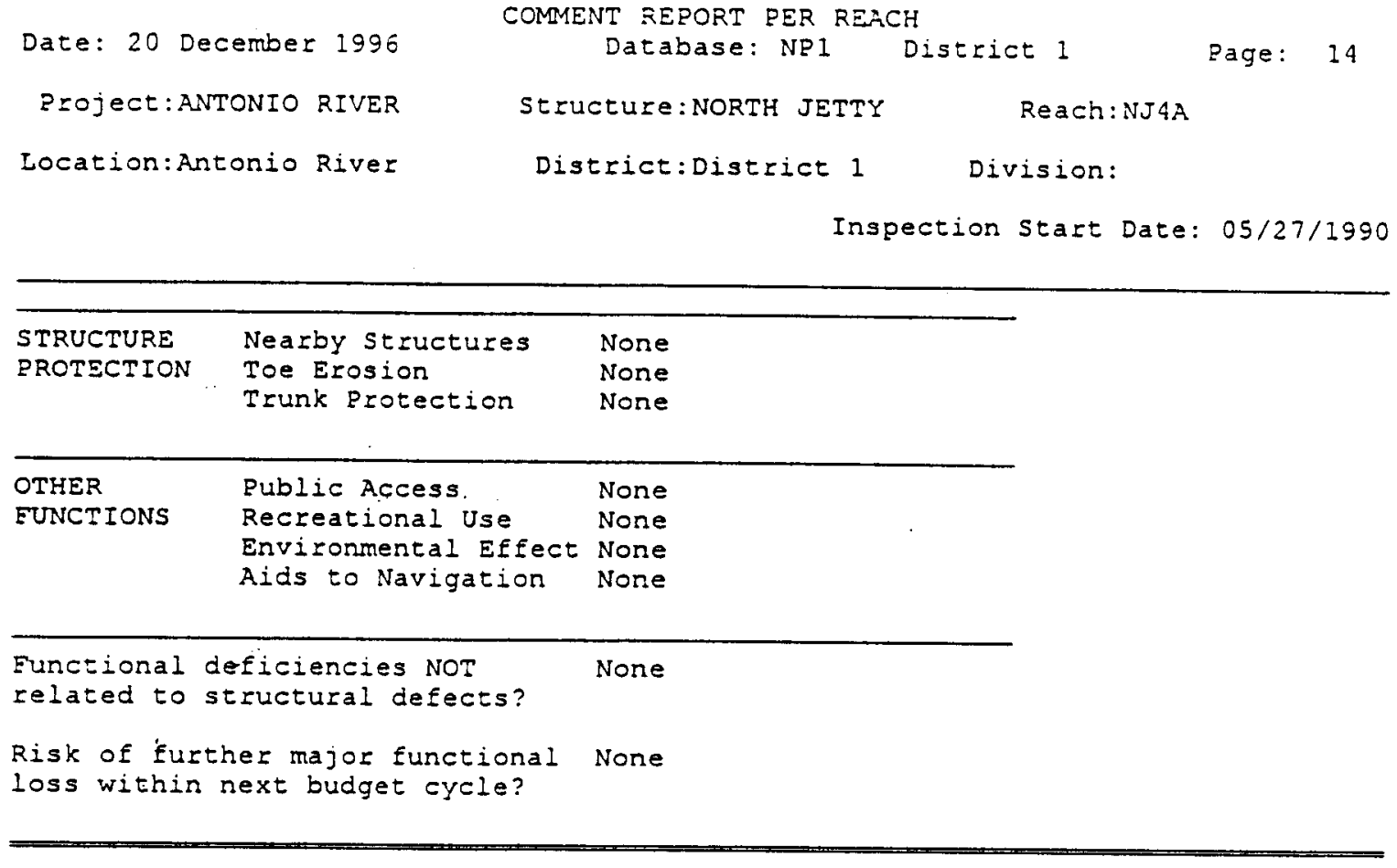




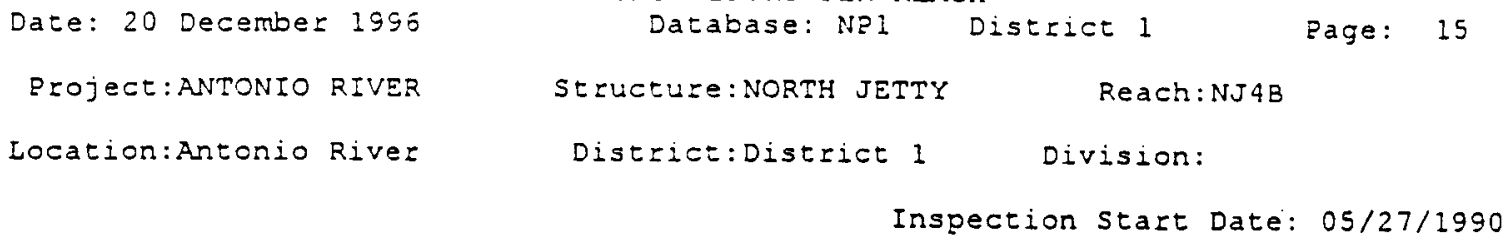

Part A: Structural Comments

\begin{tabular}{lll} 
CATEGORY & STRUCTURE DEEICIENCY & COMMENTS \\
\hline CREST/CAP & Breach/Loss of Crest Elev. & None \\
& Core Exposure/Loss & None \\
& Armor Loss & None \\
& Armor Contact/Interlock & None \\
& None \\
\hline SEASIDE/ & Core Exposure/Loss & None \\
HEAD & Armor Loss & None \\
& Armor Contact/Interlock & None \\
& Armor Quality Defects & None \\
& Slope Defects & None \\
\hline CHANNEL/ Core Exposure/Loss & None \\
HARBOR & Armor Loss & None \\
& Armor Contact/Interlock & None \\
& Armor Quality Defects & None \\
& Slope Defects & None \\
\hline
\end{tabular}

Part B: Functional Comments

\begin{tabular}{lll} 
FUNCTION & DEFICIENCY & COMMENTS \\
\hline \hline HARBOR AREA & $\begin{array}{l}\text { Harbor Use } \\
\text { a.Moored Vessels } \\
\text { b.Harbor Structure } \\
\text { C.Other Eacilities }\end{array}$ & $\begin{array}{l}\text { None } \\
\text { None } \\
\text { None } \\
\text { None }\end{array}$ \\
\hline NAVIGATION & Entrance Use & None \\
CHANNEL & Channel & None \\
& & \\
\hline SEDIMENT & Ebb Shoal & None \\
MANAGEMENT & Flood Shoal & None \\
& Harbor Shoal & None \\
& Shoreline Impacts & None
\end{tabular}


Date: 20 December 1996

Project:ANTONIO RIVER

Location:Antonio River
COMMENT REPORT PER REACH

$$
\text { Database: NP1 }
$$

District 1

Page: 16

Structure:NORTH JETTY

Reach: NJ4B

District:District 1

Division:

Inspection Start Date: 05/27/1990

\begin{tabular}{lll}
\hline STRUCTURE & $\begin{array}{l}\text { Nearby structures } \\
\text { Toe Erosion } \\
\text { Trunk Protection }\end{array}$ & $\begin{array}{l}\text { None } \\
\text { None } \\
\text { None }\end{array}$ \\
\hline OTHER & $\begin{array}{l}\text { Public Access } \\
\text { Recreational Use } \\
\text { Environmental Effect } \\
\text { Aids to Navigation }\end{array}$ & $\begin{array}{c}\text { None } \\
\text { None }\end{array}$ \\
& & \\
\hline $\begin{array}{c}\text { Functional deficiencies NoT } \\
\text { related to structural defects? }\end{array}$ & None \\
Risk of further major functional & None \\
loss within next budget cycle? &
\end{tabular}




$\begin{array}{lccc}\text { Date: } 20 \text { December } 1995 & \text { COMMENT REPORT PER REACH } & & \\ \text { Project:ANTONIO RIVER } & \text { Database: NPI } & \text { District } 1 & \text { Page: } \\ \text { Location:Anconio River } & \text { District:District } 17 & \text { Division: } \\ & & \text { Inspection Start Date: } 05 / 27 / 1990\end{array}$

\begin{tabular}{lll} 
Part A: Structural Comments & \\
CATEGORY & STRUCTURE DEFICIENCY & COMMENTS \\
\hline CREST/CAP & Breach/Loss of Crest Elev. & None \\
& Core Exposure/Loss & None \\
& Armor Loss & None \\
& Armor Contact/Interlock & None \\
& Armor Quality Defects & None \\
\hline SEASIDE/ & Core Exposure/Loss & None \\
HEAD & Armor LOss & None \\
& Armor Contact/Interlock & None \\
& Armor Quality Defects & None \\
& Slope Defects & None \\
\hline CLANNEL/ & Core Exposure/Loss & None \\
HARBOR & Armor Loss & None \\
& Armor Contact/Interlock & None \\
& Armor Quality Defects & None \\
& Slope Defects & None \\
\hline
\end{tabular}

Part B: Functional Comments

\begin{tabular}{lll} 
FUNCTION & DEEICIENCY & COMMENTS \\
\hline HARBOR AREA & $\begin{array}{l}\text { Harbor Use } \\
\text { a.MOOred Vessels } \\
\text { b.Harbor Structure } \\
\text { c.Other Facilities }\end{array}$ & $\begin{array}{l}\text { None } \\
\text { None } \\
\text { None }\end{array}$ \\
\hline NAVIGATION & Entrance Use & None \\
CHANNEL & Channel & None \\
& & \\
\hline SEDIMENT & Ebb Shoal & None \\
MANAGEMENT & Flood Shoal & None \\
& Harbor Shoal & None \\
& Shoreline Impacts & None
\end{tabular}




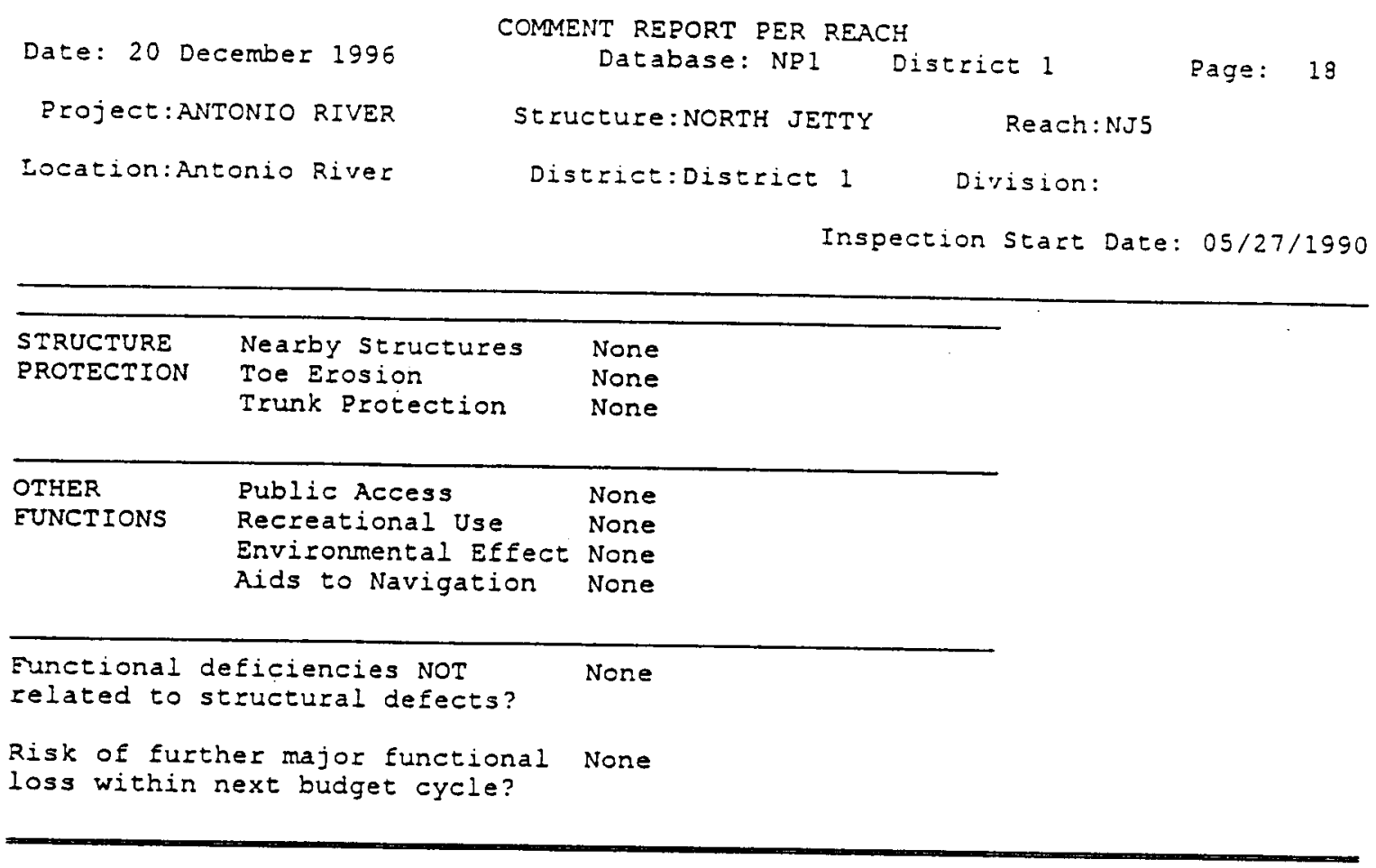


Missing Information Report 


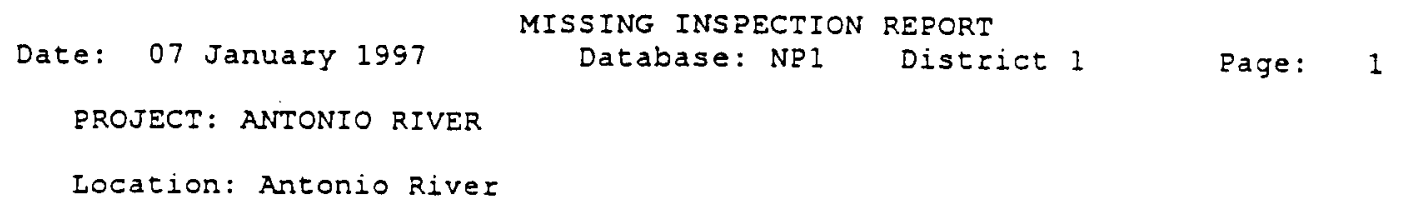

\begin{tabular}{l|ll} 
Project & $\begin{array}{l}\text { Start } \\
02 t e\end{array}$ & Reach Item(s) Missing \\
\hline ANTONIO NORTH JETTY & $05 / 1990$ & NJI None \\
$05 / 1990$ & NJ2A None \\
$05 / 1990$ & NJ2B None \\
$05 / 1990$ & NJ3A None \\
$05 / 1990$ & NJ3B None \\
$05 / 1990$ & NJ3C None \\
$05 / 1990$ & NJ4A None \\
$05 / 1990$ & NJ4B None \\
$05 / 1990$ & NJ5 None
\end{tabular}




\section{Appendix B: Forms}

Blank Inspection Form

Reach Selected Inspection Form 


\section{Blank Inspection Form}




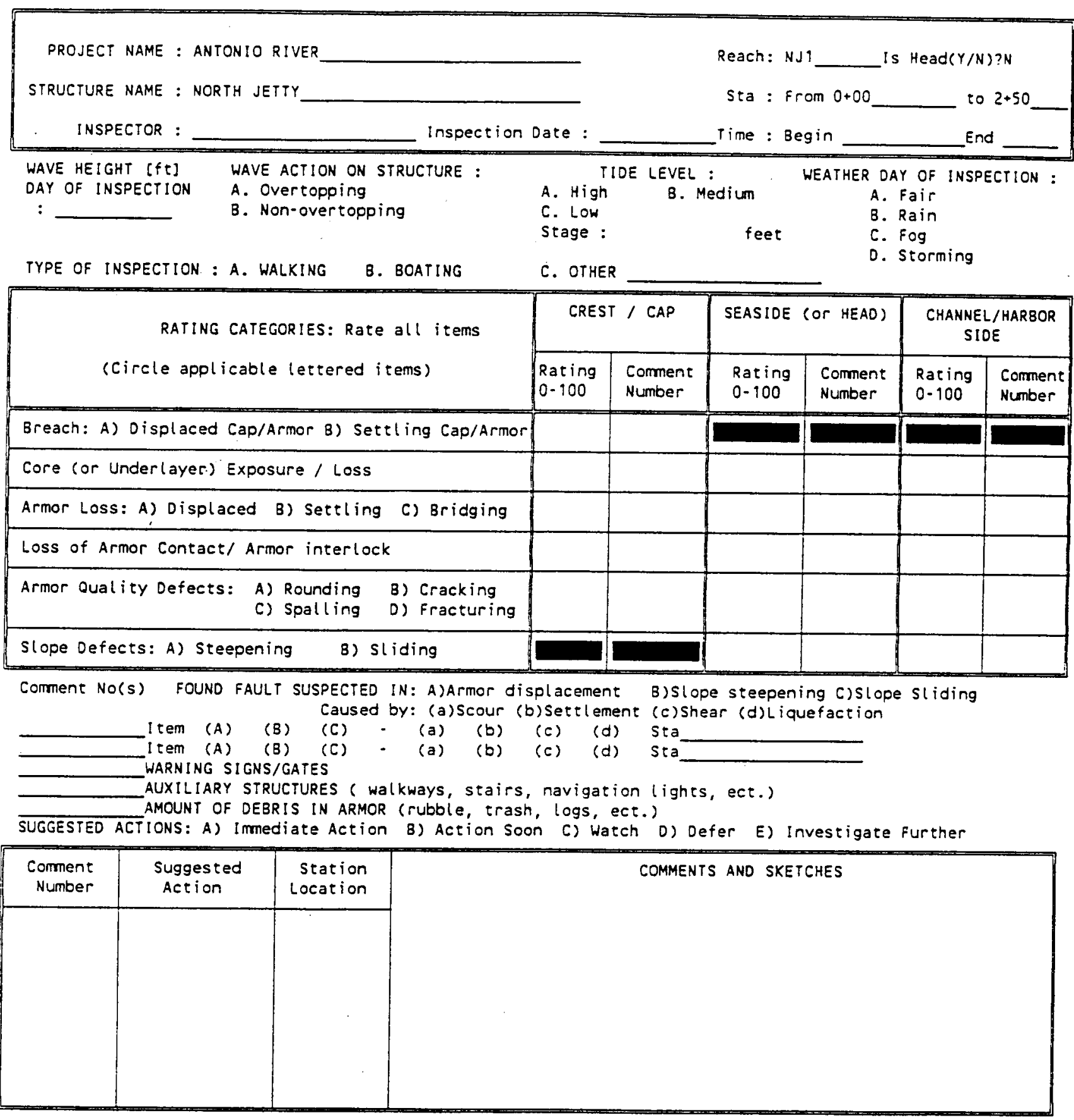


STRUCTURAL RATING FOR RUBBLE BREAKWATERS ANO JETTIES(Continued)

SUGGESTEO ACTIONS: A) Immediate ACtion B) ACtion SOon C) Watch D) Defer E) Investigate Further

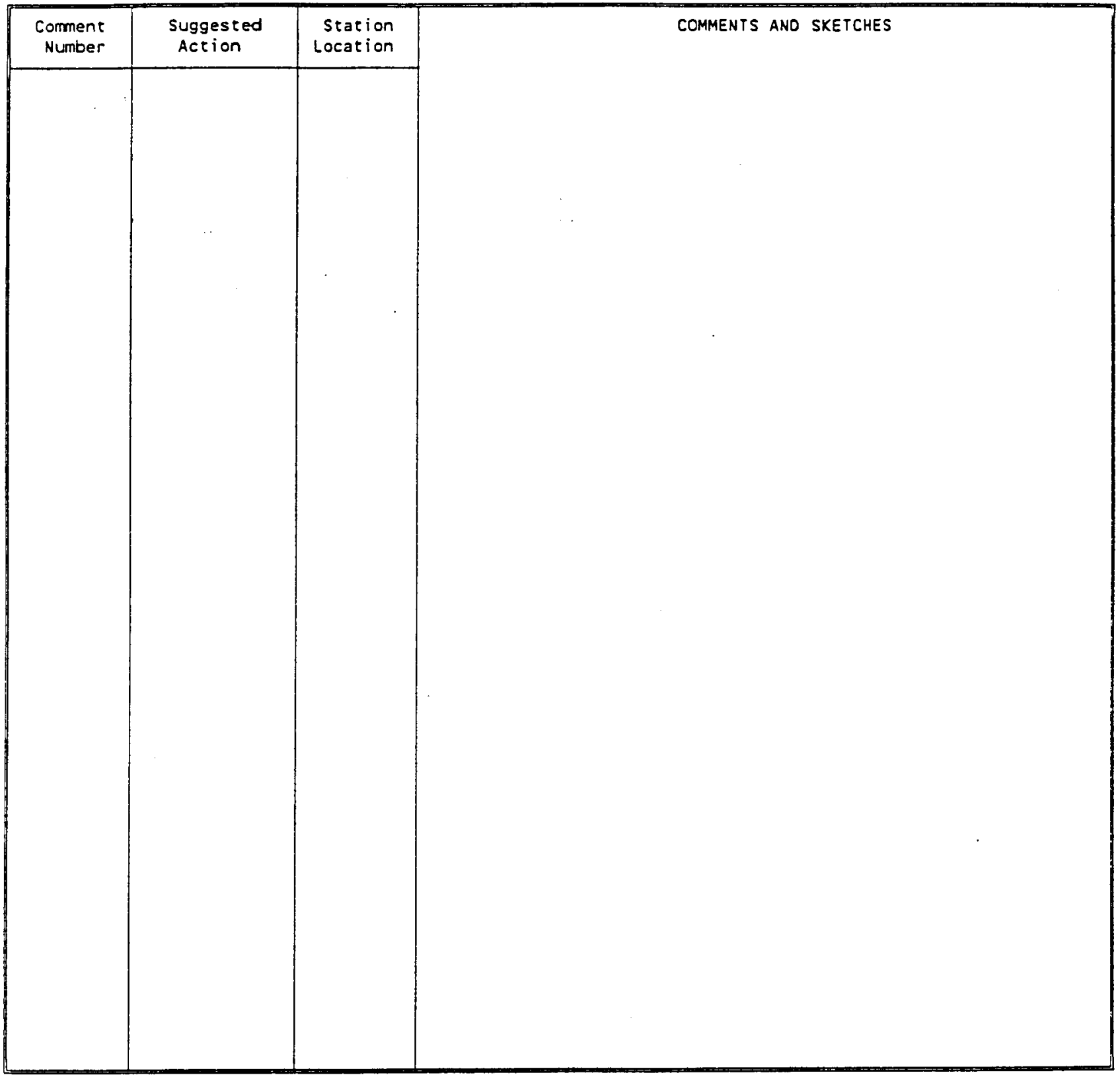




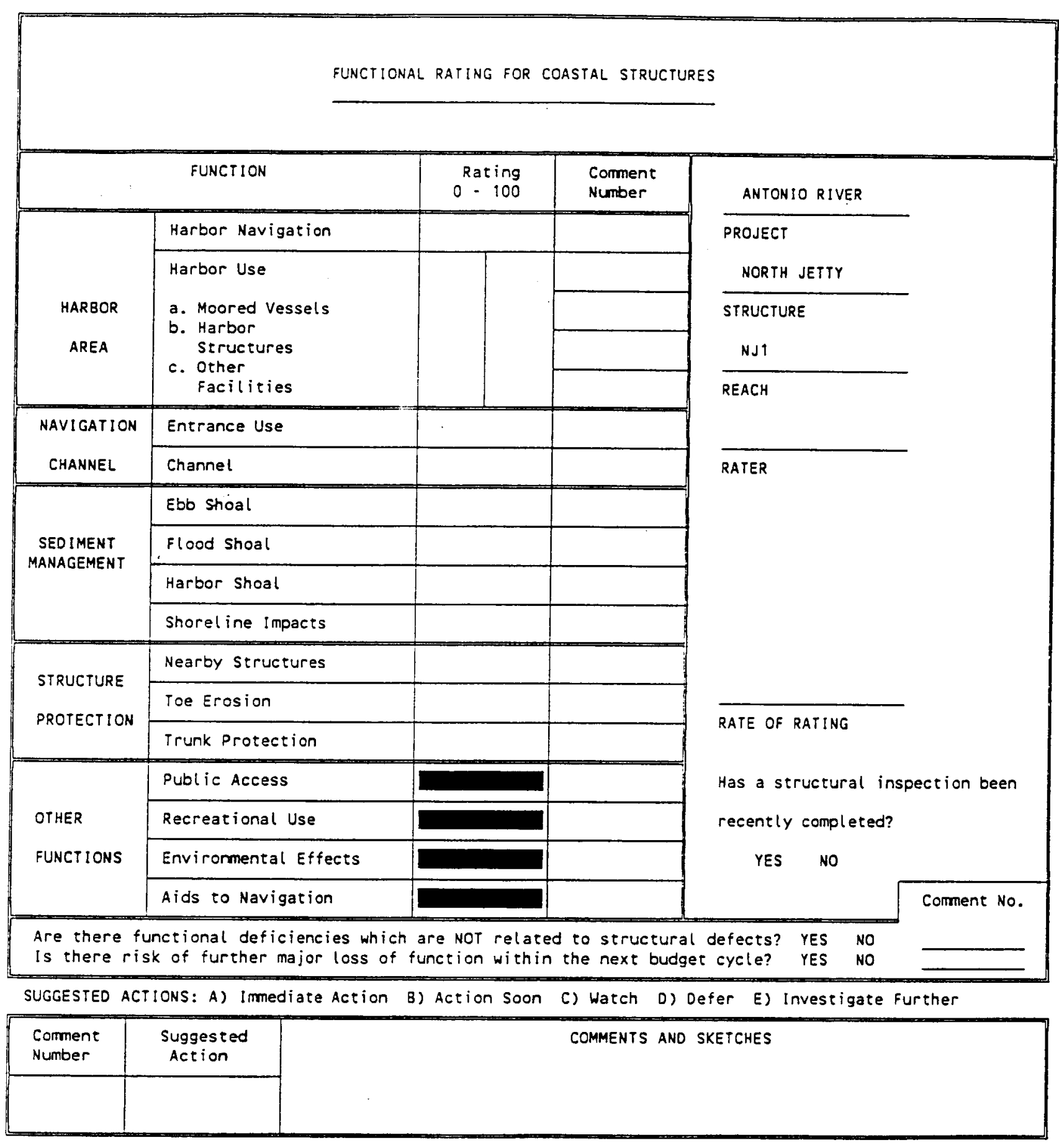


FUNCTIONAL RATING FOR COASTAL STRUCTURES

SUGGESTED ACTIONS: A) (mmediate ACtion B) ACtion Soon C) Watch D) Defer E) (nvestigate further

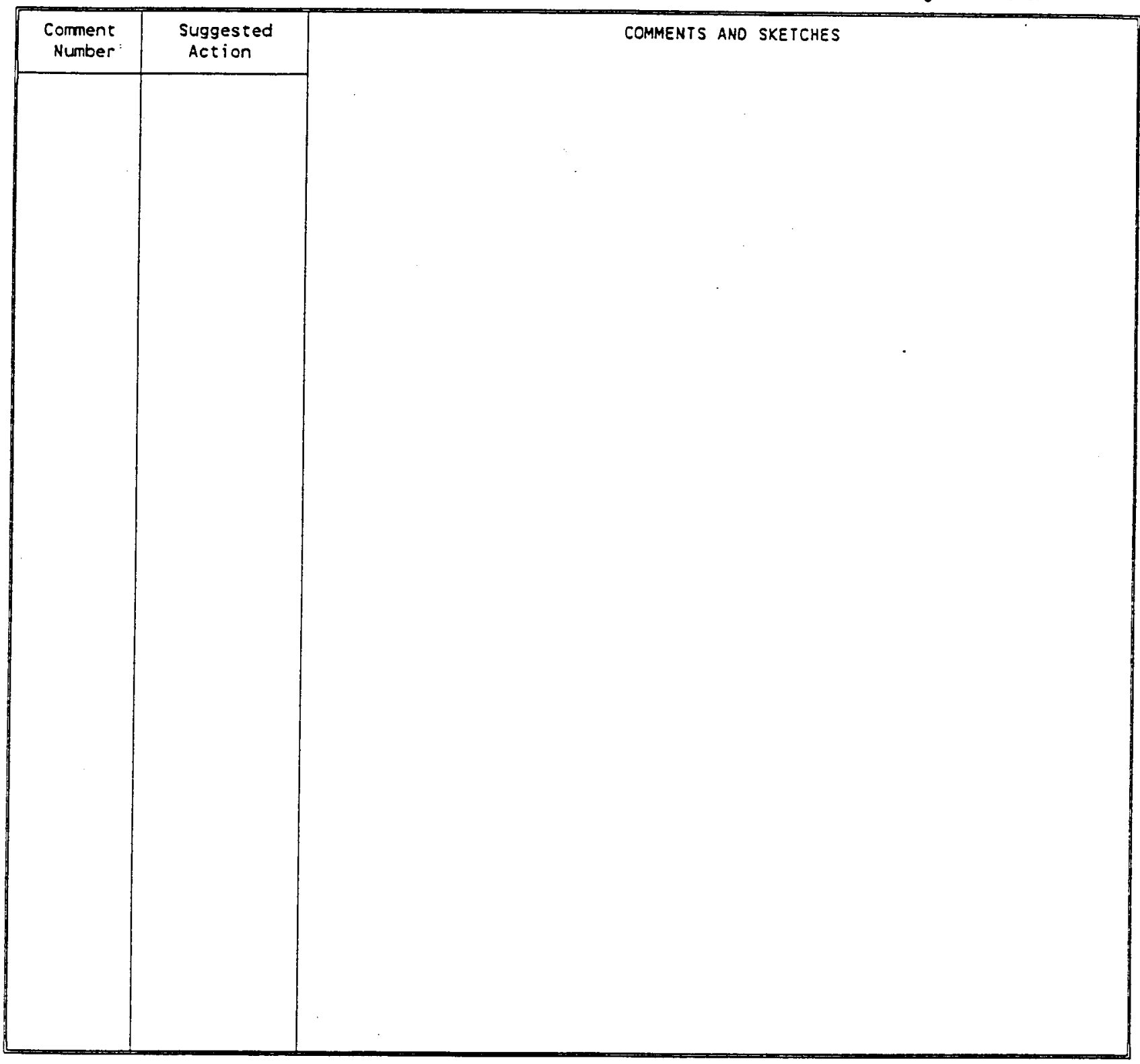




\section{Reach Selected Inspection Form}



of

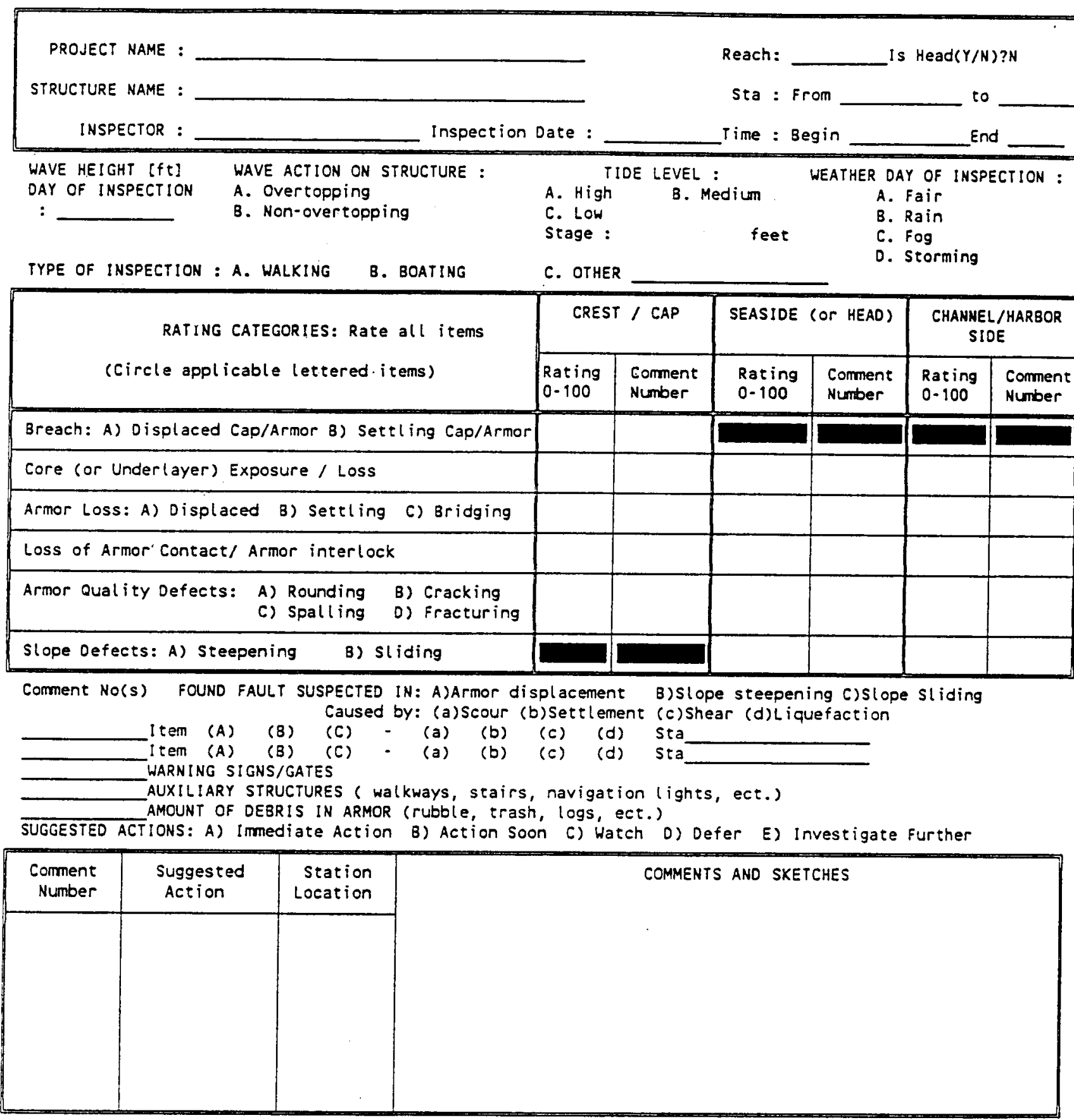


STRUCTURAL RATING FOR RUBBLE BREAKWATERS AND JETTIES(Continued)

SUGGESTED ACTIONS: A) Immediate Action B) ACtion Soon C) Watch D) Defer E) Investigate further

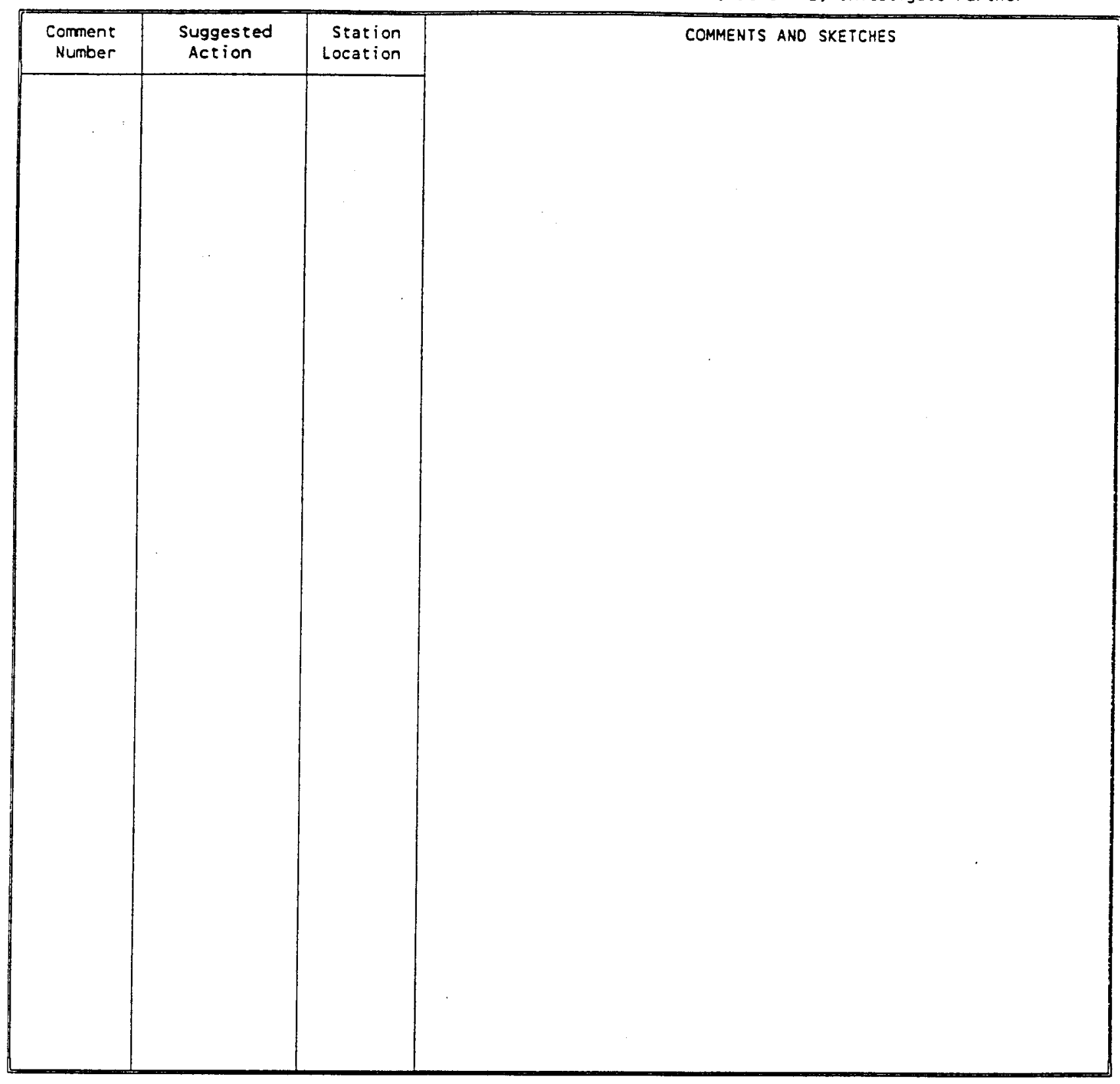




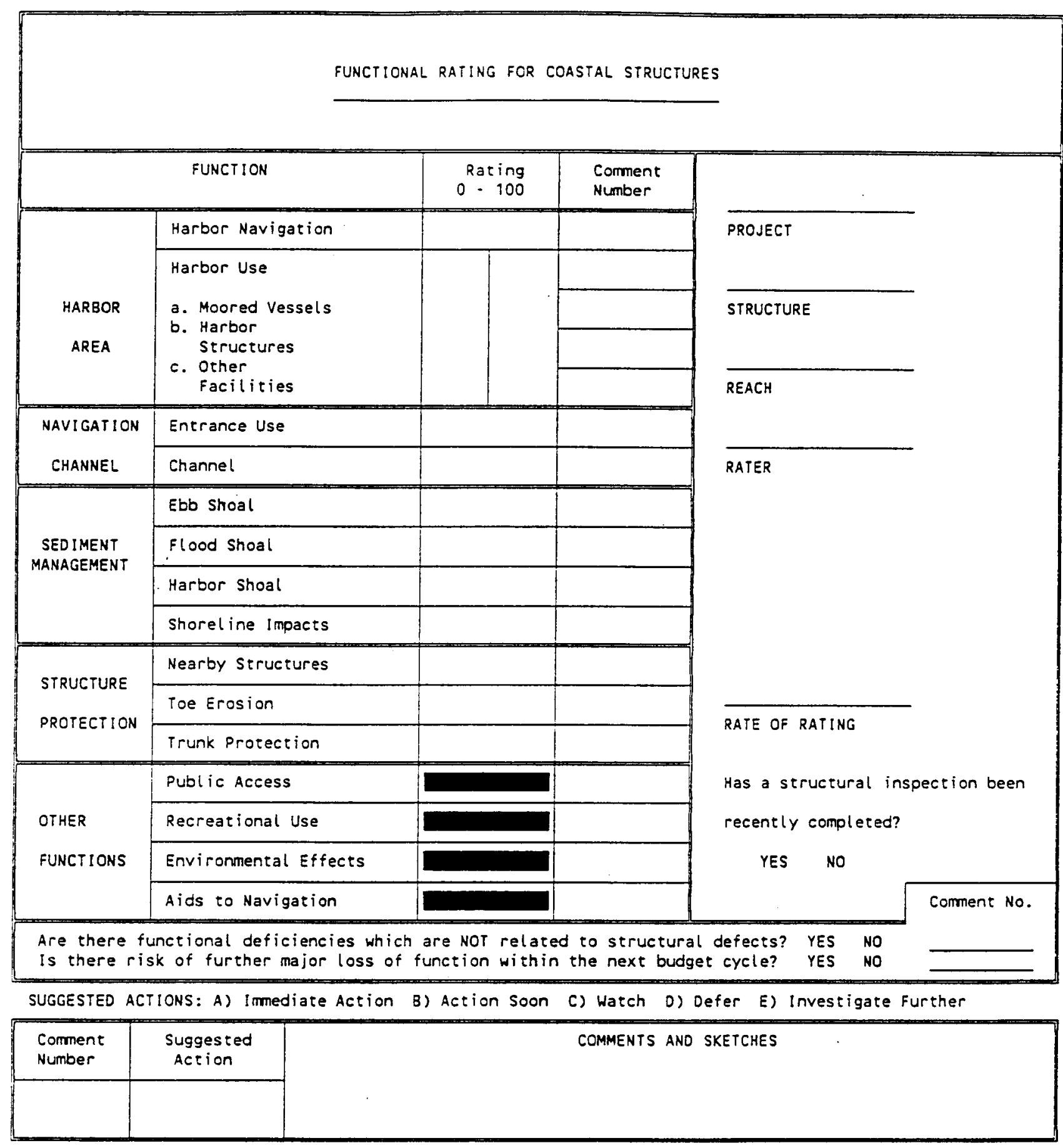


FUNCTIONAL RATING FOR COASTAL STRUCTURES

SUGGESTED ACTIONS: A) Immediate Action B) Action Soon C) Watch D) Defer E) Investigate Further

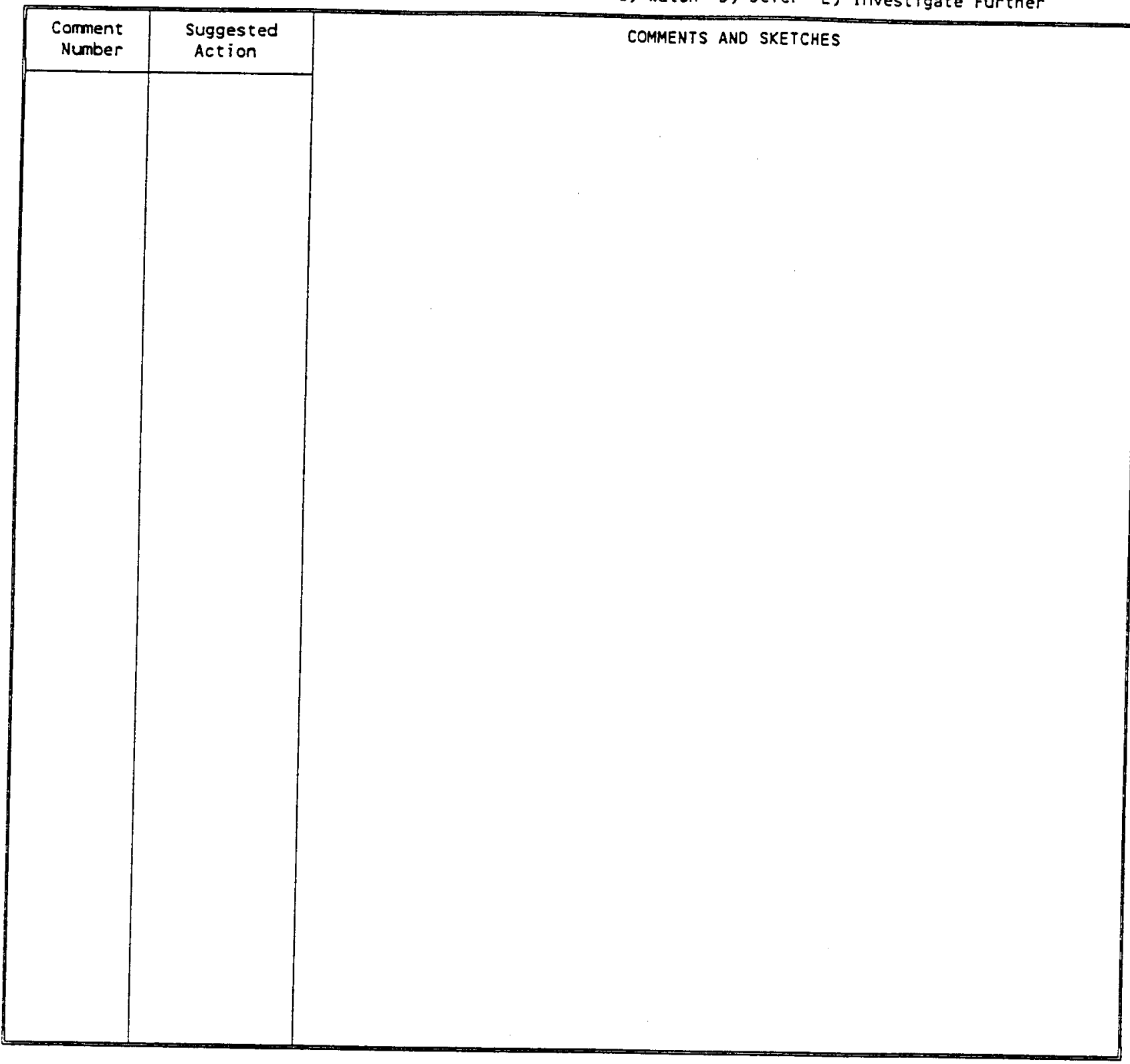

